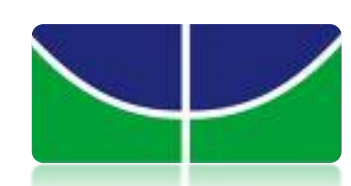

UNIVERSIDADE DE BRASÍLIA

INSTITUTO DE ARTES

PROGRAMA DE PÓS-GRADUAÇÃO EM ARTES

GIL Roberto Gomes de AlmeidA

\title{
diferença voz glossolalia artaud performance
}


Gil Roberto Gomes DE AlmeidA

\section{diferença voz glossolalia artaud performance}

Dissertação apresentada ao Programa de Pós-Graduação em Artes da Universidade de Brasília como requisito para a obtenção do título de Mestre em Artes .

Orientador: Dr. César Lignelli

Brasília, abril 2015. 


\section{Ficha Catalográfica}

Almeida, Gil

diferença voz glossolalia artaud performance/ Gil Roberto Gomes de Almeida. Brasília [S.n], 2015.

$146 \mathrm{f}$.

Dissertação de mestrado, Universidade de Brasília, Instituto de Artes.

1. Voz. Glossolalia. Artaud. Performance. I. Título. 
Dissertação de Mestrado em Artes apresentada a:

Prof. Dr. César Lignelli (CEN/UnB)

Orientador

Profa. Dra. Sulian Vieira Pacheco (CEN/UnB)

Membro Externo

Profa. Dra. Roberta Kumasaka Matsumoto (CEN/UnB)

Membro Efetivo

Profa. Dra. Alice Stefania Curi (CEN/UnB)

Membro Suplente

Vista e permitida à impressão.

Brasília-DF, 26 de março de 2015. 
À memória de todos os vivos mortos cujas vozes aqui ressoam. 


\section{Agradecimentos}

Ao César, meu orientador, cuja amizade tornou possível o amor, a sutileza e a intensidade presentes nesse trabalho.

Ao Astor Braz pelas conversas amorais e a escuta sem preconceitos.

A Isa pelas estranhezas peculiares ao exercício de sua alteridade.

A Juliana e Isabella pelo carinho e pela escuta sensível.

Às professoras Sulian e Roberta cujas considerações relevantes tornaram possível a porosidade e a reconfiguração desse trabalho.

A uma legião de pessoas aqui presentes por terem passado por mim. 
"Nonada."

Guimarães Rosa 


\section{Resumo}

A partir da obra de Artaud, sobretudo do período de internação em Rodez (fevereiro de 1943 a maio de 1946) até a sua morte (março de 1948), evidencia-se um ideário que sugere princípios para uma vocalidade no contexto da performance. Esta vocalidade é baseada em uma noção de glossolalia enquanto conceito vinculado às práticas enunciativas, sobretudo como potência para desarrazoar estratos vocais. Assim, a glossolalia pode agregar valores sonoro-poéticos que desestabilizam aspectos mais estabelecidos da produção e percepção de sentidos relacionados à voz e, dessa forma, busca-se aqui uma discussão sobre possíveis fronteiras da produção vocal para a performance ao valorizar aspectos nômades em sua experimentação de forma a enriquecer a investigação do ator e do performer contemporâneo. A experimentação no contexto dessa pesquisa baseou-se num conjunto de práticas de improvisação que, embora não tenha se abdicado da palavra, sobretudo em sua criação imaginária que extrapola o contexto da língua, buscou priorizar o som e seus parâmetros vinculados a aspectos mais ruidosos, ininteligíveis e instáveis da produção vocal, apontando recursos para um aquém e um além da linguagem. Dessa forma, buscando uma ressonância de Artaud em Deleuze e Guattari, assim como em Derrida, um plano conceitual foi traçado como agenciador de processos de criação para a voz em performance. Demais, foi feito um recorte cartográfico da glossolalia nos contextos linguístico-psiquiátrico, religioso e artístico que também serviu de território histórico-conceitual. Dois exercícios estéticos, baseados em práticas glossolálicas, foram gravados e editados em arquivos de áudio e cartografados a partir de uma noção de parâmetros do som, possibilitando a discussão para uma poética do devir vocal em performance.

Palavras-chave: voz, glossolalia, Artaud, performance. 


\begin{abstract}
Hailing from the works of Artaud, especially during his stay at Rodez (February 1943 to May 1946) until his death (March 1948), it is evident a set of ideas that suggests principles for voicing in the context of performance. This vocality is based on a notion of glossolalia as a concept linked to enunciative practices, especially as a power to irrationalize vocal strata. Thus, glossolalia can add sound-poetic values that destabilize more established aspects of production and senses of perception related to voice and, thus, here we seek a discussion of possible boundaries in vocal production to performance by highlighting nomad aspects in its experimentation, in order to enrich an actor and contemporary performer's research. Experimentation in the context of this research was based on a set of improvisational practices which, although not having abdicated the word, especially in its imaginary creation that goes beyond the language context, sought to prioritize the sound and its parameters linked to noisier aspects, unintelligible and unstable voice production, pointing to a resource below and beyond language. This way, seeking an Artaud resonance in Deleuze and Guattari, as in Derrida, a conceptual plan was drafted as an agent of creation processes for vocal performance. Also, there is a cartographic clipping of glossolalia in linguisticpsychiatric, religious and artistic contexts that also served as a historical and conceptual territory. Two aesthetic exercises, based on glossolalic practices, were recorded and edited and mapped from a notion of sound parameters, allowing the discussion into the poetics of becoming in a vocal performance.
\end{abstract}

Keywords: voice, glossolalia, Artaud, performance. 


\section{Sumário}

abracadabra

qual a diferença entre a voz?

cricriptatore

theatrum vita philargica

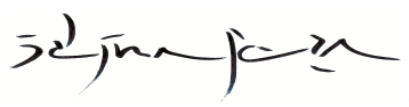

a rangmbde a rangmbde a rouarghambde

antistratosquo.

...babelybablelyblablelyblablabely...

glossololalium.

qual a diferença entre mim?

epifonia

blefarite

abracadabra

referências 


\section{abracadabra}

Um pacto com o diabo, alianças com fronteiras e os desígnios do perigo: em síntese, isto seria o que me impulsionou a fazer esta pesquisa voltada para a investigação da voz em performance, tendo no conceito de glossolalia ${ }^{1}$, o potencial nômade da criação desta vocalidade $^{2}$. O que faz passar a voz? Em que tipo de corpo eu invisto para possibilitar meu desejo na criação artística, na procura de uma voz passível de fazer alianças com o desconhecido? Como fazer da prática e da teoria uma dimensão vital da existência e como criar para si um corpo sem órgãos ${ }^{3}$ que possibilite um uso ético e estético do que me acontece como disse Fuganti ${ }^{4}$ ? Todas estas perguntas atravessam a criação numa busca constante de uma voz desarrazoada, que está sempre reconfigurando estratos. O performer, o pacto, a voz, a glossolalia: é sobre isso, um conjunto de eventos complexos e multiperspectivados, que trata esta pesquisa. Como a glossolalia se aliaria a uma noção para a voz em performance? E se pactuar almeja uma entrega peculiar no investimento de desejo na criação, o que pode a voz num pacto com o diabo?

Muito da discussão sobre o que pode essa voz vai ao encontro de uma noção de entre, uma dimensão fugidia, híbrida, rumorosa: inter-reinos, intermezzo. O que me fez pactuar com uma filosofia do desejo em Gilles Deleuze e Félix Guattari, para quem o diabólico é aqui compreendido como uma prática intensiva, um colocar-se em estado de variação contínua ${ }^{5}$, em devires que se proliferam em zonas de borda. Na experiência de se colocar entre as vagas, entre mundos, evocam-se práticas que emanam cartografias intensivas, cambiantes, num contínuo descentrar-se: um nomadismo como princípio desse movimento. Essas práticas sugerem territórios limítrofes, marginais, embaçados, desconhecidos, indiscerníveis, cujas as impurezas perfazem singularidades na distribuição dos afetos. Comumente não se vê o entre,

\footnotetext{
${ }^{1}$ A glossolalia, enquanto conceito, é tratada na parte

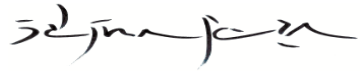

${ }^{2}$ No contexto desta pesquisa o termo vocalidade será utilizado como "as múltiplas formas de produção de voz e palavra implementadas por um grupo humano específico em uma contingência socio-histórica dada" (Davini, 2007:18, tradução nossa).

${ }^{3}$ Conceito discutido por Deleuze e Guattari a partir de Artaud, e desenvolvido na parte 'theatrum vita philargica'.

${ }^{4}$ Luiz Fuganti é filósofo e criador da ONG "Escola Nômade de Filosofia".

${ }^{5}$ Deleuze e Guattari em "Postulados da Linguística", texto de "Mil Platôs" dizem que a figura da variação contínua "é como uma amplitude que não cessa de transpor, por excesso e por falta, o limiar representativo do padrão majoritário" (2002: 53). Aqui, os autores franceses, inferem uma noção de devir, que é sempre minoritário, a exemplo da literatura menor em Kafka. Uma matéria intensa é liberada em prol das metamorfoses que se configuram no ato de experimentar, opondo-se à uma estabilidade invariante. A improvisação no contexto dessa pesquisa vai ao encontro dessa noção de variação contínua.
} 
é difícil tocá-lo, apreendê-lo enquanto forma, ele parece escapar e, ao mesmo tempo, requisita uma participação molecular. Entre uma coisa e outra há o infinito. Até a matemática suscita esta sensação: tomemos o que há entre o número 1 e o número 2. À medida que fracionamos o número $1(1,2,1,22,1,99,1,999,1,99991, \ldots)$ percebemos que não chegaremos nunca à margem do 2, pois a distância ou o tempo parece diluir-se numa molecularidade que aponta para o infinito. Um espaço-tempo cujo os graus de diferenças proliferam-se imperceptivelmente, território indiscernível.

Dessa forma, tatear uma vocalidade glossolálica num contexto artístico, faz sugerir uma noção de performance enquanto terreno instável, abarcando muitas áreas do conhecimento, cujas as intersecções e incertezas povoam o ato criativo. Daí a confluência do performativo, do performático e do teatral, cujas zonas, maculadas pelas influências uns dos outros, tornam tão rica a investigação de uma tal vocalidade.

De maneira geral, optei pelo termo performer, cuja amplitude não exclui o performador, tampouco desconsidera a atividade do ator ${ }^{6}$. Contextualmente poderei me servir de um ou outro termo na conveniência do que desejo agenciar, ao mesmo tempo em que acredito que esta terminologia, aqui ponderada, não busca uma determinação de territórios, mas procura evocar limiares na multiplicidade da criação, que inclui as práticas voltadas para uma vocalidade, assim como os processos de escrita e pesquisa aqui evidenciados. Demais, é a partir de Antonin Artaud, um artista singular cuja obra possibilita uma ampla discussão sobre zonas de fronteira no ato criativo, que uma tal vocalidade é sugerida na força de potenciais cartografias.

Enquanto esteve internado em Rodez, por volta de fevereiro de 1943 a maio de 1946, Artaud enfrentou um profundo embate com a linguagem, com o corpo, com a loucura e com a arte e produziu documentos literários, crítico-filosóficos e tantos outros textos que não conseguem servir às categorias e gêneros que se costuma dar à criação. Esta produção, que incluía cartas, desenhos, poemas e notas, possibilitou a ampliação dos limites e a discussão de linguagens como a da literatura, do teatro e das artes plásticas.

Artaud realmente foi um pensador do aquém e do além das linguagens, sobretudo da dimensão da língua, território de cirurgias e de uma entrega desmedida de seu furor. Ele fez a

\footnotetext{
${ }^{6}$ Ver Marvin Carlson in Performance - Uma introdução crítica (2010).
} 
língua francesa sofrer intervenções, cujas linhas de fuga fizeram sugerir uma noção para a voz em performance. Foi neste contexto que surgiram as primeiras manifestações glossolálicas como extravasamento deste corpo a corpo com a linguagem. Neste mesmo período de intensa produção textual, em que Artaud ousou recriar-se à medida de um corpo sem órgãos, estas manifestações de uma linguagem delirada, excessivamente lúcida, incompreensível, densa de sentidos criativos e filosóficos, fizeram-se passar por ele. Elas atravessaram um longo processo de incubação, de alquimias internas, até sua transubstanciação numa língua poética.

Artaud está presente nesta pesquisa como um outro diluído, em sua dimensão poética e passional. Um outro devorado, mal digerido, muitas vezes regurgitado e constantemente reconfigurado. Uma cartografia que se redimensiona na confluência política do desejo. Ele está aqui por ressonância e reverberação poético-conceitual, por ter experienciado limites que contribuíram para novas perspectivas de se perceber a performance, por sua dedicação aos sentidos e à materialidade da cena, por fazer de seu pensamento-prática uma possibilidade de se pesquisar a voz em seu devir nômade e, acima de tudo, por ter vivido o risco de uma existência voltada para a potência da vitalidade. Por sua torrente criativa e idiossincrasias, sua obra mais sugere que edifica e estratifica. Trilhou caminhos incômodos e terrenos movediços que fizeram do entre uma dimensão intensa de valores subversivos, ora evasivos, ora herméticos, excessivos e contraditórios.

Na obra de Artaud algo requisita ser ouvido, algo suscita uma voz. Um espectro vocal parece povoar seus escritos. Talvez devido aos seus constantes internamentos em clínicas e asilos, ele tenha escrito em demasia aquilo que poderia ser dito ou experimentado no palco. É notável o potencial audível de sua obra, pois quando o lemos temos uma forte impressão de que aquilo que está escrito, pede ansiosamente para ser gritado, forjado na voz e na língua e, não raro, um impulso atroz parece querer explodir de seus escritos e desenhos, fazendo a linguagem inspirar sonoridades. Em uma entrevista, Jacques Derrida comenta este caráter audível do texto artaudiano: "Lê-lo deveria implicar ressuscitar sua voz, lê-lo imaginando-o proferir seus textos. Não conheço outro autor cujo o ato de proferir esteja tão presente em seus textos" (tradução nossa) ${ }^{7}$. Isto significa, também, lê-lo com os ouvidos, apreender uma possível voz no seu discurso. Lê-lo em voz alta também, como recurso a experimentar a leitura. E nesta

\footnotetext{
7 "Leerlo debería implicar resucitar su voz, leerlo imaginándolo proferir sus textos. No conozco otro autor en el que el acto de proferir esté tan presente em sus textos". Jacques Derrida, Las voces de Artaud, entrevista com Ėvelyne Grossman, in Magazine Littéraire, num. 434, 2004. Consultado in http://www.egs.edu/faculty/jacquesderrida/articles/las-voces-de-artaud/.
} 
necessidade vital e cruel de dizer, de proferir o verbo para realizá-lo na matéria, Artaud vai operar um conflito que, transbordando a língua, vai desaguar na glossolalia.

Essa linguagem inventada por Artaud parece fazer a língua vibrar em outro estado de expressão, que é a manifestação vocal e suas possibilidades enquanto som. Sua glossolalia é uma investigação enquanto escrita e, sobretudo, enquanto voz. Não se trata aqui de uma linguagem dos anjos como na acepção cristã, ele não é veículo de uma voz divina, mas sim aquele que engendra sua própria língua e a faz fugir do julgo das normas linguísticas e da lógica dos discursos. É uma voz que procura dizer-se a si mesma. Uma voz cujas sílabas são escandidas pelo desejo de recriar-se como artista e como pessoa.

Procuramos constantemente dar significado e sentido a tudo. Isto é cultural, saudável, diria até vital. Trata-se de uma necessidade de situar-se em relação às coisas e aos acontecimentos, relaciona-se, de alguma forma, à linguagem e sua construção de mundo. Ao mesmo tempo, a percepção e a produção de sentidos torna-se complexa nos entres e, na sua relação com fronteiras e limiares tornam-se singularidades cujos afetos participam de uma lógica peculiar. Uma vibração do sensível nos faz participar do mundo, ou seja, somos acontecimento, somos mundo, antes mesmo de construí-lo. Soa como a experiência que não pode ser descrita em palavras, pois ao nomeá-la, pode-se perder seu sentido. A glossolalia insinua-se, assim, como um contrassenso ao logos, ousa uma manobra enunciativa que muitas vezes não almeja dizer nada, escapa às explicações e faz multiplicar os sentidos e, por isso, pactua com o excesso.

Como enunciação vocal, ela possibilita o aquém e o além dos significados, ela comporta a sujeira para fora dos discursos, ousa uma anarquia sonora na voz e dá lugar ao som com valor intrínseco a si mesmo. É resto e excesso. Quando se fala da voz como resto e excesso pergunta-se: resto e excesso de quê? Parte de uma noção de voz como resto e excesso é sugerida por Slavoj Zizek em seu artigo 'La voz en la diferencia sexual'(1997) ${ }^{8}$. Recorrendo a Lacan ele fala de um excesso vocal que faz romper as amarras da significação para precipitarse no gozo de si, tão como recorre a uma economia libidinal como resto sem significação. $\mathrm{Na}$ verdade, essa voz suscita os perigos de um gozo que experimenta o excesso contra um logos de uma vocalidade formal. Uma questão de gênero é perpassada pelos estratos de tais vocalidades, fazendo ecoar uma noção estruturalista do inconsciente com funções

\footnotetext{
${ }^{8}$ Texto consultado no site www.con-versiones.com/nota0810.htm.
} 
determinadas à uma voz paternal, masculina e outra ao aspecto feminino. Ao mesmo tempo, esta noção é filha dileta de uma psicanálise lacaniana, cuja abertura possibilita algumas reflexões sobre uma voz glossolálica, mas cujos limites impossibilitam sua progressão. Algo ainda suscita desdobramentos: resto e excesso de quê?

O estudo da glossolalia como aspecto nômade das instituições da voz e da língua vai ao encontro de reflexões a essa pergunta, justamente por comportar um conjunto de características e práticas que podem agregar valores para a voz em performance. Jean-Jacques Courtine também analisa o caráter de resto na noção de glossolalia: "A glossolalia é excesso, transbordamento ao mesmo tempo das estruturas da língua e do revestimento do corpo [...] Experiência, para o sujeito falante, de um limite da linguagem e do corpo" (2006: 27, tradução nossa) ${ }^{9}$, dessa forma, a despeito de transbordar determinados limites da língua, a glossolalia também se serve, em diversos contextos, da linguagem, sobretudo em seu aspecto semântico, demais, anuncia a experiência de que o corpo produz som vocal e ele faz reverberar a matéria, o que implica dizer que além do acontecimento corpóreo na enunciação $^{10}$, ela também corporifica a linguagem. Ou seja, a glossolalia produz intensidades, assim como agencia semióticas, aqui entendida como diversos regimes de signos. Manifestase como um ideograma sonoro, carregada de muitos sentidos e imagens auditivas.

Nesta perspectiva, Deleuze e Guattari, partindo das teses do britânico John Langshaw Austin, observam os pressupostos implícitos ou não discursivos da linguagem como um território possível de variação contínua afeto à experimentação, abrindo uma discussão para aquilo que, não se confundindo com a linguagem, e sendo inclusive 'o' exterior dela, participa do mesmo plano da construção de sentido. Esta noção de um 'fora' da linguagem terá grande importância na discussão sobre uma glossolalia que se evidenciou no meio artístico durante o século XX como transgressão linguística e experimentação do som.

\footnotetext{
9 "La glossolalie est excès, débordement tout à la fois des structures de la langue et de l'enveloppe hermétique du corps [...] Expérience, pour le sujet parlant, d'une limite du langage et du corps". In 'Les silences de la voix', Ecole thématique/Université d'été <Histoire des représentations de l'origine du langage et des langues $>$, Ile de Porquerolles, Var, (août-semptembre 2006). Consultado em http://htl.linguist.univ-parisdiderot.fr/biennale/et06/texte\%20intervenant/pdf/courtine.pdf.

${ }^{10}$ A noção de glossolalia aqui tratada insere-se no campo das práticas enunciativas, voltado para a expressão e manifestação de um dizer, de um falar, em sua diversidade e seus princípios como uso da vida. Aproxima-se da pragmática de Deleuze e Guattari e do conceito de agenciamento coletivo de enunciação. Pois considera-se que não existe sujeito de enunciação, tampouco enunciado individual. Isto transporta a glossolalia para o contexto múltiplo do discurso indireto livre, cuja polifonia de vozes faz marulhar uma coletividade que enuncia. A glossolalia seria uma espécie de enunciação sem enunciado.
} 
Contemplando estas reflexões, Artaud se inscreve aqui como um pensador que muito pode agregar à pesquisa da produção sonoro-vocal para o ator e performer contemporâneo. Seu poder de sugestão e sua instância poética dão margem a muitas produções de sentidos sensórios, filosóficos, poéticos, enfim, e possibilitam investigações múltiplas sobre o ato criativo, como é o caso da noção de corpo sem órgãos, inferida por Deleuze e Guattari ou a noção de subjétil em Derrida, estruturada a partir de uma reflexão sobre as pictografias nos últimos escritos de Artaud. O teatro pretendido por ele apelava aos sentidos do ator e do espectador por uma crueldade ${ }^{11}$ lancinante capaz de demover as emoções a partir da dimensão sensível. Dessa forma, o som e, sobretudo, a voz como um de seus aspectos, aparece em sua obra de maneira idiossincrática, ruidosa, num apelo constante a uma possível sonoridade que não se sedimenta, nem se estabelece, mas se reconfigura numa agonia que alimenta sua própria vida.

Sua obra é vasta e acompanhou as contradições de um constante refazer-se, que incluiu longos períodos de internações. Diante de um terreno tão híbrido e raramente delimitado, Artaud povoa esta pesquisa sobretudo em razão de sua potência sugestiva e de sua pulsão. Seus conteúdos são díspares, mutáveis, inconstantes, diante da insustentabilidade de sua posição como aponta Susan Sontag (1986). Seus escritos suportam conteúdos obscuros e de difícil digestão, não se recorre a eles para uma segurança, mas somos afetados diante de sua dimensão poética, que faz ressoar algum desconforto e instabilidade: "Pode-se ser inspirado por Artaud. Pode-se ser chamuscado, mudado por Artaud. Mas não há maneira de aplicar Artaud" (Sontag, 1986: 56). Dessa forma, uma vocalidade possível em Artaud percorre uma cartografia singular, experimental, torta, aberta e fugidia. Ela perpassa toda sua vida, mas é durante seu longo período de internação, passando por sua liberdade até sua morte, que tal vocalidade glossolálica terá uma dimensão acústica enquanto poética sugerida.

A voz é perpassada por componentes culturais, serve à língua, comunica, discursa, dialoga, oratória, eloquência, edifica territórios, modos, relaciona-se intimamente com as palavras, corrobora com tradições do dizer, do vocalizar, e comporta uma ampla abertura para zonas pouco exploradas, podendo se servir de um potencial nômade para além do discurso linguístico. Dessa forma, um impulso glossolálico pode servir à investigação para a cena de forma a produzir outros sentidos e possibilitar inusitadas reflexões.

\footnotetext{
${ }^{11}$ A crueldade, conceito afirmativo em Artaud, tem alguns desdobramentos em 'theatrum vita philargica'.
} 
Este impulso outro se vale de uma dimensão material das potências vocais que dialoga com os sentidos em presença corpórea - entenda-se aqui não só o princípio físico do som como onda reverberando e fluindo no tempo e no espaço, mas também todo um corpo atômico, sanguíneo, com ossos, passagens, cavidades, a respiração e seu impacto muscular, tão como impulsos, desejos e sensações, cuja matéria-prima também é molecular e embebida na química da matéria - tão como se relaciona com possíveis aspectos semióticos em práticas nômades que investem energia em estratos comunicativo-discursivos da linguagem. Um balbucio ininteligível, um sussurro indiferenciado, um grunhido, a ofegância, os diversos sons bucais/vocais relacionados à respiração, o atrito da língua, das pregas, dos dentes e a própria articulação da palavra-som em línguas imaginárias como é o caso da glossolalia e outras práticas que se relacionam com ela como o grammelot e o gibberish ${ }^{12}$, por exemplo, podem fazer parte de uma variação contínua para desarrazoar a voz.

Demais, a palavra escrita e falada também faz parte de um conjunto de práticas glossolálicas, como é o caso mesmo de Artaud e vários movimentos que eclodiram no séc. XX como a poesia sonora, como será considerada adiante. A glossolalia engloba, pois, as construções semióticas na produção de subjetividades, operando de maneira singular nos estratos da língua. Ao mesmo tempo age como um delírio de linguagem, entendendo o delírio como um modo de efetuação do desejo entre as estruturas, uma função com princípios a-significantes como veremos com Deleuze e Guattari. O caso Artaud aponta uma retroalimentação das instâncias vocal e escrita, de tal modo que a voz, enquanto ruído do corpo, funciona como território de experimentação enquanto matéria que faz vibrar.

Dissociando-se da palavra, mas ainda num território de experiências do som na voz, Demetrio Stratos $^{13}$ em sua noção de voz-música, faz o movimento nômade de levar para o meio musical, principalmente para a voz cantada e falada, tudo aquilo que é considerado estranho, ruidoso e feio na produção vocal, dando um valor singular ao som e seus parâmetros para a performance vocal. Janete El Haouli, referindo-se a Stratos, fala de uma "vocalidade do desperdício", ou ainda, da "vocalidade como excreção", dando atenção à voz desprezada por uma "moralidade vocal" (2002: 50). Estes aspectos da pesquisa de Stratos fazem parte da performance vocal como potencializadores da produção e percepção de sentidos variados na

\footnotetext{
${ }^{12}$ Ver glossololalium.

${ }^{13}$ Grego, naturalizado italiano, foi cantor, músico e pesquisador da vocalidade em performance. Criou a noção de voz-música. Aspectos de sua obra são apontados em 'antistratosquo'.
} 
experiência cênica e performática, de tal forma que as fronteiras destas sonoridades possíveis suscitam a exploração do limite da voz humana.

Uma peculiaridade de uma noção de glossolalia aqui discutida diz respeito a uma palpabilidade da voz enquanto corpo sonoro, onda que reverbera, que traz uma presença peculiar no ato de enunciação em performance, atribuindo valor intrínseco ao som em si mesmo. De alguma forma, uma voz sugerida em Artaud é perpassada pela busca por uma materialidade da performance, por sua linguagem concreta e sua fisicidade cênica, procurando recuperar este potencial na enunciação sonora, sobretudo no ato de proferir vocalmente. Um dos grandes dilemas em Artaud é justamente o movimento do intelecto e um possível pacto dele com a matéria, um intelecto que almeja ser a própria matéria da experiência. Trata-se de um furor atômico, molecular. Dessa forma, a voz funda também um acontecimento visceral que, excitando sua própria matéria, procura excitar a matéria do outro. Ele propõe uma função pré-linguística à palavra como parte de uma função física da cena:

[...] se voltarmos, por pouco que seja, às fontes respiratórias, plásticas, ativas da linguagem, se relacionarmos as palavras aos movimentos físicos que lhes deram origem, se o aspecto lógico e discursivo da palavra desaparecer sob seu aspecto físico e afetivo, isto é, se as palavras em vez de serem consideradas apenas pelo que dizem gramaticalmente falando forem ouvidas sob seu ângulo sonoro [...] (1999:140-141).

Artaud suplicia por uma linguagem vital, sensível, que pactue com um pensamento de sangue e osso. Uma cartografia sobre uma possível voz glossolálica em sua obra será o ponto de partida para uma discussão sobre a voz em performance na confluência de princípios aqui sugeridos. Que linguagem estranha veio povoar a obra e a voz de Artaud nos últimos anos de sua vida?

Partindo de sua obra, sobretudo do período que compreende seus primeiros anos de asilo (setembro de 1937 a fevereiro de 1943), e, principalmente o período de Rodez (fevereiro de 1943 a maio de 1946), passando pelo seu retorno à Paris até sua morte (março de 1948), esta pesquisa propõe-se a uma investigação sonoro-poética com foco na produção da voz em performance em torno de uma noção de glossolalia, também voltada para aspectos de uma presença corpóreo-material do som vocal configurado por seus parâmetros. O que suscita uma experimentação da voz enquanto devir glossolálico? Como um conjunto de práticas relacionadas a tal vocalidade pode contribuir para o trabalho do ator e do performer? Como, a 
partir de uma noção de linguagem, um nomadismo pode povoar a voz possibilitando tatear um aquém e um além desta mesma linguagem?

As pulsões na obra de Artaud fizeram vibrar um amplo campo conceitual com ressonância em autores que desta fonte beberam como é o caso da filosofia de Deleuze, Guattari e Derrida como mencionado antes. Fazendo vibrar estas zonas de intensidade, o rumor de uma glossolalia se fará ouvir nas possibilidades de uma ressonância poético-conceitual, tendo na vitalidade de uma noção de crueldade a sugestão de um delírio vocal. Qual o limite da criação vocal? Com o que pactuo na investigação de uma voz cruel, uma voz excessiva, uma vocalidade possibilitada por uma noção de glossolalia?

Relacionando a glossolalia a valores e conceitos como o ruído, o excesso, a experimentação constante, a ininteligibilidade, a crueldade, o corpo sem órgãos, ela parece rumorar a hipótese de uma vocalidade entre, mesmo o entre das vocalidades, os entres da própria voz. Ruidosa hipótese: A multiplicidade do corpus da obra de Artaud pode contribuir para uma poética do devir vocal, sobretudo numa noção de glossolalia, possibilitando ao ator e ao performer contemporâneo, uma investigação sobre nomadismos da voz em performance. Desmedida vocal: desalojar, deslocar a voz para além do locus de cada dia, além do métron ${ }^{14}$ vocal de cada um. Num recorrente rumor hipotético, a glossolalia, enquanto conceito múltiplo, agrega muitas camadas das práticas enunciativas, possibilitando a voz dizer-se a si mesma enquanto matéria sonora para 'o' fora de discursos e linguagens, podendo enriquecer a experimentação vocal do ator e do performer. E no seio da hipótese, desmedidamente posta, rumora ainda: $\mathrm{O}$ que pode a voz? Ingrato e saboroso koan $^{15}$ : Qual a diferença entre a voz?

Na conveniência de agenciar conteúdos em torno de uma possível vocalidade, para além do fato de lidar com a legião que sou, também procuro fazer um movimento em direção ao outro,

\footnotetext{
${ }^{14} \mathrm{O}$ conceito de medida é fundamental no contexto da Grécia Clássica. O métron, medida do homem dada pelos deuses, alia-se a valores para uma ética grega como a harmonia, o comedimento, a prudência, o bom senso, o ideal de beleza, a medida poética e a ordem social. Este conceito está diretamente relacionado à hybris, que é uma desmedida, uma transgressão de limites, um ultraje, um excesso que rompe a medida do homem. Na tragédia grega, o herói trágico, colocando-se numa situação de perigo por ultrapassar sua medida, cumpre seu destino trágico por entrar em conflito com a ordem do mundo e dos deuses. Princípios sobre uma ética que permeava a sociedade grega em seu período clássico, podem ser observados em 'Paidéia, a Formação do Homem Grego' de Werner Jaeger (2003).

${ }^{15} \mathrm{O}$ koan é um recurso utilizado no zen budismo. Pode ser uma sentença, uma narrativa, um diálogo, uma anedota, cujo fim deve transcender os recursos intelectivos da razão. Deve provocar o sentido mais direto e objetivo, fazendo-o perder-se. Não é conveniente meditar sobre um koan detendo-se no que as palavras parecem dizer. Soa como um enigma: 'Qual o som do silêncio?' ou 'Qual o som de uma das mãos ao bater palmas?'. Alguns princípios do koan são apontados por Albert Low em seu livro 'A vaca de ferro do zen' (1997).
} 
assim como uma produção vocal também aponta para possíveis alteridades. Pois, no intento de fazer reverberar outros corpos por meio de um rumor conceitual, fomentando subjetividades, possibilitando imagens, ressignificando sentidos e partilhando de uma cartografia singular, não posso me abster do alcance de uma dimensão relacional. A própria noção de pacto alimentada pela poesia das fronteiras como fenômenos de borda ${ }^{16}$, configura as possibilidades de uma alteridade que, passando pelo humano, também se investe no inorgânico, pois escrever me inquieta como uma necessidade de pactuar com o cosmos. Nesta busca de experienciar o outro, de excitar alguma ressonância, aqui intentada numa discussão em torno de uma noção de vocalidade, a cartografia me possibilita a imersão em estratos políticos, lúdicos e poéticos como forma de fazer um devir singular afetar e ser afetado na partilha de uma poética pessoal.

A cartografia transformou-se num método aberto de pesquisa com uma permeabilidade singular aos acontecimentos e mutações do pesquisador, do artista e de qualquer um que queira acompanhar o fluxo e os afetos de sua própria transformação em relação à experiência com o seu tempo. Para Suely Rolnik "a tarefa do cartógrafo é dar língua para os afetos que pedem passagem [...] que esteja mergulhado nas intensidades de seu tempo, atento às linguagens que encontra, devore as que lhe parecerem elementos possíveis para a composição das cartografias que se fazem necessárias" (2007: 23). Rolnik fala do estado de fuga do cartógrafo que, como um antropófago, alimenta-se de matérias de qualquer procedência, embrenhando-se em territórios inauditos, ou seja:

Não tem o menor racismo de freqüência, linguagem ou estilo [...] Obedecendo aos procedimentos e aos princípios básicos do cartografar, o estilo procura realizar a vontade de expandir os afetos, de navegar com o movimento e de devorar os estrangeiros para, através das misturas, compor as cartografias que se fazem necessárias (ibidem: 232).

Diante dessa porosidade metodológica, há o desejo de uma dissertação experiencial perpassada por sangue e osso para usar uma expressão de Artaud. Possibilitar que algo, tratando dos elementos sonoros e também não audíveis da voz, possa marulhar nos ouvidos

\footnotetext{
${ }^{16}$ Os fenômenos de borda têm no anômalo, condição da aliança necessária ao devir, o agenciador da experiência. Deleuze e Guattari apontam fenômenos limiares e fronteiriços como possibilidades de pactos para diversos devires. E o que seria o anômalo? Eis a hipótese dos autores: "[...] uma multiplicidade se define, não pelos elementos que a compõem em extensão, nem pelas características que a compõem em compreensão, mas pelas linhas e dimensões que ela comporta em 'intenção' " (2005: 27). O anômalo povoa uma zona cuja política é a da feitiçaria.
} 
do leitor no desvelo de camadas e mais camadas. Porque escrever é pactuar, pois a dimensão do outro é o horizonte das descobertas partilhadas na alteridade. Experiência. Esta "contém inseparavelmente a dimensão de travessia e perigo" (Bondía, 2002: 25), assim, o pacto, zona intensa de si na troca com o outro, pressupõe uma ex-posição, pois "é incapaz de experiência aquele que se põe, ou se opõe, ou se impõe, ou se propõe, mas não se ex-põe" (idem). Percebo aqui, os riscos poéticos-conceituais, as escolhas desmedidas, os excessos de uma forma, a insensatez de um errar desmedidamente humano.

Assim, na busca por fazer reverberar inquietudes no leitor, o aspecto formal dessa pesquisa é perpassado também por uma escrita que procura ressonância nos conceitos tratados. A opção por um leitmotiv em forma de perguntas recorrentes, insistentes, como um bordão, uma vibração base, que não abandona o horizonte da pesquisa, mas que também aponta para além deste horizonte, se desdobrando em outras perguntas como num recorrente devir das respostas, que é um devir do perguntar. Por vezes, se não sempre, deixo escorrer o coração, pois embebidas em paixão, as palavras têm mais liberdade para enlouquecer. Um coração que renuncia alguns saberes, o coração como em Derrida, o ouriço e a poesia ${ }^{17}$. Assim, algum excesso faz-se passar, com ares de manifesto, ares de grito, palavras que sobram na súplica de um adjetivo, e outro e outro, mas não se contentam nunca, deixando-se entrever além das reticências. Esse excesso enquanto poética, enquanto rumor conceitual, vai ao encontro da glossolalia, de um transbordar-se como vinho sonoro, um vinho curtido em barricas de linguagens estranhas e aromas antigos, de uma voz que se lança na entrega desmedida de dizer-se.

Diante da forma, a dissertação segue uma estrutura redimensionável, por vezes fortuita, como zonas instáveis e cambiantes. Ouso dizer que pode ser lida a partir de qualquer ponto sem comprometer significativamente o processo de leitura. Constitui-se de títulos, lugares de travessias, sobre os quais debruçam-se algumas sombras e penumbras poético-conceituais, vestígios de intervenções linguísticas tão comuns às glossolalias no campo da arte. Na busca por compreendê-los, sobretudo na sua relação com o texto, algo parece desarrazoar, uma curiosidade é suscitada e, muitas vezes, o sentido permanece aberto, provocando, instigando e possibilitando o imaginário do outro. Zona lúdica, aberta a um constante desvelar, os títulos seguem como territórios borrados, suscitando ruídos de vozes. Como recurso formal, optou-se

\footnotetext{
${ }^{17}$ Che cos'è la poesia?, in Inimigo Rumor, Rio de Janeiro: 7 Letras, 2001, p. 113-116.
} 
por não italicizá-los para que não se confundam com uma palavra estrangeira ou com um conceito que requer um grifo para singularizá-lo dentro de um léxico. São portadores de conceitos, poéticas e imaginação. Eles carregam partículas de outras línguas, por vezes são escritos inteiramente em outra língua, enunciam enigmas, lançam jogos fonético-semânticos, agregam criações que desarrazoam o significado, além de invenções e licenças poéticas no contexto da pesquisa.

Em 'qual a diferença entre a voz?' pondera-se uma noção genérica de voz em torno de alguns conceitos da filosofia de Deleuze e Guattari. Em 'cricriptatore' os afetos são voltados para Artaud e sua poética da crueldade, daí vislumbra-se uma vocalidade a partir da obra do Mômo $^{18}$. Tal vislumbre é projetado em 'theatrum vita philargica', que vai discorrer sobre uma materialidade pretendida por Artaud, passando por uma noção de corpo, cuja trajetória vai de uma noção de um atletismo afetivo até a eclosão de um corpo sem órgãos. Daí uma ressonância em Deleuze e Guattari cujas práticas de dessubjetivação, a-significação e desarticulação vão dar um valor intensivo para o trânsito do desejo de tal vocalidade. Em jo)

procura-se definir a glossolalia, situando seus múltiplos contextos. Discute-se questões conceituais a partir de Michel de Certeau e Alessandra Pozzo, ponderando uma noção de glossolalia para a performance. Em 'a rangmbde a rangmbde a rouarghambde' retornamos a Artaud e à discussão sobre como a prática glossolálica se deu em sua obra. Também é abordado o conceito de subjétil de Derrida em torno da criação de Artaud. Já em 'antistratosquo' e '...babelybablelyblablelyblablabely...' a noção de glossolalia é ampliada dentro do espectro da obra de Demetrio Stratos (música) e Andrei Bely (literatura e filosofia da linguagem). O 'glossololalium' é um glossário sobre termos afetos à glossolalia que foi criado no percurso da pesquisa. Sua abertura aponta as possibilidades imensuráveis dos entres numa pesquisa sobre uma voz glossolálica. Em 'qual a diferença entre mim?' preparo o terreno para minha prática, situando o contexto de uma singularidade que procura experimentar a voz em performance. A apropriação de uma noção de pacto com o diabo aliada à noção de limitrofia em Derrida, aponta para as confluências do ato criativo. Em 'epifonia' e 'blefarite' que são recortes cartográficos de processos práticos de uma voz

\footnotetext{
${ }^{18}$ Em 1946 Artaud publica o poema Le retour d'Artaud, le Mômo, apelido dado a si mesmo. Mômo tem uma infinidade de significados. Entre eles, apontado por Derrida em Artaud le Moma (2002), o de zombador, que ataca com ironia e sarcasmo, à maneira de um bufão. Jacques Prevel em En compagnie d'Antonin Artaud (1994), traz uma nota com outras etimologias para a palavra Mômo: um idiota sagrado, também môme (criança, garoto) + momie (múmia), ainda, uma criança em marselhês.
} 
glossolálica em performance, cujos arquivos de áudio são analisados sob uma noção de parâmetros do som, perscruta-se a voz enquanto suporte sensorial de uma experiência estética, aludindo à sua materialidade como potência na produção e percepção de sentidos.

Epifonia e blefarite fazem parte de um conjunto de práticas glossolálicas, incluindo recursos da palavra e da língua, que foram efetuadas no período da pesquisa e mesmo antes, em improvisações diárias, como um uso lúdico da linguagem e da voz. As diferenças entre os dois recortes apontam para uma multiplicidade de usos dos parâmetros do som ${ }^{19}$ na conveniência de uma prática glossolálica para a performance. Demais, sugere-se um aquém e um além dos recortes como potências que fazem agenciar a voz. São apontamentos que não esgotam as possibilidades de tal vocalidade, inclusive porque o fim de tal prática não intentou um material estético acabado, mas buscou discutir questões pertinentes à voz em performance sugerindo aberturas para sua investigação. Diante da fugacidade da voz, da singularidade do desejo em sua prática, sob os princípios de uma vocalidade que não busca se sedimentar, mas antes aponta para uma noção de inacabado, a cartografia possibilitou-me a singularidade dos registros aqui partilhados em um significativo percurso de improvisos e escutas de sonoridades que alimentaram a pesquisa.

Três epígrafes foram experimentadas como textos fictícios, num híbrido de escrita teatral com entrevista, servindo como uma instância porosa cujas ressonâncias e reverberações fazem referências ao conjunto do trabalho, mas que também inferem singularidades das sessões que a elas seguem. Uma delas apresenta Artaud, que será explorado em várias sessões e as outras duas antecedem as criações sonoras 'epifonia' e 'blefarite', ainda mantendo emanações poéticas do Mômo, mas reconfigurando e sugerindo potências a serem exploradas na criação performática.

Diante da assertiva "Uma saída? Um pacto com o diabo? A esquizoanálise ou a pragmática não tem outro sentido: faça rizoma, mas você não sabe com o que você pode fazer rizoma, que haste subterrânea irá fazer efetivamente rizoma, ou fazer devir, fazer população no teu deserto. Experimente". (Deleuze; Guattari, 2005: 35), procurei fazer alianças e revolver algumas profundidades em mim, experimentando as possibilidades de uma crueldade na voz, procurando tatear sua possível ausência de órgãos. Assim, gostaria agora de sugerir um pacto

\footnotetext{
${ }^{19}$ Desdobrada nas análises de 'epifonia' e 'blefarite', a noção de parâmetros do som no contexto dessa pesquisa pactua com a perspectiva de César Lignelli (2014).
} 
com o leitor! Esta pesquisa é sobre som, sobre o som da voz, ainda que seja das potências virtuais de uma voz e, dessa forma, é sobre uma necessária escuta, que faz parte de um conjunto de práticas para se aproximar de tal vocalidade. Embora não seja o foco direto da pesquisa, a escuta faz parte da percepção e produção de sentidos a partir da dimensão acústica da performance. A entrega à uma escuta requisitada por uma glossolalia traz uma curiosa experiência de estranhamento, sobretudo se a escuta for do próprio som da sua voz procurando experimentar territórios inexplorados: um lugar escuso da voz, amoral, sombrio, ridículo, dissonante, ruidoso... Escutar, dessa forma, é ser poroso às vicissitudes de qualquer voz por mais bruta que ela pareça ser, por mais ininteligível, por mais inaudível que seja. Diante dessas considerações é que proponho um pacto com o leitor: antes de ler-escutar o corpo desta pesquisa, sugiro a escuta de vozes que lhe pareçam estranhas: a voz de Artaud, a voz de Demetrio Stratos, glossolalias em contextos religiosos e psiquiátricos, fórmulas cabalísticas, liturgias que você desconhece, dialetos estranhos, a voz do diabo, seja lá o que isto signifique pra você... Há uma discografia consultada junto às referências, e a maior parte é acessível na internet, demais o espectro de vozes desarrazoadas é amplo e uma simples busca lhe propiciará achados. Se você puder avançar um pouco mais e dedicar-se a se escutar tateando o estranho na sua própria voz, então o pacto estará feito e você saberá como Riobaldo, personagem de Grande sertão: veredas de Guimarães Rosa (2006), soube nas veredas-mortas. Pode parecer um detalhe, mas se você se escutar de olhos fechados, sozinho, num ambiente silencioso, avançando um pouco a madrugada, sua experiência terá outra singularidade ${ }^{20}$.

Por fim, ou melhor, reconfigurando novos inícios, uma reflexão se detém sobre os limites e as fronteiras do que pode a voz em performance. O retorno de 'abracadabra' aponta perspectivas e desdobramentos da pesquisa: um ressignificar do que se pôde ouvir entre abracadabras. Como conceito aberto e poroso, a glossolalia aponta para práticas nômades de uma vocalidade em contato com os subterrâneos de uma sonoridade sempre em vias de fazer alianças com o insólito. O devir vocal segue, enquanto bicho selvagem à espreita de uma predação, enquanto zona poética e investimento de desejo, segue como um louco transbordando lucidez numa linguagem estranha, nem sempre tão estranha, estúpida às vezes, excessiva, suja, amoral,

\footnotetext{
${ }^{20}$ Fico imaginando a perturbadora 'hora do lobo' mencionada por Johan, personagem do filme 'A hora do lobo' (1968) de Ingmar Bergman. Para os antigos era o período da madrugada, entre a meia-noite e a aurora, em que a maioria das pessoas morriam e nasciam.
} 
amorosa no sentido de uma atração, mítica, humana, demasiado inumana. Uma voz assim: etecétera. 


\section{qual a diferença entre a voz?}

A voz: zona de intensidades, vibração, um platô, limites e limiares, ressonância do desejo, nem sujeito, nem objeto, matéria pluridimensional em devir, fenômeno, experiência de cada dia, dia após dia. O que ela abre? O que ela fecha? Emana o desejo, reverberando em outros corpos, cartografando outras configurações, possibilitando nomadismos no terreno inquieto da performance: na complexidade de dizer-se a si mesma, que alianças pode a voz? Intento fazer ressoar no leitor um balbucio poético, fazer vibrar um rumor conceitual, criar atração, zonas e pontes. Pois que se escute aqui uma voz, outras vozes, que se vislumbre um mínimo desvario vocal capaz de levar o desejo para outros tempos-espaços, outras investigações, lugares em que o risco de não saber também suscita a experiência: O quê? Como?...

Delírios sobre um koan: "qual a diferença entre a voz?" surgiu de uma brincadeira filosófica baseada na prática do koan no zen budismo. Pois, diante da pergunta, na impossibilidade de colocar a voz em relação a isto ou aquilo, me volto pra ela mesma como um universo infindo de discussões que não procuram, em absoluto, uma identidade ou resposta, mas que faz passar intensidades como trânsito do desejo. Desejar as fissuras, as bordas, os limiares, o entre como regiões que fazem povoar agenciamentos em que a diferença se faz proliferar. Eis que um universo conceitual fez delirar o koan: Deleuze e Guattari reverberando.

A filosofia da diferença em sua crítica à uma tradição filosófica fez irromper um pensamento transversal e múltiplo que busca fazer mundo participando do mundo, ou seja, a criação de conceitos é uma ação ante a vida, para a vida, em seus muitos contextos de conhecimento. A diferença implica uma coletividade política que marulha a existência na experimentação por espaços e territórios e, por isso, sua crítica a princípios históricos, identitários e representativos, pois a alternativa da singularidade importa instabilidades na experiência diante do reconhecimento do outro. Há uma legião de autores e pensadores que partilham de um pensamento complexo, logo diferencial, como é o caso de Deleuze, Guattari, Derrida, Foucault, Nietzsche, presentes nessa pesquisa, no entanto não há aqui um movimento de ampliar uma noção diferencial em relação às particularidades desses autores, antes disso, a diferença emana como algo que vibra, reverbera e ressona dentro de contextos necessariamente porosos, fazendo pontes e sugerindo experimentações. Demais, diferença não se explica, experimenta-se. Dessa forma, todas as contradições e idiossincrasias pertinentes a 
um tal pensamento permeiam as sugestões de uma vocalidade e a forma como são tratados os temas afetos a esta pesquisa. É o desejo produzindo mundo.

Se, para Deleuze, desejar é de certo modo delirar, pois se delira sobre o mundo, o que torna o delírio cósmico, uma noção de voz aqui pretendida vai ao encontro desta filosofia do desejo, que, entre outras coisas, intenta experimentar agenciamentos. Agenciar implica diferença como instabilidade e movimento do mundo. Não se trata da busca de uma identidade vocal, pois a presença necessária de territórios evoca movimentos que corroboram com o nomadismo na filosofia deleuziana. Uma poética da natureza que tem como princípio a diferença. Dessa forma, não pretendo sair à procura de mais uma definição da voz, mas vou sugerir aspectos que podem fazer parte de uma noção de voz para a performance. O que pode a voz nesse contexto?

Assim como suscita o koan, a resposta a esta pergunta é um conjunto de agenciamentos, emaranhar-se na investigação. Ela não estabiliza a discussão, antes, coloca-a no olho do furacão. Isso me leva a vislumbrar potencialidades virtuais da voz e atualizações singulares dessa $v z^{21}$. O que também implica dizer que a voz tem realidades distintas no seu devir, que não significa somente uma realidade sonora, mas que comporta outros potenciais embrionários, incubados, em gestação. Esta realidade não necessariamente antecede à atualização da voz, pois ela já tem existência plena que pode ou não ganhar uma outra realidade enquanto som. Embora não seja o foco aqui, tratar destes aspectos não sonoros, e não tão palpáveis e explícitos da voz em performance, faz-se conveniente tratá-los como intrínsecos a um devir vocal em práticas glossolálicas, apontando para um conjunto de valores em processos de a-significação, desarticulação e dessubjetivação ${ }^{22}$. Demais, há um impacto sensorial desses agenciamentos moleculares, pois tanto em sua produção, percepção e escuta, uma matéria é movimentada enquanto corpo, pois a voz é perpassada e se faz perpassar por uma singularidade.

Quais territórios? Nomadismo em relação a quê? Quais diferenças? Entre o quê? Quais os pressupostos deste pretenso devir vocal? Quais limites? A glossolalia enquanto impulso

\footnotetext{
${ }^{21}$ Deleuze em 'Diferença e Repetição' (2009) suscita a discussão sobre o virtual e o possível, que terá um desdobramento na obra 'O que é o virtual' (2011) de Pierre Lèvy. A filosofia deleuziana fez repercutir a grande potência e realidade do virtual e sua atualização.

${ }^{22} \mathrm{O}$ organismo, a significância e a subjetivação são, de acordo com Deleuze e Guattari, os estratos básicos sobre os quais se investem um conjunto de práticas que engendram um corpo sem órgãos. Os princípios destas práticas são tratados em 'theatrum vita philargica' com foco em Artaud.
} 
conceitual para uma prática da voz em performance aqui tratada, lida de uma maneira peculiar com determinada noção de discurso, língua, signo, significação, comunicação, representação, inteligibilidade e compreensão na enunciação vocal. Na busca para exceder alguns limites, pessoais, institucionais, morais, tal possibilidade vocal abre-se para potenciais ruídos e sonoridades que fazem estranhar algumas fronteiras: entre o animal/selvagem e o homem e sua linguagem, entre a linguagem e o silêncio, o grito e a música, entre o significado e o sentido $^{23}$.

Investindo no contrassenso, no insensato muitas vezes, experimentando dentro de contextos que fazem extrapolar as palavras, que imergem no som em si mesmo e seus parâmetros, em processos de improvisação, nas passagens de um limite a outro, na maquinação dentro dos territórios, no jogo lúdico de fazer a voz delirar-desejar, enfim, diante do enorme potencial de desarrazoar e fazer estranhar, é que insinuam-se as possibilidades de uma voz como resto e excesso. Dar atenção e deixar com que passem, numa escuta receptiva e numa produção vocal porosa, as camadas infindas de ruídos e micro-movimentos, as ininteligibilidades dos discursos, a modulação dos parâmetros do som numa experimentação constante, as sonoridades como matilhas de animais, abrindo-se a formas imperceptíveis. Um entre possível da voz: dimensão das experiências, de entregas permeáveis, aberturas da alteridade, das curiosidades lúdicas da criança.

Ainda a voz: seu devir em performance, enquanto produção do desejo, tem um grande potencial nômade em relação à linguagem, ao signo e aos processos de significação enquanto representação. Possibilita o som com valor em si mesmo, independente de aspectos significantes externos à sua materialidade sonora. Tem esta materialidade singularizada por um corpo, pois tem uma endo-existência como potência virtual do som em processos físicos e subjetivos para sua produção, e uma exo-existência ${ }^{24}$ enquanto manifestação acústica e ressonância no outro em sua alteridade. O desejo, alguém que vocaliza, um devir que é processual e o outro.

\footnotetext{
${ }^{23} \mathrm{O}$ significado enquanto zona mais estável, objetiva, mais próxima da literalidade, da norma e da precisão e coerência e o sentido relacionado aos múltiplos contextos, por isso, mais amplo, instável e sujeito às perturbações e inconstâncias das leituras de mundo, inesgotável e complexo.

${ }^{24}$ Deleuze em 'O que é Filosofia?' (2004) fala da endo-consistência e exo-consistência do conceito. Aquela se refere à consistência interna do conceito e sua dimensão absoluta como zona ou limite, enquanto esta denota a possível relação com outros conceitos numa noção de ponte. Na noção de voz como devir, endo se relaciona ao processo que antecede à sonorização da voz e exo à sua reverberação enquanto som tendo na alteridade sua possibilidade de ressonância no outro.
} 
Quem sou eu nesse processo? Temos aqui uma singularidade, colocar-se na relação com o outro. Dessa forma, a voz não é somente onda sonora, propagação ou reverberação acústica, ela é gestação, ela antecede o tempo da matéria, também é matéria ou, ao menos, agencia outras matérias. Quando digo expressões como 'A voz presa na garganta' ou 'O que eu não disse vive em mim criando um vazio imensurável' ou 'Vou pesar o que dizer', entre tantas outras possibilidades, existe uma presença factível daquilo que pode ser ou não sonorizado e, ao mesmo tempo, faz-se reverberar em sinapses, emoções e sentimentos, em sensações, em espasmos musculares: o nó na garganta, um buraco existencial, uma densidade a ser ponderada... $\mathrm{Na}$ escolha por calar-se, aquilo que poderia ser audível ganha uma outra existência que pode ou não ser atualizada no som. Neste caso, o 'Quem sou eu?' implica cartografias que lidam com as potências de uma voz gestada e de seu êxodo enquanto forma sonora, um corpo, uma singularidade.

E uma voz outra? Uma voz entre? Uma voz glossolálica. Que corpo a habita ou é habitado por ela? Que corpo a possibilita? Trata-se de escavação pessoal, mergulho em si, pois ainda que coletiva, essa voz tem o espectro dos micro-devires que posso fazer passar na conveniência do que procuro agenciar: um conjunto de práticas para uma vocalidade em glossolalia.

As vocalidades da cena perpassam o trabalho do ator e do performer exigindo-lhe um investimento peculiar de energia em sua investigação. Chegar ao outro pela voz, sendo voz, de formas multiplicadas na pesquisa de sua sonoridade, exige a abertura para criar e um senso de subversão. Subverter: antes mesmo de uma ideia de transgressão, imagino a força etimológica desta palavra, sub (embaixo) + verter (de vertere - derramar, transbordar) ${ }^{25}$, verter sob o discurso outras possibilidades de sentidos, verter outros sons num subtexto, verter sub-repticiamente. E transbordar não é exceder? Ultrapassar a medida? O que verto? O que é vertido em mim? O que me subverte?

A fenda, o rasgo, a fissura, o talho, a porosidade, a permeabilidade, o furo, o poro, a boca, o coração, o outro: abertura. No entrar e sair, no reter e perder ou deixar passar, na travessia deixando-se atravessar, eis que veio transitar Artaud, no veio da pesquisa. Ocaso Artaud: a luz vermelha banhando as palavras de um vinho intenso, crepitante, e um súbito entardecer de nuvens ruidosas aproximam-se com sangue e furor, dançar com demônios na reverberação do crepúsculo...

\footnotetext{
${ }^{25}$ Ver Silveira Bueno (1968).
} 
Personagens: Artaud, Artaud e Coro.

Um dos Artauds é realmente Artaud, nascido em Marselha, França em 1896. A princípio, o próprio Artaud deveria fazer seu próprio papel. Um homem muito magro, com os olhos fundos, lábios finos, cabelo desgrenhado, as mãos intensas, fortes. Procura sempre ajeitar o cabelo. Seu olho tem uma luz estranha, mistura de loucura e lucidez. O outro é outro Artaud. O coro é uma reverberação dos Artauds, milagre da multiplicação. Encarna os demônios de Artaud, suas múltiplas vozes. Mutante. Antes do espetáculo começar, o coro está entre o público, espalhado pela sala de apresentação ou no meio da rua, dependendo do espaço escolhido para encenação. Ele compõe o burburinho antes do início da peça, emite sons indiferenciados, tagarela, balbucia. $O$ coro, antes disperso, se aglutina e segue para o palco como numa procissão, carregando um dos Artauds, que está em agonia, como numa morte. $O$ coro também agoniza como um coletivo sucumbindo a uma peste. $O$ ápice da agonia acontece no palco. $O$ coro aplaude com furor a agonia de Artaud, começa a vaiar por um tempo e depois se cala. Resta Artaud, ofegante, murmurando, ensopado de suor. O outro Artaud entra em cena e anuncia.

Artaud - Eis Antonin Artaud. Desse homem eu "guardo uma lembrança indelével, atroz, dolorosa, quase sublime por instantes, revoltante também e quase intolerável"26. Um homem com uma fome austera, um hálito opiáceo, esforçando-se em frenesi para que sua gagueira de nascença seja escutada. Um gago, um corpo gago, uma língua gaga...(sua voz vai sumindo, calandose como num sonho, os gestos permanecem, os movimentos dos lábios também, enquanto o outro Artaud começa a cantar uma canção francesa muito antiga, tão antiga que provavelmente ninguém vai se lembrar dela, tão antiga que o francês arcaico parece incompreensível, quase paleolítico).

Artaud - (Acaba a canção. Ele procura se explicar de maneira ponderada, calma, meditada) "mêsêtressontleculédureculant, ilsbrûlent, ilsbramalent, ilsbraumonblent, ilsbromombruptrulent, ilstrulentrombentrule, tremptrudrudurditritrile, ilskatachemusanbritent" 27

Artaud - Trule tritrile?

Artaud - Quatritrile du bromobraumon... Diriam brutal ou violento, quem sabe neurótico... Pensariam num quartinho cheio de láudano e ópio, um corpo cheio de escritos e cadernos, uma psiquiatria cheia de velhos,...

Artaud - E por aí seguiu, ganhando estas rugas bizarras, uns dentes a menos, este aspecto febril e insolente, e os olhos cheios de... cheios de...?

Artaud - Cheios de quê?

Artaud - Cheios. Tão cheios que deles se derramam estes... estes....

Artaud- O que se derrama dos meus olhos?

Artaud - Eu não consigo dizer as palavras certas.

\footnotetext{
${ }^{26}$ Comentário de André Gide a respeito da conferência de Artaud no Vieux-Colombier (Mèredieu, 2011: 896).

${ }^{27}$ Epígrafe de Artaud (ibidem: 905).
} 
Artaud - Então diga as erradas, não as diga, simplesmente, ou grite. (Eles se olham fixamente fazendo os olhos brilharem o máximo possível, fazendo-os transbordar uma imprecisão lunática. Um Artaud dá um grito lancinante, seguido de um acorde estrondoso e dissonante do coro. Silêncio. Um Artaud começa a murmurar, é seguido pelo outro que é seguido pelo coro. Reverberação. Algaravia. Enxame de vozes como uma revoada de pássaros ou um grande cardume, as vozes zigue-zagueiam pelo espaço. Os cantos em linguas estranhas devem parecer espectros vagueando pelo espaço. Numa coreografia, os Artauds movimentam-se com as vozes, avançam sobre o coro, recuam, correm, dançam. Lirismo).

Artaud - Quê sá çinifi? Quê-sá-çi-ni-fi? (Um Artaud e o coro marcam o ritmo da pergunta, escandindo a frase e repetindo-a. Parte do coro diz 'Quêsá-çi-ni-fi?', outra 'Sá-ci-quê-fi-ni?", outra 'Çi-sá-fi-quê-ni?', formando linhas melódicas que sempre acabam num acorde dissonante. Artaud procura falar aos berros em meio à massa sonora da pergunta que segue ritmada).

Artaud (gritando) - Trata-se de "A verdadeira história de Jesus Cristo" para uma transmissão radiofônica, um teatro da cura cruel, difícil dizê-lo, melhor fazê-lo... Estou tentando dizer, mas o que digo se esforça muito pra nascer... as coisas assim, nascem no excesso, em excesso, mas não querem nascer, procurando uma forma autêntica...

Coro: Qui?

Artaud: ....autêntica, uma forma autêntica...

Coro: Qui full?

Artaud: Não, não enlouqueci, houve um equívoco do Dr. Ferdière. Ele era o Rei e eu era o Bufão, então eu podia traquinar, tentava e tentava dizer coisas e a linguagem ia se desfazendo em minha boca, diluindo-se no meu sangue, cometia delírios, delírios de linguagem...

Coro: Comu asã?

Artaud: ...uma legião veio povoar minha escrita, minha boca, minha voz.

Coro: Que melle?

Artaud: Antonin Artaud.

Coro: Que que melle?

Artaud: An-to-nin-Ar-taud!!! (O coro cessa de fazer a pergunta ritmada).

Artaud - Não entendi direito.

Artaud - Antonin Artaud.

Artaud - Então apresente-se.

Artaud - Sou Antonin Artaud. Bem, quando eu digo algumas coisas, elas sofreram um processo.

Artaud - De que índole é esse processo? 
Artaud - É como uma despasteurização, voltando à forma bruta, mas não se trata de uma volta simplesmente, pois o bruto que se pasteuriza, ao retornar pela despasteurização, não é mais o mesmo bruto, há uma outra sofisticação... Se eu pego uma palavra e raspo suas falanges, costuro seus pedaços quebrados, furo com certa violência, corto como cortaria um bom bocado de carne virgem, sopro as raspas, digo e desdigo a tal palavra, soprada, esganiçada, ritmada até tornar-se mágica...

Artaud - O senhor acredita em sortilégios?

Artaud - (Silêncio longo) ..., torno-a porosa às liberdades do som, uma pequena blasfêmia do verbo. Resta então a experiência e a cirurgia que me fiz sofrer sobre as línguas, ao fogo de mim... Vês a Lua?

Artaud - Fazendo-a espreitar algum desígnio selvagem? ( $O$ outro aponta o dedo indicador para o alto do céu, a lua brilha e se derrama sobre o palco. Atraídos, os Artauds latem. O coro começa a murmurar pequenos uivos).

Artaud - Animais!

Banhados pela luz da Lua, os Artauds e o coro começam a uivar cada vez mais loucamente para a Lua, os uivos crescem, eles comem a luz do luar com o apetite da vida, lambendo-a com gritos indomáveis. Então, a luz do luar se derrama sobre o público, as pessoas estão banhadas de prata, os Artauds e o coro uivam para o público e, num êxodo de si, precipitam todas as vozes perdidas que fogem em debandada. A luz se apaga. Os uivos permanecem por um tempo. Silêncio.

\section{cricriptatore}

Recordo-me de uma das experiências que marcaram de forma indelével minha percepção sobre a vocalidade em performace: minha primeira audição de 'Para acabar com o julgamento de deus' de Artaud (1947) ${ }^{28}$. Esta audição me afetou de forma inquietante, pois sua estranheza me impossibilitou digerir seus conteúdos num primeiro momento, lançando-me numa sensação curiosa diante do desconhecido. Há época eu não conhecia a língua francesa, o que foi fundamental para a impressão que tive da obra, pois fui tomado pelo aspecto sensorial daquela vocalidade acusmática ${ }^{29}$. Ouvi-o numa língua desconhecida e isto possibilitou-me universos imagéticos muito peculiares a partir das sonoridades propostas.

\footnotetext{
${ }^{28}$ Optou-se, no uso desse texto, pela tradução em português do título original 'Pour en finir avec le Jugement de Dieu', in 'Antonin Artaud - Oeuvres' (2005), embora também tenha sido consultada e citada a versão portuguesa 'Para acabar de vez com o juízo de Deus' (1975).

${ }^{29}$ Para Silveira Bueno (1968) acúsmata, do grego akousma + terminação ata, corresponde aquilo que se aprende pelo ouvido. A palavra refere-se aos discípulos de Pitágoras, cuja técnica pedagógica consistia em fazer com que
} 
Impressões de uma voz inacabada, inquieta, carregada de uma violência peculiar em relação a temas como a sexualidade, tradições do cristianismo, a guerra e os órgãos. Uma noção da crueldade à luz da voz de Artaud. Uma voz capaz de investir em fronteiras do ato criativo do ator e do performer, uma voz nervosa, de um apelo intenso. O que blasfemava esta voz numa heresia aos desígnios de deus? Ao som dos Tarahumaras, a insurgência de uma liturgia antiga, retomada de sua viagem ao México, o rito da noite negra e da morte eterna do sol: Tutuguri ${ }^{30}$. Uma rememoração do rito do peiote, "planta-princípio que nos faz viajar pela realidade [...] que possui a estranha virtude alquímica de transmutar esta realidade" (Artaud, 1992: 73, tradução nossa $)^{31}$.

Um dos raros registros de sua voz pouco antes de sua morte, esta experiência configurou-se num território fértil para reflexões sobre a voz em performance. 'Para acabar com o julgamento de deus' foi sua última obra, engendrada numa dramaturgia fragmentada, povoada de ruídos, uma zona de intensidades para atravessar e ser atravessada por um corpo performático atômico, numa rebeldia à anatomia e sua predileção pelos órgãos. Mas antes mesmo de um afeto político-histórico, ligado a temas e limites da arte performativa num contexto francês, fui tocado e ressoado pelo delírio do som na voz.

Como falar de Artaud sem distanciá-lo demais como se fosse um objeto estético, literário, como pilhas de escritos? Como fazer de Artaud mais que citação ou referência? Como, sobretudo, não aproximá-lo demais a ponto de agonizar e se martirizar como um outro Artaud na rebeldia transtornada de sua via crucis? Ele está aqui. Porque as vozes podem atravessar os tempos, espreitando os ouvidos, insinuado-se como uma matéria resignada a ser revolvida sempre. Compreendo, experiencio ou vivo em algum nível uma noção de crueldade que não pode ser apartada da vida ou mesmo a ideia de um corpo sem órgãos? Isto tornaria minha escrita mais franca, mais vibrante, mais sonante? Minhas vozes chegam por meio do meu texto? Posso separar estas dimensões: a escrita, a vida? O que aqui escrevo é afetado por estas questões, na confluência de desejos e afetos.

seus alunos o escutassem atrás de uma cortina, desvinculando sua imagem do som de sua voz. Para Ángel Rodriguez "Tudo isso nos leva a incluir também no conceito atual de acusmatização essa nova vertente de independência física entre o som e o ente que o produziu originalmente. Pierre Schaeffer e Michel Chion utilizaram abundantemente o conceito com esse novo sentido para pesquisar os mecanismos expressivos do universo sonoro" (2006: 40).

${ }^{30}$ Poema de 'Para acabar com o julgamento de deus'.

31 "una planta-principio que hace viajar por la realidad. [...] que posee la extraña virtud alquímica de transmutar la realidad" 
Há aqui um investimento na ficção, como a multiplicação de um espaço-tempo real, o que me aproxima da vida e do ato de criar. Buscarei uma proximidade e uma devida distância de Artaud, que na verdade é uma aproximação de mim, do que busco, do que aumenta minha temperatura, me dá apetite e, ao mesmo tempo, me alimenta. Isto me faz rememorar Brian Swimme (1995) ${ }^{32}$ e sua história cósmica da criação. Por que as ressonâncias? Por que Artaud aqui? Não seria pelo mesmo motivo pelo qual as pedras caem? No seu livro 'O universo é um dragão verde' Swimme traz uma definição inusitada para o mundo tradicional da ciência: o que os físicos chamam de gravidade, ele chama de amor.

A licença poética não é sem razão. A gravidade é uma força de atração e, ao mesmo tempo, é aquilo que entre dois corpos, une-os e os separa. Há um princípio agregador na gravidade assim como um princípio organizador. Este princípio não pode ser explicado em absoluto, ele guarda os segredos de como as coisas acontecem. Não se pode dizer o que é este 'entre' um corpo e outro, um pensamento e outro. Ele chama esta força de amor, que participa do nível atômico, molecular, galáctico e de toda a subjetividade humana. Uma atividade primária que todas as galáxias exercem umas sobre as outras. Assim como a terra atrai a lua e os planetas giram em torno do sol por meio de níveis distintos de atração, uma pessoa se interessa por Artaud, por filosofia, por teatro, por voz. Ele não fala de um sentimento ou sensação, mas de uma força e uma potência que há 'entre', pois amar, neste sentido, é uma força agregadora e organizadora que pressupõe aproximação e distância na lei da atração universal. Por mais que se aperte num abraço, há sempre um espaço entre os abraços e por mais que a terra atraia a lua, há uma distância que as separa e que, ao mesmo tempo, une-as.

Pela lei da atração universal, subjetividades e corpos são unidos por amor, gravidade de campos psíquicos, físicos, enfim. Percebe-se que a noção de amor dele transcende a ideia trovadoresca do casal amante, ou dos romances que teceram o imaginário ao longo da história. Swimme não está falando de amor humano, mas da atração primária de cada parte do universo por cada uma das demais partes. Há uma vibração que condensa partes do cosmos em alguns coágulos, em espaços mais dispersos, e assim de acordo com a conveniência contextual destas atrações. Assim, um espaço vibratório formou-se em mim e foi aberto pela força da pulsão de Artaud, ante uma alteridade necessariamente compartilhada.

\footnotetext{
${ }^{32}$ Professor de cosmologia evolutiva no California Institute of Integral Studies em São Francisco, EUA. Autor de diversos livros sobre cosmogênese.
} 
Falar de voz, de Artaud, de glossolalia e possibilitar uma pesquisa sobre aspectos de vocalidades em performance, pode ser visto como um movimento do desejo no sentido de buscar conexões por atração. Artaud-Deleuze-Voz-Glossolalia-Derrida-Eu-Você-CsOSubjétil... uma infinda intensidade vibratória que se desdobra em múltiplos agenciamentos, em devir-conceitual, devir-poético, devir-animal, derives, devires, devires. Aqui buscarei a atração entre os conceitos, de modo a exercitar, ou melhor, experienciar, o que Deleuze chamou de "zonas, limites ou derives", como a "inseparabilidade, que definem a consistência interior do conceito" (1997: 32). Experienciar a endo-consistência e a exo-existência dos conceitos. E se "Os conceitos são centros de vibrações, cada um em si mesmo e uns em relação aos outros" (ibidem: 35) e "É por isso que tudo ressoa, em lugar de se seguir ou de se corresponder" (idem), é que farei o possível para que eles se amem, ressonem e reverberem uns nos outros, que criem as "zonas de indiscernibilidade", os deslimites das fronteiras, os entres. E se conceituar e pesquisar é um exercício de criação, que este texto tenha a amorosidade de um ato verdadeiramente criativo.

Falar do outro é também falar de si. Quase sempre é. Senão sempre. De fato, isto é um clichê, no entanto, para além dele, transcendendo uma ideia de 'eu', um devir singular faz agenciar conteúdos. Este outro, eu rumino dia após dia, ele já é outro hoje, será outro amanhã, porque já sou outro sempre. Do que li, do que vi e ouvi, o que pude reter, o que pude digerir, quanto pude, com a devida distância e a necessária proximidade, experienciar de Artaud? Na micropolítica dos afetos, o que me tornei e hei de me tornar dessa experiência enquanto acontecimento? Larossa (2014), citando Heidegger (1987), vai falar da abertura e receptividade, necessários à transformação no ato de experienciar:

[...] fazer uma experiência com algo significa que algo nos acontece, nos alcança; que se apodera de nós, que nos tomba e nos transforma. Quando falamos em "fazer" uma experiência, isso não significa precisamente que nós a façamos acontecer, "fazer" significa aqui: sofrer, padecer, tomar o que nos alcança receptivamente, aceitar, à medida que nos submetemos a algo. Fazer uma experiência quer dizer, portanto, deixar-nos abordar em nós próprios pelo que nos interpela, entrando e submetendo-nos a isso. Podemos ser assim transformados por tais experiências, de um dia para o outro ou no transcurso do tempo (2014: 27).

E assim, no transcurso da vida, de alquimias a alquimias: permeável a Artaud, submetendome a uma pulsão, permitindo-me tatear uma vocalidade sugerida. Lembro-me de quando ia pra cena numa necessidade extrema de acontecer intenso. Sentia-me irmanado com o espaço- 
tempo da performance, pois havia uma violência, no sentido de um ímpeto vital, que possibilitava a vida acontecer intensa e multiplicada. Esta intuição de uma pulsão peculiar no cerne da criação, de um corpo entregue a um espaço mágico, de uma necessidade vital e perigosa no acontecimento artístico, fez-se compreender no ato de expor-me à experiência, ao princípio do que ele chamou de crueldade. Esta é uma militância político-espiritual da afirmação $^{33}$. Nas cartas sobre a crueldade, ele deixava claro que este princípio e a vida eram termos intercambiáveis, a carne da existência perpassada pelo ato de afirmar a própria vida. $\mathrm{O}$ Teatro da Crueldade instaura uma outra possibilidade de se colocar em risco, pois sua compreensão se alinha ao ato de viver, e viver é muito perigoso, como disse Rosa (2006). Questão de vida ou morte. Sobretudo de vida: "Parece-me que a criação e a própria vida só se definem por uma espécie de rigor, portanto de crueldade básica que leva as coisas ao seu fim inelutável, seja a que preço for" (Artaud, 1999: 120).

A clareza dessa afirmação cruel ante a criação é levada ao limite até o fim de sua vida. É como se ele morresse para que a vitalidade não sucumbisse à perda da lucidez. Para Susan Sontag "Artaud não estava, é claro, simplesmente reproduzindo sua agonia interior. Ele estava, mais precisamente, dando uma versão sistematizada e positiva dela" (1986: 35). Dessa forma, Artaud era sobretudo um homem lúcido, ainda que sua lucidez agregasse a loucura como forma efetiva e, neste sentido, soa como o provérbio de William Blake "Se o homem persistisse em sua loucura, tornar-se-ia sábio" (1993: 91). A crueldade exige um investimento do desejo rigorosamente alinhado à existência, pois ela

[...] é antes de mais nada lúcida, é uma espécie de direção rígida, submissão à necessidade. Não há crueldade sem consciência, sem uma espécie de consciência aplicada. É a consciência que dá ao exercício de todo ato da vida sua cor de sangue, sua nuance cruel, pois está claro que a vida é sempre a morte de alguém (Artaud, 1999: 118).

Um devir criativo em Artaud pressupõe a constante afirmação de existir, e existir demanda um pensamento integrado à vida. E que diabos seria um pensamento dissociado dela? Um pensamento carnal, nervoso, sanguíneo, ósseo, cruel enfim. Pensar e mergulhar sua constituição na matéria, como afeto químico, inevitável e agudo, ampliando a pessoa, sua

\footnotetext{
${ }^{33}$ Em seu livro intitulado 'Nietzsche' (2009), Deleuze comenta a afirmação como um princípio fundador da filosofia do alemão. A afirmação é ativa, múltipla e pluralista, sendo a essência ou a própria vontade de potência. Ela afirma a vida e toda criação a ela pertinente, pois nasce da plenitude e da abundância. A vontade, enquanto afirmação, busca por belas possibilidades de vida.
} 
transformação, ele, Artaud, refeito na constância de estar vivo. A afirmação de uma atividade do pensamento é recorrentemente referida por ele, um traço que se relaciona à busca de lucidez, movimentando o corpo em espasmos de uma mente inquieta. Ao mesmo tempo, pensar parece deslocá-lo da existência, parece fragmentá-lo, daí a angústia de perder-se, mas também uma necessidade de se reconfigurar. Este ato é tão fundador que está ligado indissoluvelmente ao instinto mais primário, à fome, aos humores do corpo, a uma corporeidade posta. Viver, neste caso, tem relação com a agudeza do pensar e seu lugar na matéria do mundo:

É tão duro deixar de existir, deixar de estar dentro de alguma coisa. A verdadeira dor é sentir em si o seu pensamento deslocar-se. Mas o pensamento como um ponto não é certamente um sofrimento [...] Cheguei a um ponto em que não me agarro já à vida, mas levo comigo todos os apetites e a titilação insistente do ser. Já só tenho uma actividade, refazer-me (Artaud, 1991: 61).

'Refazer-me', eis a prática de cada dia, uma necessidade alquímica, vital. Prática revolucionária, micropolítica ${ }^{34}$, cuja anarquia gerencia seu lugar no mundo, equilibrando-se à borda da loucura. A criação, dessa forma, é o território desta prática, da busca de uma presença de si, transformada, num corpo a corpo com a linguagem, com as instituições, consigo mesmo: crueldade. Se esta é um apetite de vida e sua via requer rigor, pensamento engajado e uma corporeidade que intenta evitar uma estratificação e segmentação absoluta, como pode revestir-se disso uma vocalidade para a cena? Uma voz cruel, como corpo cruel, como prática da afirmação, como uma potência nômade sempre em vias de acessar o que está imperceptível ou embrenhado nas fronteiras.

Mesmo em silêncio Artaud aparentava gritar, um grito que se convulsionava a ser no jorro da voz, em vias de precipitar o demônico, devires cada vez mais intensos. Há um léxico relacionado às manifestações de Artaud que, em seus escritos, vão ao encontro de uma violência no enunciar: grito, urro, um sofrimento que quer se fazer voz, uma voz delirada, vulcânica, explosão, impacto da palavra, suscitando a audição. É como se um som quisesse se

\footnotetext{
${ }^{34}$ Para Deleuze e Guattari "Do ponto de vista da micropolítica, uma sociedade se define por suas linhas de fuga, que são moleculares. Sempre vaza ou foge alguma coisa, que escapa às organizações binárias, ao aparelho de ressonância, à máquina de sobrecodificação" (1999: 94). Aquilo que parece dado, formado e visível na esfera macropolítica, se faz pela confluência de linhas finas, muitas vezes imperceptíveis, na esfera micropolítica. E se tudo é política, como dizem estes autores, há uma política dos corpos, com seus micro-humores, micro-estatutos, micro-estratos vocais, micro agenciamentos,,..
} 
fazer presente na escrita e, para além desta, uma voz reivindicasse seus subterrâneos, sua potência não estratificada, sua sonoridade capaz de afetar o outro naquilo que apela aos sentidos primeiramente. Uma voz agressivamente tátil. E como tocar as muitas camadas embebidas por esta voz? Multiplicada em seus escritos, com contornos distintos nas diferentes fases de sua vida, esta voz ganha uma textura muito singular nos últimos anos dela.

Esta foi a fase asilar mais aguda em que as alucinações místicas explodiram os limites de sua criação, em que seu sofrimento atingiu níveis insuportáveis, com intensidade tal, que a experimentação de limites deu-nos um material denso, amplo de reflexões, prenhe de uma singular imersão. Aníbal Fernandes evidencia o grau de desestruturação sofrida por ele:

Preenchia o tempo com rituais destinados a expulsar entidades provisórias $e$ não vivas, embora animadas por imitação, veio ele a escrever nessa altura, tentando explicar a luta que travava perante a incompreensão dos médicos. Foram meses de assobios, cantos, escarros, gesticulações insólitas, espelho de uma agitação incontrolável, aquela que levou à decisão de o submeterem a electrochoques, ou seja, à passagem de uma corrente eléctrica na zona frontal da cabeça, que o deixava em convulsões e depois no vazio de uma apaziguada confusão mental (2007: 57, grifo do autor).

A noção do que pode a voz a partir de Artaud tem nesse período o ponto nevrálgico para sua discussão. Não se trata aqui de compaixão ou de uma ode ao martírio, mas da contextualização em que linhas de fuga tornaram-se possíveis para um devir singular. Reminiscências de uma cartografia: na política dos corpos em seus movimentos em relação a outros corpos, uma voz se fazia sugerir. Antes mesmo de um contexto histórico, creio tratar-se de um contexto cósmico, à maneira de uma proliferação de devires como hecceidade como entendia Deleuze e Guattari, pois é todo um conjunto de corpos e práticas como o quarto de asilo, os cadernos escritos, os amigos, o láudano, o Dr. Ferdière ${ }^{35}$, as normas psiquiátricas, as traduções de Lewis Carrol, as passarelas de Ivry e Rodez ${ }^{36}$, que perfaziam a individuação, que não é a de um sujeito, de uma coisa ou de uma substância, mas são "acontecimentos em agenciamentos que não se separam de uma hora, de uma estação, de uma atmosfera, de um ar, de uma vida" (Deleuze; Guattari, 2005: 50). Este é o movimento político do cartógrafo.

\footnotetext{
${ }^{35}$ Médico-diretor do asilo de Rodez, com quem Artaud trocou cartas e manteve uma relação singular. Essa ligação redimensionou a crítica e o embate diante do poder da instituição pisiquiátrica.

${ }^{36}$ Asilos franceses em que Artaud esteve internado.
} 
Embora Artaud não tenha escrito algo voltado exclusivamente para a vocalidade em performance, a multiplicidade de camadas do corpus de sua obra, contribui para uma poética de um devir vocal. É sob as emanações de uma consciência eletrocutada, das alucinações medicamentosas, de um homem esmagado e confrontado pela instituição médico-psiquiátrica, de um período extremamente estressante e desagregador, que ele experimentará os limites de uma criação única, portadora de uma subversão luzidia capaz de oferecer o lume para um nomadismo vocal. Trata-se dos limites de uma vida, que são os limites de uma arte, de uma escrita, de uma voz. Para Sontag "Artaud é um dos maiores e mais intrépidos cartógrafos da consciência in extremis" (1986: 55).

Uma voz sugerida é preciso ser imaginada. Quase nada parece ser apreensível ao ler Artaud, mas ao possibilitar uma minúscula fresta, algo incandescente faz-se passar, usurpando nosso conforto e instituindo uma perturbação. Há mais que palavras ali, há mais que literatura, e daí uma necessidade de ouvir vozes, uma legião delas, uma manobra da imaginação, um deviresquizofrênico na leitura. Dessa forma, sua compreensão é povoada por uma afetação, pois suscitado por uma pulsão eu não levo os conhecimentos de Artaud adiante, levo a experiência de ser atravessado e fazer atravessar. $\mathrm{O}$ que se fez agenciar em sua obra tem a profusão de uma inquietude radical de múltiplos contextos e sucessivas explosões: pode-se não ouvir um laivo de selvageria, ao menos en passant? Estas perturbações ressoaram em sua criação, em sua prática vocal e, imaginar um contexto assim, é imaginar e vislumbrar um conjunto de práticas e mutações no devir de uma vocalidade possível.

Parte de uma vocalidade sugerida em Artaud é perpassada pelo espectro do grito. Homem ruidoso, estrépito. Gritar tem na sua etimologia um pedido de socorro, no entanto ele vai além, e seu rugido corrobora com uma prática rumorosa, do latim rumor, barulho, ruído, em favor da afirmação. Grito e afirmação. O grito atravessa a instituição hospitalar, psiquiátrica, asilar, que não dão alento aos seus conflitos, atravessa a língua, em que a palavra, muitas vezes domesticada ou moralizada, não cabe certa selvageria do ato criativo, atravessa criando uma perturbação necessária, incômodo furor. O ruído entre as palavras, o ruído das crises, o ruído de uma linguagem se desmoronando, os ruídos da mente. O grito traz uma fealdade e uma violência amoral. Explosão. Um bicho nervoso, uma estética mal acabada, nada de refinamento, sem elegância. Para Artaud: 
Ninguém mais sabe gritar na Europa, e especialmente os atores em transe não sabem mais dar gritos. Quanto às pessoas que só sabem falar e que se esqueceram de que tenham um corpo no teatro, também se esqueceram de usar a garganta. Reduzidas a gargantas anormais, não é nem mesmo um órgão mas sim uma monstruosa abstração que fala: os atores, na França, agora só sabem falar (1999: 160).

Há um tom político nesta fala, pois ela aponta para um ímpeto rebelde, cuja resistência procura invadir as moralidades e desestabilizar o lugar do texto e o lugar da voz em determinado contexto. Mas também pode ser a liberação de demônios que incitam os demônios alheios. Trata-se de um grito existencial. Dar passagem às possibilidades de mutação.

Mas enfim, o que é um grito? De certa forma ele é uma violência extrema, pois ele alcança e afeta pela via do impacto sonoro desmedido ou ainda, pelo excesso de silêncio, em que se percebe que algo está para transbordar, que um vulcão está prestes a entrar em erupção, mas não se escuta nada, ao mesmo tempo uma violência absurda na ausência do som processa conteúdos com intensidade. Implosão. Este é um grito sufocado, ensimesmado, o corpo todo opera uma convulsão. Afeto molecular. $\mathrm{O}$ grito pode ser, pois, uma descarga, ainda que represada, é conteúdo informe, deformado e deformante por um ímpeto instintivo, é aquilo que também precisa ser dito e ouvido. A passagem do selvagem. Liberação. Para além do doméstico. Reverberação da matéria.

Para Silveira Bueno (1964), há uma possível origem onomatopeica de gritar (critare), estalo da língua, crepitar, uma espécie de violência ou instabilidade em staccato, atrito ritmado. A voz com seus impropérios, seus desatinos, sua desmesura, descabimento, deselegância, descompasso, o ruído como presença. Voziferação. Com o grito a matéria sofre uma anomalia: pode estourar os tímpanos, toca a nuca com maior intensidade, afasta o predador, estilhaça o vidro, acorda os vizinhos, comprime o coração, aperta o plexo, faz as lágrimas derramarem e, quando não vocalizado ou não liberado de alguma forma, algo implode, implicando uma depressão, corrompendo a matéria, desintegrando-a. O grito faz transbordar, ele é uma espécie de transbordar.

Artaud passava horas a fio, dias de prática, gritando suas sílabas inventadas, ritmando uma liturgia pessoal. Rumorando despalavras, ele tateava, com rigor, formas possíveis de um ritmo vocal. Imagino as centenas de cadernos manuscritos, imagino estes cadernos fechados, pulsando, imagino que alguém os abre, que alguém os lê, que alguém comece a escutar algo, 
pois seus cadernos falam, há uma profusão de gritos na escuridão de seus cadernos fechados, há uma agonia e um desespero da linguagem a serem desvelados. Artaud realmente deveria ser lido em voz alta, experimentando limites. Talvez sua leitura só faça sentido se escutarmos algo ruidoso, ainda que em nossa imaginação. Um livro impresso traz uma limpeza sígnica que se reconfigura com a imaginação, mas a letra de Artaud já trazia consigo uma possibilidade clara de espanto e sujeiras declaradas: rabiscos vocais. Artaud: quase um vivo entre nós, quase sangue em suas palavras, quase uma carne, um corpo se revirando, palpitando as falanges dos dedos enquanto se folheia seus cadernos.

O que grita parece cheio, como uma glossolalia que em muitos contextos é alvoroçada, catártica, excessivamente rumorosa, vazamento de algo, linha de fuga, como necessidade de escorrer-se de um métron vocal, uma manobra inaudita das práticas enunciativas. Ela é transbordamento. Rumor. Excesso. Estrépita. Ruído. Explosão. Uma voz nômade, aqui sugerida, quer correr, proliferar em múltiplos sentidos, evadir os significados de si. Ser sentido por si enquanto voz própria, não roubada pela língua, ou por deus, ou pela coerção psicanalítica, psiquiátrica ou qualquer outro roubo que a impossibilite de dizer-se a si mesma. De qualquer forma, o grito aqui não é visto como simples recurso vocal, mas como possibilidade conceitual de uma vocalidade.

Remeter e imaginar a situação asilar de Artaud, seu sofrimento extremo, seu psiquismo perturbado, seus vícios e abstinências, é situar uma violência singular no investimento do seu desejo na eclosão de fronteiras do ato criativo. É, também, pontuar uma ousadia irrefreável, que tem no grito e na inevitabilidade de experimentar, o caráter das transformações que Artaud fez sofrer a arte, a língua e a possibilidade de uma voz. É neste terreno perturbado e perturbador, de difícil digestão, que ele possibilitará uma obra em que uma voz arredia, subterrânea, movediça e intensa de fecundar com outros territórios, estará sugerida como potência virtual. Esta é a cena, como veremos, em que uma noção de corpo, o corpo sem órgãos, tomará uma forma mais evidente e necessária, em que a crueldade será exercida com seu maior rigor, em que a noção de subjétil, apontada por Derrida, será levada aos limites da sua criação, no corpo a corpo com a linguagem. É este o campo em que a glossolalia teve a possibilidade de precipitar-se em seu discurso. Que tipo de corpo será necessário para se investir numa voz passível de fazer alianças com o desconhecido? Para Artaud este corpo intensivo se opõe à ideia de organismo, a uma estratificação absoluta e à significação. 


\section{theatrum vita philargica}

Artaud não falou diretamente de uma prática vocal, de métodos ou formas aplicáveis para a voz em performance. Em 'Um atletismo afetivo', texto de 'O teatro e seu duplo' (1999), ele pontua alguns princípios genéricos sobre a respiração para uma prática baseada na Cabala. Ele via nesta prática um potencial mágico para a palavra em performance, pois acreditava no poder da entonação como em fórmulas litúrgicas, que supostamente agiam sobre a realidade e a materialidade da cena. As leituras que ele fez do ensinamento cabalístico do Zohar vai impactar substancialmente na produção da última década de sua vida, sobretudo, nos últimos anos. Susan Sontag aborda a atenção dada por Artaud ao som e forma das palavras, enquanto distintas do seu significado, referindo-se à Cabala. E, analisando os escritos deste período, ela comenta práticas que transformariam a abordagem da palavra:

[...] Passagens de argumentação, claras apesar de febris, alternam-se com passagens nas quais as palavras são tratadas primariamente como matéria (som): elas possuem um valor mágico. [...] O compromisso de Artaud com o valor mágico das palavras explica sua recusa à metáfora como o modo principal de transmissão de significados em seus últimos poemas. Ele insiste em que a linguagem expresse diretamente o ser humano físico. A pessoa do poeta aparece decomposta, num estado que ultrapassa a nudez (1986: 50).

Uma noção profunda do corpo e da matéria da vida vai impregnar todo o pensamento de Artaud, toda sua obra, entre desenhos, escritos e performances, até o limite da crise do significado, da própria possibilidade de se dizer algo, do próprio sentido que a língua pode dar às enunciações. Numa imersão na obra do francês, Sontag fala de uma "voz e uma presença inadmissíveis" (ibidem: 57), como cartografias que dão formas singulares ao incompreensível e, ao dizer que "As partes ininteligíveis dos últimos escritos de Artaud devem permanecer obscuras - serem diretamente apreendidas enquanto som" (ibidem: 51), aponta para um aspecto peculiar de uma enunciação glossolálica.

A prática cabalística entre outras tradições iniciáticas investiram na pluridimensionalidade da enunciação. A ininteligibilidade de uma fórmula secreta fazia reverberar uma matéria plástica no contato com o som da voz, rememorando o poder do verbo primordial em vários mitos da criação do cosmos. Alessandra Pozzo diz que: 
Secreto e iniciático um conhecimento paralelo ao saber conceitual, segundo o qual as palavras, ou bem, certas palavras, tem um poder independentemente do seu significado, se manteve ao longo dos séculos. Seguindo esta perspectiva, a palavra falada não constitui apenas um instrumento para significar ou comunicar, mas ela permite agir sobre as coisas segundo uma representação da palavra como força real. Esta crença, que se funda sobre um equivalente entre as palavras e as coisas, constitui o fundamento de toda prática mágica verbal (2013: 219, tradução nossa) ${ }^{37}$.

Estes princípios farão parte de um conjunto de práticas que fizeram brotar as glossolalias em Artaud. Apoiado em termos como fisiologia, vibrações, afetivo, sentido material, materialidade fluídica, flutuações plásticas da matéria, obsessão física, músculos, ossos, ele dará aos sentidos e à fisicidade cênica o caminho para a manifestação do afeto e do sentimento, pois "toda emoção tem bases orgânicas" (Artaud, 1999: 160). O princípio cabalístico é afeto à esta materialidade, pois pretende uma transmutação através do poder criador da palavra enquanto voz, enquanto som. Trata-se também de alguns princípios gerais sobre o poder que a qualidade da respiração pode exercer no trabalho do ator e, da necessidade de se desenvolver um atletismo afetivo, que corresponderia a uma prática de consciência aplicada à dinâmica corporal, num "apossamento orgânico", "conhecimento físico" de uma "musculatura afetiva", passível de tornar o ator um "atleta do coração" (idem). A noção de um corpo e uma apropriação sensível da prática do ator aliada à respiração, sopro da vida, origem plástica de qualquer enunciação, são aspectos que, incubados antes do longo período de internação de Artaud, ganhará contornos distintos para uma poética vocal que será desenvolvida, ou melhor, sugerida mais à frente.

Neste período, sua noção de linguagem física da cena que consistia "em tudo o que ocupa a cena, em tudo aquilo que pode se manifestar e exprimir materialmente numa cena, e que se dirige antes de mais nada aos sentidos em vez de se dirigir em primeiro lugar ao espírito, como a linguagem da palavra" (ibidem: 37), já anunciava uma voz insatisfeita com os limites linguísticos da palavra e desejosa de uma outra substância sonora capaz de movimentar o sensorial. A presença cênica é, sobretudo, concreta. Há um apelo atômico, molecular, tátil, do espaço da performance. A Contingência da matéria é um plano que, primariamente, agrega

\footnotetext{
${ }^{37}$ "Secrète et initiatique, une connaissance parallèle au savoir conceptuel selon laquelle les mots, ou bien, certains mots, ont un pouvoir indépendant de leur sens s'est maintenue tout au long des siècles. Suivant cette perspective, la parole ne constitue pas seulement un instrument pour signifier ou communiquer, mais elle permet d'agir sur les choses selon une représentation du mot comme force réelle. Cette croyance, qui se fonde sur une équivalence entre les mots et les choses, constitue le fondement de toute pratique magique verbale".
} 
um valor direto na percepção do performer e do espectador. As inquietações de Artaud iam de encontro ao sentido psicológico, geralmente determinado ao texto, que há época tinha no diálogo o sentido condutor da experiência cênica. Vislumbrava além dos limites de uma literalidade do discurso dialógico, um teatro de emanações físicas, pois "essa linguagem que evoca ao espírito imagens de uma poesia natural (ou espiritual) intensa dá bem a ideia do que poderia ser no teatro uma poesia no espaço independente da linguagem articulada" (ibidem: 39).

O apelo a uma concretude cênica passa pela necessidade de que a voz esteja imbuída deste caráter material e sensível, não necessariamente vinculada à palavra, mas principalmente apoiada na sonoridade, entendamos aqui, nos parâmetros do som, como é abordado em outras sessões dessa pesquisa. Ainda sobre o valor de uma cena que, cruelmente, perturbe a partir dos sentidos do espectador, ele diz que

[...] essa linguagem concreta, destinada aos sentidos e independente da palavra, deve satisfazer antes de tudo aos sentidos, que há uma poesia para os sentidos assim como há uma poesia para a linguagem e que a linguagem física e concreta à qual me refiro só é verdadeiramente teatral na medida em que os pensamentos que expressa escapam à linguagem articulada (ibidem: 36).

A linguagem articulada, a palavra em seu sentido gramatical, o diálogo em seu contexto psicológico, atores que só sabem falar, mas não sabem gritar, são termos, aqui já tratados, que vão de encontro a um ideário sobre a materialidade da cena pretendida por Artaud. Suas ideias apontam para os desígnios de uma voz outra. Que voz é esta? E outra vez: o que pode esta voz? Estas noções, cujos princípios ganham maior evidência em 'O teatro e seu duplo' (1999), antecede e alimenta o contexto asilar dos últimos anos de sua vida. Importante deixar claro que estou percorrendo um caminho que culminará na morte de Artaud e, neste trajeto, uma noção de corpo e de voz sofrerá, processualmente, transformações importantes. Todos estes conceitos sobre o que seria uma materialidade cênica em Artaud foram forjados num contexto muito diferente do contexto manicomial e asilar, pois a realidade das internações psiquiátricas possibilitaram-no uma imersão na escrita, no universo dos desenhos e elocuções solitárias, o que o distanciou circunstancialmente das possibilidades da cena e de um público teatral, assim como de uma vida pública no meio intelectual francês. 
Este devir fez repercutir uma noção de crueldade que ganhou outro status ao longo do tempo, fazendo precipitar uma noção de corpo sem órgãos, e de uma voz gestada e parida na convulsão deste período. Uma hecceidade: a vida de Artaud. Distante dos espaços de encenação, seu desejo proliferou por outras linhas de fuga. O próprio conceito de subjétil será evidenciado na intensa prática de desenhos, chamada por Derrida de pictografias, e o material textual produzido em Rodez. As ideias de Artaud também não seguiram uma cronologia e uma linearidade claras, pois acompanharam as disparidades e idiossincrasias de seu estado mental ao longo da sua vida, mas apontaram o amadurecimento de conteúdos que, investindo energia contra uma noção de corpo, de deus, de linguagem e de muitas outras instâncias, fomentaram uma prática glossolálica.

'Para acabar com o julgamento de deus' foi uma obra criada no limiar da morte, depois de longos anos de internação. E não foi por acaso que a performance deste texto foi chamada por ele de teatro da cura cruel, tão como foi o território de incubação do corpo sem órgãos. Num insigth incandescente Artaud enuncia:

Levando-o uma vez mais, uma derradeira vez, à mesa de autópsia para lhe refazer a anatomia./O homem é doente porque é mal construído./Temos que nos decidir a desnudá-lo para lhe extrair esse animalzinho que mortalmente o corrói, deus e juntamente com deus os seus órgãos./Porque metam-me se lhes apraz numa camisa de força mas não há nada mais inútil do que um órgão./Quando lhe conseguirmos um corpo sem órgãos tê-lo-emos libertado de todos os seus automatismos e restituído à sua verdadeira liberdade (1975: $50)$.

Autópsia existencial, legado vocal de Artaud para a posteridade, uma obra curtida nos asilos, adubada com profundas reflexões sobre a teologia cristã, delírios místicos e uma sensação, inquietante, de uma voz amoral. Na filosofia de Deleuze, o corpo, neste contexto artaudiano, não poderia ser uma organização submetida aos poderes institucionais de deus. Este funcionava como o usurpador de um corpo intenso, a-significante, imerso numa micropolítica do desejo. Deus era o ladrão desse corpo. Quem era deus? O que é um órgão? O que se investe na noção de organismo? O que seria o corpo sem órgãos supliciado por Artaud?

Deus, como um princípio ordenador da política dos corpos e da política da vida, é aquele que detém o juízo, o poder de julgamento. Assim, somente um corpo transformado em organismo com sua divisão clara, objetiva e conveniente, pode ser julgado a partir de uma noção fragmentária em que o desejo segue a uma coerção, uma coerção cultural, coerção 
psicanalítica, coerção religiosa, coerção fundada nos poderes investidos em instituições. Neste caso, o desejo soa como falta. Como transita o desejo num corpo assim organizado? Ele segue um fluxo de estratificações, ele não experimenta, ele serve ao experimento, no sentido em que sua função social, política, econômica, anímico-espiritual ou qualquer outra função arbitrária, segue a determinação de territórios em que o movimento, como potência nômade, encontra obstáculos para experimentar e pactuar, barreiras para criar, limites para afetar e ser afetado, pois um corpo estratificado não pode ser um gradiente de intensidades cujo desejo povoa com certa liberdade.

Um órgão é investido de funções, há uma domesticação política e moral de seus atributos e do seu alcance. Se de um lado o medo é fascista, julga e é julgado, e estabelece uma política de cerceamento, como apontava Deleuze e Guattari, o desejo, diziam eles, é revolucionário, pois "nenhuma sociedade pode suportar uma posição de desejo verdadeiro sem que suas estruturas de exploração, de sujeição e de hierarquia sejam comprometidas" (2011: 158). Estes autores analisam a crueldade como uma forma de potência desejante que opõe-se à doutrina teológica do juízo no nível dos corpos, pois

[...] o juízo implica uma verdadeira organização dos corpos, através da qual ele age: os órgãos são juízes e julgados, e o juízo de deus é precisamente o poder de organizar ao infinito. Donde a relação do juízo com os órgãos dos sentidos. Inteiramente outro é o corpo do sistema físico; ele se subtrai tanto mais ao juízo quanto não é um "organismo", estando privado dessa organização dos órgãos pela qual se julga e se é julgado...Artaud apresenta esse "corpo sem órgãos" que Deus nos roubou para introduzir o corpo organizado sem o qual o juízo não se poderia exercer (2004: 148).

O que fazer transitar neste corpo? O que se passa? O que não se passa? O que impede que o desejo o atravesse? A experimentação destes limites é o que dá sentido afetivo na criação de um corpo sem órgãos para si. Trata-se de uma busca, ela não cessa, pois não se chega até lá, devir contínuo de uma vida: "Encontre seu corpo sem órgãos, saiba fazê-lo, é uma questão de vida ou de morte, de juventude e de velhice, de tristeza e de alegria. É aí que tudo se decide.” (Deleuze; Guattari, 1999: 11), há sempre um limite, e outro, e outro, e outro, sobre os quais incidem um conjunto de práticas.

Se o nível do corpo, em Artaud, combate sua própria estratificação e reivindica uma singularidade no investimento de desejo, a voz não poderia ser um órgão partindo de um corpo assim, ao menos não se contentaria em ser um órgão, não poderia ser uma boca, um 
diafragma, uma laringe, um nariz, pulmão, respiração-órgão, ar-objeto. Também não poderia ser a organização destas partes, ela abarcaria algo além da articulação do aparelho fonador com seus apoios, seus princípios técnicos e suas formas possivelmente codificadas. Dessa forma, uma noção de voz nômade, aqui pretendida, teria maior consonância com a pergunta, sempre a pergunta como um motivo sempre recorrente e sempre renovado: O que pode a voz? O que pode a voz num corpo sugerido por Artaud? Isto implicaria um conjunto de práticas de desarticulação, dessubjetivação e a-significação como apontam Deleuze e Guattari.

A voz de Artaud se manifestou numa miríade de formas revolvendo estratos como a loucura, a língua, a escrita: no corpo a corpo com instituições como o juízo da perícia psiquiátrica, procurou a via radiofônica para uma manifestação sonora idiossincrática, buscou os grunhidos, cantos, murmúrios e balbucios em quartos de asilo, derramou-se sobre os textos se alastrando como uma peste, agrediu e foi agredida pelos limites da linguagem... num corpo vasto, experiencial, numa vitalidade não-orgânica como chamou Deleuze, pois "A vitalidade nãoorgânica é a relação do corpo com forças ou poderes imperceptíveis que dele se apossam ou dos quais ele se apossa [...]" (2004: 149).

Um pacto com o diabo soa, vibra, como uma alternativa. Impurezas e idiossincrasias da voz, o anômalo à espreita, aguardando o reverberar do desejo, numa voz afetada e deformada, difusa nas multicamadas dos fenômenos de borda. Ela blasfema, grita, xinga, faz um manifesto desmedido de si, faz as palavras se perderem, traz a brutalidade do som, também a suavidade dentro dele, ela pede e pode algo mais e é a este algo que se volta esta entrega. Buscar um corpo em que a "experimentação substitui toda interpretação da qual ela não tem mais necessidade" (Deleuze; Guattari, 1999: 25).

Falar de um corpo sem órgãos em Artaud, a partir de Artaud, exige a noção de uma configuração explosiva de elementos como a loucura e sua dimensão psiquiátrica vivenciada por ele, o vício do ópio, do láudano e dos entorpecentes clínicos, viagens místicas, infindos projetos fracassados, e uma imersão profunda nas angústias existenciais de um homem que enxergava o obscuro de sua contemporaneidade. Considerando o fato de que o corpo sem órgãos não pára de oscilar entre as superfícies que o estratificam e o plano que o libera como apontam Deleuze e Guattari, importante notar que, no caso de Artaud, evidenciava-se muito mais o lado liberador dessa experiência: linha tênue entre uma lucidez excessiva e uma loucura declarada. 
Um corpo em devir em práticas de experimentação: Artaud em combate. O grande estrato de deus e os embates entre suas fissuras em rotas de fuga. O combate-entre "trata de apossar-se de uma força para fazê-la sua [...] é o processo pelo qual uma força se enriquece ao se apossar de outras forças somando-se a elas num novo conjunto, num devir" (Deleuze, 2004: 150), dessa forma, Artaud reivindicava seus próprios planos de criação, seu próprio artifício, sua própria voz, no intento de ser um demiurgo de si. Linhas de fuga em relação à expropriação divina.

O organismo, a significância e a subjetivação são os grandes estratos gerais apontados por Deleuze e Guattari, contra os quais vai se opor uma noção de corpo sem órgãos. Numa política do desejo, o organismo deve ser desarticulado, a não-interpretação segue os princípios de uma prática a-significante e o nomadismo desestabiliza as buscas de identidade do sujeito. Artaud desarticulou-se até perder-se por completo no fogo da insensatez? Sucumbiu à experiência de criar pra si um corpo sem órgãos? Acredito que ele experimentou os limites do que Deleuze e Guattari chamaram de arte das doses em relação ao perigo da overdose.

Artaud bem poderia ter vivenciado uma prática de desarticulação em que sua consciência teria sucumbido à loucura de uma forma inevitavelmente desagregadora e destrutiva, tendo na autodestruição sua pulsão preliminar. Mas sua coragem, princípio primeiro da prudência ${ }^{38}$ aqui tratada, possibilitou uma obra rica e inesgotável. Embora estes limites ainda possam ser discutidos num sentido de qualidade de vida e longevidade na trajetória de Artaud. De qualquer forma, para o performer, para o artista, é fundamental não sucumbir ao desvario, é saudável vislumbrar o limite, é sensato não morrer. Para isso a prudência, princípio básico da criação, é, para Deleuze e Guattari, a instância agregadora que dará ao corpo sem órgãos a possibilidade de criação, trânsito do desejo, e um gradiente de intensidades, sem que ele se destrua e pereça por uma overdose desmedida. Lançar-se ao furor, ao risco de vivenciar limites, acessar o anômalo, fazer alianças com processos obscuros nas fronteiras, sem corromper a integridade da criação que também é a integridade de si.

\footnotetext{
${ }^{38}$ A prudência, para Deleuze e Guattari, é a arte comum das práticas que agem sobre os estratos da significância, da articulação e da subjetivação. Para eles "Desfazer o organismo nunca foi matar-se, mas abrir o corpo a conexões que supõem todo um agenciamento, circuitos, conjunções, superposições e limiares, passagens e distribuições de intensidade, territórios e desterritorializações [...]" (1999: 22). Dessa forma, o conjunto de práticas que efetivam um corpo sem órgãos deve ser exercido pelo princípio da prudência, investindo em desejos que não se confundem com a destruição e desagregação de si.
} 
E ao organismo, primeiramente, Artaud vai opor a desarticulação. A operação de desfazer-se para rearranjar-se em configurações singulares, não uma configuração do juízo divino. Tratase antes de um atomismo fazendo suplantar uma anatomia:

Quem sou eu? / Donde venho? / Sou Antonin Artaud / e mal digo isto / como só eu o sei dizer / imediatamente / vereis o meu corpo actual / voar em estilhas / e refazer / sob dez mil formas / notórias / um corpo novo / no qual jamais / me podereis / esquecer (Artaud, 1975: 65).

Sua corporeidade posta, guarda sempre uma potência virtual em vias de se atualizar, fazendo fugir-se da organização do juízo. Derrida fala sobre este processo de desarticulação como desejo que se volta contra o fenômeno da expropriação:

Mas antes de corromper a metafísica do teatro, o que designaremos como a diferenciação orgânica tinha feito devastações no corpo. A organização é a articulação, a junção das funções ou dos membros..., o trabalho e o jogo da sua diferenciação. Esta constitui ao mesmo tempo a compleição e o desmembramento do meu (corpo) próprio. Artaud teme o corpo articulado tal como teme a linguagem articulada, o membro como a palavra, dum único e mesmo jato, por uma única e mesma razão. Pois a articulação é a estrutura do meu corpo e a estrutura é sempre estrutura de expropriação. A divisão do corpo em órgãos, a diferença interna da carne abre a falha pela qual o corpo se ausenta de si próprio, fazendo-se assim passar, tomando-se por espírito. Ora, "não há espírito, apenas diferenciações de corpos" (3-1947). O corpo que procura sempre se reunir" escapa a si próprio por aquilo que lhe permite funcionar e exprimir-se, escutando-se, como se diz dos doentes, e portanto despistando-se de si próprio (2009: 275).

Percebemos aqui que a articulação do organismo é uma estratificação que opera em várias camadas, como a do corpo e a da linguagem. Assim como a significância e a subjetivação. Se formos tentar traçar uma cronologia de significâncias na obra de Artaud, perceberemos um grande contrassenso, pois ela resiste violentamente à interpretação. Sontag comenta uma noção de linguagem em Artaud, que esforça-se para dizer o indizível:

A linguagem que Artaud utilizou no final de sua vida, em passagens de Artaud, o Momo, Aqui Jaz, Para Acabar com o Julgamento de Deus, está às raias de um discurso declamatório incandescente para além de todo o sentido. "Toda verdadeira linguagem é incompreensível", diz Artaud em Aqui Jaz (1986: 51, grifo do autor).

Estas práticas de a-significação tornavam o discurso poroso às cintilações de ruídos e à profusão de imagens. Artaud experienciou bem os limites da língua na intersecção com outras 
linguagens. Povoava aí, às bordas de suas experiências, uma glossolalia marulhosa, na incubação de sonoridades desgarradas.

Se, ao procurarmos uma homogeneidade do discurso e a fixação de interpretações em Artaud somos confrontados muitas vezes com o que parece ininteligível e inclassificável, na busca por uma identidade, ele também faz sucumbir tal tarefa. O milagre da multiplicação de Artaud. Para além do clichê de que não sou o mesmo nunca, trata-se antes de um movimento nômade consciente de desestabilização do sujeito, pois não há um 'eu digo' e sim uma legião, uma matilha, um coletivo, que explora o eu que vacila. Há um coletivo na voz, uma polifonia. Numa carta a Paulhan, Artaud diz "Eu não quero mais assinar de jeito nenhum" (Mèredieu, 2011: 57), numa afronta direta ao princípio da identidade. Transubstanciou-se em Cristo, rei dos reis, criando linhagens de reis que fez habitar sua figura; foi Artaud Nalpas, Artaud, o Mômo, Arland Antoneo, em grego Arlanpulos; buscou mudar o nome numa mística iniciática... ${ }^{39}$

Limiar da loucura ou loucura de fato? A verdade é que ser outro estava, também, na confluência de alguns acontecimentos: entorpecido por narcóticos ou na abstinência deles, na desagregação de eletrochoques, no território do performativo, nos insigths iniciáticos. As atualizações de muitos Artauds flertava, de fato, com uma liberação desmedida, zona dos combates-entre, na flutuação da consciência. Onde desaguou Artaud? Estas experiênciaslimites fizeram transbordar o quê? Os fluxos de desejo que ele fez passar por seu corpo sem órgãos pactuaram sempre com a arte das doses? Referindo-se a todas as contingências que implicam a criação de um corpo sem órgãos, Deleuze e Guattari sentenciam: "Mesmo que Artaud não tenha conseguido para ele mesmo, é certo que através dele algo foi conquistado para nós todos" (1999: 27).

A perícia médico-psiquiátrica diagnosticou-o por vezes como alienado, drogado e até canceroso, possível motivo de sua morte, se é que se pode falar de uma causa mortis de uma pessoa envolvida num campo tão complexo de desequilíbrios afetos não só à saúde, mas à existência. Derrida analisa uma terceira via que foge ao discurso clínico e ao discurso da obra em Artaud, possibilitando uma leitura simultânea destes dois discursos como um acontecimento que não se situa nestes estratos: "em primeiro lugar porque este acontecimento

\footnotetext{
${ }^{39}$ Ao longo de suas internações, Artaud deu-se vários nomes, apelidou-se, acreditou ter vivido como outros, multiplicando-se numa variedade de personas. Ver sua biografia escrita por Mèredieu (2011).
} 
é o do demônico que se mantém fora da oposição doença-saúde" (2009: 253). O demônico aqui é uma potência em Artaud, ele se encontra fora dos sistemas e fecunda com as fronteiras, os entres que fazem pulular as experiências. Novamente os princípios desconcertantes de um pacto com o diabo. Derrida, como meio de transcender questões como tratar a obra de Artaud como fruto de uma patologia de forma a separá-las ou uni-las em favor de uma unilateralidade, defende a experiência enquanto devir do artista:

Pois o que os seus urros nos prometem, articulando-se com os nomes de existência, de carne, de vida, de teatro, de crueldade, é, antes da loucura e da obra, a existência de um artista que não é mais a via ou a experiência que dão acesso a outra coisa além delas próprias, de uma palavra que é corpo, de um corpo submetido a uma escritura mais antiga do que ele, a algum arquitexto ou arquipalavra (2009: 257).

Apontando para além de si mesmo, essa experiência em Artaud revelava uma poética do excesso. A crueldade fazia transbordar uma exigência radical da vida, nascida e curtida na abundância. Camille Dumoulié que aproxima a vontade de poder de Nietzsche à crueldade de Artaud, fala do princípio do excesso como aquilo que nos coloca numa relação mais íntima com a realidade. Dessa forma, a crueldade tem um compromisso com a singularidade, de forma a revelar atos que são arbitrariamente condenados socialmente, mas que, de fato desvela o excesso do outro em si. Dessa forma, para Dumoulié:

\begin{abstract}
A crueldade é portanto um sinal do excesso, como pensava Aristóteles, mas o excesso seria a cruel exigência da existência humana. Apenas a maneira como o homem, não só como indivíduo, mas também socialmente e culturalmente, acolhe esta dimensão do excesso, que é também a dimensão da alteridade nele próprio, dando à crueldade seu caráter de inocência ou de perversão (2003: 22, tradução nossa) ${ }^{40}$.
\end{abstract}

Os conflitos na busca por fazer do excesso uma dimensão necessária da alteridade fazem-se emblemáticos na figura de Heliogábalo ${ }^{41}$, cuja a existência regada a sêmen, sangue e um despudor intratável fez ressoar a tal inocência e perversão, que tanto cativou Artaud.

\footnotetext{
40 "La cruauté est donc bien signe d'excès, comme le pensait Aristote, mais l'excès serait la cruelle exigence de l'existence humaine. Seule la manière dont l'homme, en tant qu'individu, mais aussi socialement e culturellement, accueille cette dimension de l'excès, qui est aussi la dimension de l'altérité au sein du propre, donne à la cruauté son caractére d'innocence ou de perversion".

41 'Heliogábalo ou O Anarquista Coroado' (ver referências).
} 
A crueldade e um atletismo afetivo ascendendo à uma noção mais ampla e complexa de um corpo sem órgãos. Os limites, a loucura, a linguagem e toda uma necessidade de desarticulação e a-significação do discurso artístico numa vida que não se dissocia da arte. Tudo isso temperado com gritos e urros, numa vibração que apela aos sentidos primeiramente. Uma contribuição para uma materialidade viva e pulsante. Elementos cruéis, revolvidos na carne da existência. A verdade é que Artaud vibrava, ainda que não falasse, vibrava vocalmente, sua prática convergia para o dizer, seus textos ressoavam esta voz.

Os princípios da dessubjetivação, da desarticulação e da a-significação, citados por Deleuze e Guattari, preconizam a prática de Artaud numa atividade de fazer a linguagem delirar na glossolalia. Esta prática que reivindica as potências virtuais do som é uma zona intensiva em que todas as idiossincrasias vividas por Artaud procuram o exercício liberador do corpo sem órgãos, sob os princípios de uma crueldade. Em 13 de janeiro de 1947 ele fez a famosa conferência em Vieux-Colombier, um marco performático, que de certa forma assimilou a crueldade como princípio existencial em sua vida. Era Artaud ali. Nu. O que isto significa? Um homem cheio dos erros, enganos e imperfeições de uma vida atribulada, nervoso, trêmulo e, ao mesmo tempo, intenso, lúcido, incômodo. As idiossincrasias de seu lugar incerto na sociedade francesa, seu lugar como artista, seu lugar no cosmos, entregue à presença, ao improviso, às fraquezas e, sobretudo às forças, que inelutavelmente o levaram até ali.

Um ano antes de sua morte e, depois de ficar internado por 9 anos, ele se apresenta à uma plateia de convidados ilustres para uma aparição singular. Um happening? Teatro? Conferência? Um acontecimento singular numa noite em que sua performance habitou uma fronteira difícil de ser digerida pelos seus pares, entre críticos, artistas e pessoas diversas do meio intelectual francês. Havia uma falta de acabamento, certo nervosismo, um ensaio que não se sustentava e que acabou na entrega de Artaud à confusão lúcida daquele momento único. Artaud gaguejou, berrou, blasfemou, estava visivelmente magro e abatido, porém enérgico, sua força ainda era cintilante, meio caminho de uma conferência fracassada na visão de uns e viva na pele de seus dilemas existenciais para outros. Florence de Mèredieu narra o acontecido:

Foi essa promiscuidade, sem dúvida, que os espectadores da sessão não conseguiram suportar: esse face a face (e corpo a corpo) - físico - com Artaud o Mômo, esse farrapo e esse caco exatamente saído dos asilos, que vem uivar na cara de toda Paris as falas dos analfabetos. Gide e Dubuffet não 
estarão errados ao considerar Artaud uma espécie de grande Pitonisa. E é a isso que o próprio poeta retornará nos dias seguintes à conferência, em sua abundante correspondência a Breton, Maurice Saillet, a Pascal Pia. Louis Guillaume se recorda, depois de algum tempo, de ter visto Artaud, "caído em um banco, entre a fonte Médicis e a livraria Corti. Ele parecia um clochard" (2011: 899).

A coragem, intenção primeira da noção de prudência em Deleuze e Guattari, se articula aqui numa performance em que a crueldade se torna um acontecimento vivo, em que os dilemas da arte e os dilemas da existência encontram num homem um porto denso de sentidos. Esta foi uma experiência em que os limites da sandice, da indigência e da extrema lucidez, apontaram como uma enunciação contemporânea, vasta de sentidos, que estendeu-se e influenciou gerações e outras criações. Há esta época, a voz de Artaud procurava enfatizar seus experimentos com a linguagem, transcendê-la ou, ao menos, dar-lhe um outro matiz em que o som e a a-significação fossem parte essencial das possibilidades de enunciar.

Esta vocalidade sugerida, como uma zona indiscernível, procurava dar vazão a valores não domesticados, um desejo de desarticulação linguística que é uma desarticulação de si, um desejo que, encontrando barreiras para se fazer passar, entra em embate e comunga com fenômenos que estão entre, experimenta um limite, denota uma revolução, não no sentido ideológico, "mas de pura matéria, fenômeno de matéria física, biológica, psíquica, social ou cósmica" (Deleuze; Guattari, 1999: 28). Como um vinho sonoro-poético, é possível vislumbrar uma glossolalia a transbordar.

Uma voz glossolálica, como invenção e transbordamento, como resto e como excesso, tem em Artaud uma prática intensiva da crueldade. Como investimento do desejo num corpo sem órgãos, insinua-se como um território importante para práticas da voz em performance. Que estranha algaravia é essa, que excita tanto os limiares da nossa audição? 


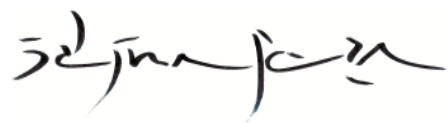

Glossolalia: palavra ampla de sentidos, estranha, historicamente mutante, conceitualmente espessa, de muitas camadas, emanação de manifestações divinas e psiquiátricas, de transes, de contornos poéticos, contraditória, fugidia, obscura,... Como prática de enunciação, ela se configura aqui, porosamente, como experiência possível no campo da performance vocal do ator e do performer, no entanto ela se relaciona e faz precipitar uma gama infinda, muitas vezes insondável, de aspectos que contribuem para uma visão sonoro-poética da vocalidade: cantos litúrgicos, fórmulas ocultistas, línguas inventadas, vaticínios oraculares, vozes de possessão, discursos ininteligíveis, jogos teatrais, entre outros. Façamos primeiramente uma viagem etimológica possível dentro de uma de suas muitas histórias, começando pelo termo em si.

Do grego glossa (língua enquanto órgão fonador, dialeto, linguagem) + lalein (verbo falar). A origem de glossa é obscura e guarda imprecisões históricas e conceituais. Me apoiarei, a princípio, nas considerações feitas por Alessandra $\operatorname{Pozzo}^{42}$ que analisa a evolução do termo glossa a partir de um estudo feito por Louis Holtz. Faço aqui uma síntese sobre suas considerações. Glossa, aparentemente e sem precisão temporal, teria sido derivada de glokes (barba de épi) ou ainda glokis (ponta), tendo o sentido de língua enquanto órgão da fonação, uma língua pontuda. A voz num sentido penetrante enquanto som e/ou discurso? Também significava a palavra pronunciada e ainda uma língua, dialeto e até a própria linguagem num sentido mais genérico. Aristóteles a designa como a palavra que se faz notar por ser estrangeira ao léxico comum e conhecido. Logo, trata-se de um termo que, intencionalmente utilizado, desestabiliza a banalidade do discurso, muitas vezes com o intuito de atrair a atenção e admiração do leitor por meio do insólito.

Um sentido que deriva daí é o de que glossa trata-se de um elemento lexical raro, seja um empréstimo dialetal, seja uma palavra bárbara ou ainda uma palavra velha, que já caiu em desuso. Para Holtz a função poética da linguagem tem na palavra glossa ou glotta a estimulação do imaginário do leitor. A palavra rara, neste sentido, comporta uma potência ligada à multiplicidade de sentidos do estranho e do insólito. Glossa, até aqui, vincula-se a um texto escrito, ao que Holtz esclarece que "Assim, a forma glôssais lalein constituiria,

\footnotetext{
${ }^{42}$ Especialista em linguagens estranhas e formas de expressão que estão na fronteira entre o signo e a língua, pesquisou o grammelot em Dario Fo e publicou o estudo 'La glossolalie en occident' (2013).
} 
verossimilmente, um sentido ligado à noção de glossa, mas transposto às formas orais específicas ao falar inspirado do início do cristianismo" (Pozzo apud Holtz, 2013: 64, tradução nossa) ${ }^{43}$.

Um sentido posterior refere-se a uma noção de glossa como uma palavra rara, não necessariamente intencionalmente colocada num texto, mas a qualquer palavra, cujo sentido insólito precisa ser explicado, criando o duplo: palavra rara e interpretação da palavra rara. Referindo-se ainda ao estudo proposto por Holtz, Pozzo sintetiza a história da noção de glossa, partindo da palavra que se faz notar em um texto porque ela é estrangeira e, logo, necessita de uma explicação, ou bem uma tradução; em seguida indica qualquer elemento lexical raro, não importa sua raridade e, posteriormente qualquer palavra rara cujo sentido necessita ser explicado. Para Pozzo "A proximidade com lalein projeta esta palavra no universo do enunciado oral, enquanto que na origem ela pertencia a de textos escritos" (2013: 64, tradução nossa) ${ }^{44}$. Logo, a glossolalia se liga a uma prática enunciativa que é marcada pela ininteligibilidade e pela necessidade de se explicar o desconhecido, sobretudo num contexto oral. Veremos adiante o quanto uma noção de glossolalia no campo artístico foi voltada para o contexto escrito, cujos territórios de investigação fizeram impactar em diversas vocalidades, como é o caso, inclusive, da prática de Artaud.

Partindo destas perspectivas sobre o termo e ampliando seu espectro semântico, podíamos pensar num discurso sonoro-vocal e na intrusão de outros sons vocais que interfiram na homogeneidade de tal discurso, pois mesmo numa algaravia de gritos com alto coeficiente de ruídos, os sons de certas vozes ruidosas podem soar desarrazoados ou fora de contexto. Até mesmo um som comportado e comedido soará estranho dentro de uma sonoridade caótica. Neste sentido e relacionando à prática performática, a palavra rara ou elemento lexical raro pode ser expandido para qualquer sonoridade vocal incomum contextualizada. Dessa forma, alguns princípios são evidenciados em diversos contextos de práticas glossolálicas: a marginalidade, a desestabilização de contextos e uma noção de ininteligibilidade e estranhamento.

\footnotetext{
43 "De ce fait, la forme glôssais lalein constituerait vraisemblablement une tournure liée à la notion de glôssa, mais transposée aux formes orales spécifiques au parler inspiré du début du christianisme".

${ }^{44}$ "La proximité avec lalein projette ce mot dans l'univers de l'énoncé oral, alors qu'à l'origine il appartenait à celui des textes écrits".
} 
Ao mesmo tempo em que a etimologia aponta alguns aspectos que serão importantes para uma noção expandida de glossolalia para a voz em performance aqui evidenciada, cabe apontar alguns elementos mítico-religiosos, linguísticos, psiquiátricos, filosóficos e poéticos ao longo de sua história, que contribuirão para a espessura do conceito e suas definições.

Como termo híbrido, fronteiriço, de difícil demarcação, ele abarca muitos campos do conhecimento como as práticas religiosas, estudos de linguagem, arte e cultura, transitando por muitos contextos. Mais comumente, a glossolalia refere-se ao falar em línguas ou dom de línguas como prática oral nas igrejas pentecostais, na descida do Espírito Santo, como manifestação da voz de Deus. A língua dos homens não comporta os desígnios celestiais, dessa forma, a apreensão do sentido se dá por uma espécie de clarividência pela sonoridade deste fenômeno, muitas vezes por meio do dom de interpretação de línguas. No entanto, a glossolalia não é um fenômeno religioso estritamente cristão, pois fazia parte de práticas pagãs, sobretudo em contextos marginais, como é o caso das práticas oraculares e outras liturgias na Grécia antiga. Demais, é um termo que foi apropriado pela psiquiatria para registros nosográficos de patologias psíquicas. Em qualquer contexto relacionado à prática glossolálica, ela sempre se relaciona com uma instabilidade, seja do discurso, seja da vocalidade, seja do texto escrito, sempre como transbordamento e excesso de um código, norma ou de uma estrutura.

Situar alguns contextos e definições da glossolalia ao longo da história servirá de base para uma consideração mais voltada para a voz em performance. Existem poucos textos em português que tratam do fenômeno glossolálico, sobretudo no âmbito da pesquisa para a voz em performance. A maior parte da literatura, incluindo a estrangeira, é voltada para o fenômeno do falar em línguas da tradição cristã. Quando o interesse é distinto desse, as pesquisas são voltadas para a área da comunicação com foco em aspectos linguísticos e semióticos. A maior parte das referências aqui apontadas são da tese de Pozzo 'La glossolalie en Occident', livro em que aprofunda o tema em diversos momentos históricos, apontando peculiaridades dentro do contexto mítico-religioso, sobretudo cristão, também no contexto e desenvolvimento da linguística e psiquiatria modernas, tão como no campo cultural, sobretudo das artes do início até meio do século XX. Recorro também a Michel de Certeau, cuja reflexão deu fundamento a Pozzo para uma definição de glossolalia no contexto artístico. 
Como território heterogêneo, cujo conceito bebe de muitas fontes e cujos recortes até parecem se contradizer, a glossolalia pode instigar com sua potência de estranhamento, sugerindo um conjunto de práticas e poéticas que em muito podem contribuir para uma discussão sobre vocalidades para a performance. Vários contextos são apontados no corpo desta pesquisa no intuito de desenvolver conexões entre essa discussão e a práxis vocal do performer. Retomando o hibridismo de um fazer desarrazoado, Jean Jacques Courtine, em seu artigo 'Les silences de la voix', fala sobre um caráter impreciso, fugidio e híbrido das glossolalias:

Dispersas às margens de instituições - eclesiásticas, clínicas, científicas ou literárias - protetoras do sentido de enunciados, vem proferir nessas práticas, a falta de sentido de produções sonoras que soam todas, ao mesmo tempo, como um desafio e um apelo à interpretação. Práticas instáveis, fluidas e intermitentes: a história das glossolalias, é a história de muitos desaparecimentos e repentinos apagamentos, mas também de bruscas efervescências, de incessantes renovações. Esta história, em grande parte, não foi escrita ainda. Fazê-la é complexo (2006: 01, tradução nossa ${ }^{45}$.

É justamente no sentido da instabilidade e da obscuridade dessas práticas que se apoiará uma noção de voz cujo excesso faz transbordar várias fissuras que situam-se entre estratos mais estáveis, pois seu caráter marginal a coloca na convergência de práticas que, durante toda sua história, ou melhor, suas histórias, investiram no nomadismo para além dos limites institucionais, desestabilizando o logos de uma visão de mundo, que têm no controle, na oficialidade e normatização, princípios que regulam as relações.

Sua relação íntima com o transe, com estados incomuns de consciência, com o arrebatamento em liturgias e celebrações religiosas, com o furor do entusiasmo, ou mesmo com a incompreensão ante fenômenos relacionados a desequilíbrios psíquicos e distúrbios da linguagem, de uma forma ou de outra, remontam a um aspecto desagregador e liberador de experiências humanas ligadas ao som da voz. Na realidade da Grécia antiga muitas destas práticas se ligavam a Dionísio, Eros e às Musas. Analisando textos sobre o enthousiasme ${ }^{46}$, sobretudo em Platão, Pozzo comenta sobre as elocuções confusas durante a possessão nas

\footnotetext{
45 "Eparpillées aux marges d'instituitions - ecclésiales, cliniques, scientifiques ou littéraires - garantes du sens des énoncés, elles viennent y proférer le non-sens de productions sonores que résonnent tout à la fois comme un défi et un appel à l'interprétation. Pratiques instables, fluides et intermittentes: l'histoire des glossolalies, c'est l'histoire de multiples disparitions, de soudains effacements, mais aussi de brusques effervescences, d'incessants renouveaux. Cette histoire n'a, pour l'essentiel, pas été écrite. L'entreprendre est complexe".

${ }^{46} \mathrm{O}$ entusiasmo, na Grécia antiga, referia-se à excitação e exaltação ante a manifestação divina. Era como um transe num estado incomum de consciência, fosse o indivíduo tomado por Dioniso num rito para celebrá-lo, ou mesmo numa manifestação poética como a inspiração das Musas, por exemplo.
} 
relações com o divino. Este delírio advinha do deus, como o delírio teléstico relacionado a Dioniso, a loucura de amor, dom de Eros ou ainda a loucura poética, que era o dom das musas. Observando a cultura grega, sobretudo na manifestação do entusiasmo no estado do possuído, no uso de cantos e dança para o acontecimento extático, Pozzo aponta várias características presentes nas manifestações da Nova Renovação Carismática em igrejas pentecostais contemporâneas, que explicitam um corpo que se entrega à manifestação da presença de Deus através do dom de línguas. O vocábulo glossolalia pertence principalmente ao léxico religioso e é utilizado, a princípio, no Novo Testamento, nos Atos dos Apóstolos e no 1 Coríntios, como aponta Pozzo (2013).

$\mathrm{Na}$ intermediação com o divino, que envolviam as divinações e profecias, um conjunto de elocuções estranhas e confusas pareciam confluir para uma ininteligibilidade dos discursos, como é o caso, por exemplo, da Pitonisa, feiticeira, sacerdotisa de Apolo no Oráculo de Delfos. A Pitonisa relatava o vaticínio numa linguagem estranha, num discurso muitas vezes incompreensível. Nestes contextos, a glossolalia era uma prática extática, relacionada ao transe do falante no contato indireto com a divindade. A incompreensão é uma qualidade de grande parte das mensagens oraculares, ainda que dita numa linguagem reconhecível, pois são vaticinadas geralmente em enunciados obscuros. Na própria tragédia grega, que reaviva esta tradição oracular, há sempre um sentido insondável nas prescrições das sacerdotisas dos templos, a exemplo da história de Édipo.

Voltando ao contexto cristão, a glossolalia, como o falar em línguas, alimentou momentos históricos muito diversos e Courtine (2006) os sintetiza em seu artigo apontando as primeiras glossolalias em São Paulo nos Coríntios, as primeiras xenoglossias ${ }^{47}$ em São Lucas, com a efusão do Espírito Santo, também vários episódios da tradição profética e das renovações religiosas, passando pelo Montanhismo até o século II e, posteriormente, as tradições da palavra mística nos séculos XVI e XVII com os profetas de Cévennes e de Languedoc, os Convulsionários de Saint-Mèdard no século XVII, as renovações religiosas do século XIX; ainda as glossolalias de espíritas renomadas como Hélène Smith e também o contexto asilar em que a glossolalia deixa de ser um dom divino e passa a ser sintoma patológico com suas

\footnotetext{
${ }^{47}$ Ver glossololalium.
} 
primeiras caracterizações linguísticas e psiquiátricas, tão como os neo-pentecostais que, desde a Renovação Carismática, no início dos anos 60, rezam em línguas ${ }^{48}$.

As evasões do sentido e, sobretudo dos significados, na voz, são recorrentes nas histórias das glossolalias, possibilitando vocalidades nômades difíceis de serem categorizadas por causa de seu caráter heterogêneo. Ao mesmo tempo, estas possibilidades de enunciação vêm aproximar a experiência fundadora daquele que enuncia, que é a presença de uma reverberação da matéria por meio dos ruídos que os corpos produzem sem seu necessário vínculo com os significados. Numa referência às pesquisas de Michel de Certeau (2013), Courtine discorre sobre a potência dessa experiência diante de uma voz glossolálica:

Para além do efeito do corpo de seus enunciados, elas restituem, ao preço de uma aparência, sua materialidade vocal, isto é, corporal, à língua. Ao fugir do sentido, elas encontram esta dimensão essencial da língua para um sujeito: a sensação interior, irremediavelmente singular, de que uma língua é falada, e que o corpo produz ruídos da voz. Elas lembram as teorias do signo do esquecimento daquilo em que se fundamenta sua razão: que o sujeito é falante (2006: tradução nossa) ${ }^{49}$.

Dessa forma, uma enunciação glossolálica é, antes de tudo, fazer vibrar pelo som, movimentar um corpo, tornando-o presente pela voz enquanto fenômeno da matéria, tornando a experiência uma singularidade vocal, pois um corpo que fala é um corpo que vibra e, falar e escutar-se implica esta reverberação de algo que se afirma como fenômeno fundador, que é a produção de uma centelha antiga e crucial para a consciência humana. Para Certeau, trata-se de uma ficção do dizer, pois a glossolalia não é uma língua, ela tem sua aparência, mas não sua estrutura. Para fugir das armadilhas do sentido e não se enganar com as palavras, a glossolalia é uma pura fábula, reencontro com uma fala ancestral, primeva.

Certeau (2013) faz uma provocação ao indagar se a glossolalia é um fenômeno tão excepcional assim. E vai concluir que não, pois num falar ordinário, ela se insinua com os ruídos dos corpos na articulação do dizer, em fragmentos incompreensíveis nas citações e interjeições. É como se, paralela a uma voz que organiza o sentido, entre eles o linguístico, há

\footnotetext{
${ }^{48}$ Para mais detalhes sobre estes contextos históricos ver a tese de Pozzo (2013).

49 "Au delà em effet du corpus de leurs énoncés, elles restituent, au prix d'un semblant, as matérialité vocale, c'est-à-dire corporelle, à la langue. En s'évandant du sens, elles retrouvent cette dimension essentielle de la langue pour un sujet: la sensation intérieure, irrémédiablement singulière, qu'une langue est parlée, et que le corps résonne des bruissements de la voix. Elles rappellent aux théories du signe l'oubli de ce sur quoi se fonde leur raison: que le sujet est parlant".
} 
uma voz que a corta e a duplica, eu diria até, que a multiplica. Para ele "Os ruídos paralelos que povoam as conversações ordinárias, representam uma tatuagem interlocutória e vocal sobre o discurso. Eles indicam os funcionamentos da linguagem quando ela é falada" (2013: 39 , tradução nossa) ${ }^{50}$. O nosso falar ordinário é povoado de rumores que estão "Além dos muros da língua" (ibidem, tradução nossa) ${ }^{51}$.

É esta potência de uma ficção do dizer no seio da ficção da língua que Certeau elucida no que ele chamou de utopia vocal. Na glossolalia fala-se por nada dizer, dessa forma ele coloca uma questão universal: o que é que se diz sem dizer alguma coisa? Para ele "A utopia é para o espaço social o que a glossolalia é para a comunicação oral, circunscrevendo-se em um simulacro linguístico tudo o que a voz realiza além da língua uma vez que ela a fala" (2013: 341 , tradução nossa) ${ }^{52}$, dessa forma ele aponta uma utopia vocal religiosa, como é o caso do dom de línguas, em que o não-poder-dizer (como a voz divina que é impronunciável pelos homens) passa a um poder-dizer (dom de línguas) por meio de um poder-não-dizer (o nada a dizer, intrínseco à glossolalia), isso, sustentado por uma obrigação de dizer e uma crença nesse dizer.

Por outro lado, ele fala de uma segunda utopia vocal, uma utopia poética que, diferente da religiosa, apoia-se numa ausência de obrigação, pois há uma permissão de jogar com a língua. De maneira distinta, ela se apoia na incredulidade (um senso lúdico sobre a insensatez dos significados) mais que sobre uma crença na palavra. Seria um espaço utópico ofertado à voz pela criação artística, por exemplo. As glossolalias de Artaud, como uma ficção do dizer, se apoiam sobre um falar articulado, no caso a língua francesa, e procede a uma cirurgia nessa mesma língua, de forma a experimentar as virtualidades da voz. Dessa forma, ele possibilita uma utopia vocal poética na visão de Certeau.

Existe algo na voz, uma pulsão, que não pode ser reduzida ao signo linguístico. Mas se retiramos a língua que é dita na fala, o que resta? Este é um território, cujo investimento de desejo, emana uma vocalidade glossolálica. Para Certeau "Excluindo-se todas as línguas efetivas, ele (o fenômeno da glossolalia) é o dizer de cada língua, sem o qual nenhuma língua

\footnotetext{
50 "Les bruits parallèles qui peuplent les conversations ordinaires représentent un tatouage interlocutoire et vocal sur le discours. Ils indiquent des fonctionnements du langage quand il est parlé".

51 "Hors-les-murs d'une langue".

52 "Ce que l'utopie est à l'espace social, la glossolalie l'est à la communication orale, en circonscrivant dans un simulacre linguistique tout ce que la voix réalise d'autre que la langue lorsqu'elle la parle".
} 
seria falada" (2013: 343, tradução nossa) ${ }^{53}$, isso nos conduz à reflexão do como nos colocamos a falar em qualquer língua que seja, pois "A glossolalia isola o dizer de todo dizer" $^{\prime 54}$ (idem, tradução nossa). Soa como um neutro diante da língua, algo que dá todas as condições de uma língua fazer-se passar, no entanto, não pode nunca ser essa língua. Trata-se do como nós nos colocamos no ato de dizer, configurando todos os princípios necessários para que a enunciação tenha realidade sonora e, ao mesmo tempo, ultrapassa o limite da estrutura da língua. Esta utopia vocal traz consigo as possibilidades de uma reflexão sobre uma glossolalia na arte, sobretudo, para a voz em performance, e Certeau toca neste ponto, abrindo a discussão:

Em cada glossolalia combina-se algo de pré-linguagem, relativo a uma origem silenciosa ou ao 'ataque' da palavra falada, e algo de pós-linguagem, feito de excesso, de transbordamentos ou de resíduos de língua. Assim como o mito, estas ficções juntam o antes e o depois do dizer para construir o artefato em que ele se joga (2013: 345 , tradução nossa) $)^{55}$.

Partindo destas reflexões de Certeau, Pozzo vai chamar de glossolalia lúdica, gênero distinto da glossolalia religiosa, práticas que abarcam a criação artística. O fundamento destas glossolalias seria a transgressão das normas linguísticas, efetuadas no campo da arte. Jogar e brincar com a língua constituiu um modo de operar um delírio, uma mudança de sentido, ou melhor, uma ampliação de sentidos. Como já referido antes e, recorrendo a Michel de Certeau, ela aponta um caminho para uma posterior definição dessa glossolalia:

Se a glossolalia 'ordinária' procede de um não poder dizer (Deus) a um poder (lo) dizer, uma glossolalia secundária seria o oposto disso. Apoiando-se sobre o falar articulado, ela procede a sua desconstrução por um jogo de fonemas e/ou por derrisão da palavra. Esta figura glossolálica ensaia as virtualidades da paleta vocal, fundando-se sobre uma ausência de obrigações: uma permissão de jogar a língua (Pozzo apud Certeau, 2013: 295, tradução nossa) ${ }^{56}$.

\footnotetext{
53 "En excluant toutes les langues effectives, il est le dire de chaque langue, ou ce sans quoi aucune langue n'est parlée".

54 "La glossolalie isole le dire de tout dire".

55 "En chaque glossolalie se combinent d'ailleurs quelque chose de pré-langagier, relatif à une origine silencieuse ou à "l'ataque" de la parole, et quelque chose de post-langagier, fait d'excès, de débordements ou de déchets de langue. Tout comme le mythe, ces fictions bricolent ensemble l'avant et l'après du dire pour construire l'artefact où il se joue".

56 "Si la glossolalie 'ordinaire' procède d'un non pouvoir dire (Dieu) à un pouvoir (le) dire, une glossolalie secondaire s'y oppose. S'appuyant sur le parler articulé, elle procède à sa déconstruction par un jeu sur les phonèmes et/ou par dérision de la parole. Cette figure glossolalique essaye les virtualités de la palette vocale, se fondan sur une absernce d'obligations: une permission de jouer la langue".
} 
As virtualidades da paleta vocal antecedem e podem transcender às noções linguísticas, pois existem outras linhas de acesso possíveis, fazendo algo vibrar numa zona primária de criação, e aqui não estou falando de uma perversão ou subversão dos sentidos linguísticos, que é uma outra possibilidade. Dessa forma, penso que tal glossolalia, que intenta servir a uma vocalidade para a performance, pode ir além do jogar a língua, pois pode inclusive não se apoiar nela. Tal movimento possibilita ao performador uma liberdade distinta daquela: jogar o som. Pois o princípio é procurar caminhos para vocalizar, pelo simples fato de vocalizar (que pode ser um dizer, por exemplo), não é a comunicação, mas o ato de vocalizar/enunciar que faz da glossolalia um fenômeno atômico de um corpo que se diz. Certeau fala de "jogos na fronteira" em relação ao que principia ser dito, para isso, esta zona é um "Lugar de uma abundância e de um jogo, também, porque ele não se encontra sujeito às restrições técnicas e táticas impostas pela articulação linguística da comunicação. Lugar de um indeterminado júbilo [...]" (2013: 353, tradução nossa) ${ }^{57}$. Demetrio Stratos, como pode ser visto em 'antistratosquo', levará para sua criação musical, as potencialidades do virtual no som da voz dissociado da palavra.

A poesia sonora, a música erudita contemporânea, as vanguardas europeias do início do século XX, a exemplo da poesia dadaísta, assim como a prática do grommelot $^{58}$ e as experiências de Artaud são exemplos em que a linguagem dançou ao som de um delírio poético. Jogar com a língua e/ou com o som. Jogar com a voz. A função poética da linguagem, com suas assonâncias, aliterações, onomatopeias e ritmos contribuíram para uma manifestação e expressão ilimitada de configurações possíveis para a voz em performance. $\mathrm{Na}$ música erudita do início do século $\mathrm{XX}$, a voz ganha uma importância singular em sua composição, perde-se a intensidade do texto no nível do sentido conceitual do discurso, enquanto ganha força graças à sua sonoridade incomum. É o caso de Luciano Berio com 'Visages', 'Laborintus' 2 e 'Sequenza III', e também sua colaboração com Umberto Eco no programa radiofônico intitulado 'Onomatopea del linguaggio poetico' ${ }^{59}$. A busca por elocuções extra-ordinárias, lançou criadores numa verdadeira batalha diante da linguagem. Para Pozzo

\footnotetext{
57 "Lieu d'une aisancee et d'un jeu, aussi, parce qu'il n'est pas encore soumis aux contraintes techiniques et tactique imposées par l'articulation linguistique de la comunication. Lieu d'un indéterminé jubilatoire [...]"

${ }^{58}$ Ver glossololalium.

${ }^{59}$ Estudo de uma passagem do 'Ulisses' de James Joyce com participação de Cathy Berberian.
} 
Desenvolvendo-se num meio laico, as glossolalias lúdicas tiram sua origem do mesmo obstáculo expressivo que motiva as glossolalias religiosas: a impossibilidade para a linguagem de exprimir toda a diversidade da experiência humana. A estrutura da língua não é homogênea à do pensamento. Esta distância, ao mesmo tempo que produz uma frustração inicial, também pode dar lugar a uma emissão glossolálica, admitindo sempre uma progressão em direção à possibilidade de nomear e de restituir a experiência nova (2013: 320, tradução nossa) ${ }^{60}$.

A poesia sonora do século $\mathrm{XX}$, ainda que partindo de contextos literários, foi um território fértil para a experimentação vocal. Sob a influência de pensadores da oralidade e da voz, num sentido mais amplo, como é o caso de Paul Zumthor (2010), uma noção de poesia, comumente relacionada às possibilidades linguísticas, toma o valor do som enquanto elemento da voz, dissociado das manifestações verbais. Antes mesmo de se limitar ao verbal, escrito ou falado, a poesia era encarada como som em sua manifestação vocal. Demais, uma noção de inacabado de emanações dadaístas, fizeram a voz encarar o acaso como via de criação para suscitar novas sonoridades. Frederico Fernandes, no prefácio do livro de entrevistas de Enzo Minarelli, sintetiza este momento crucial da poesia sonora, que poderia ser entendido como potenciais elocuções glossolálicas:

O ambiente performático, de bases assentadas na oralização (como a enunciação de palavras) e nas vocalizações (uso de diferentes sonoridades, explorando sobretudo os potenciais vocálicos), era propício à casualidade, pois permitiria o acontecimento de expressões e de manifestações de linguagens potencialmente significativas, que ignoram a lógica e a razão da língua, não ajustadas à escrita (2014: 16).

As relações entre música e voz, cujas pesquisas sonoras se debruçaram sobre as raízes poéticas da linguagem, levaram as vocalidades no contexto da performance a uma multiplicidade singular ao evidenciar as experimentações de um 'fora' da própria linguagem.

Além das realidades artísticas e mítico-religiosas, a glossolalia também se infiltrou nos entres de instituições psiquiátricas e seus saberes, sobretudo em suas relações com a linguística. A psiquiatria, em seus registros nosográficos, compendiou, ao longo de sua história, vários distúrbios psíquicos relacionados à voz, acompanhados de descrições sobre discursos

\footnotetext{
60 "Tout en se déployant dans un milieu lä̈c, les glossolalies ludiques tirent leur origine du même obstacle expressif qui motive les glossolalies religieuses: l'impossibilité pour la langue d'exprimer toute la diversité de l'expérience humaine. La structure du langage n'est pas homogène à celle de la pensée. Cet écart, tout em produisant une frustration initiale pouvant donner lieu à une émission glossolalique, admet toujours une progression vers la possibilité de nommer et de restituer l'expérience nouvelle".
} 
incoerentes, muitas vezes relacionados a distúrbios da linguagem. A busca pela compreensão de discursos relacionados à glossolalia, fez-se presente em todos os contextos de suas manifestações. Isso levou à uma grande produção de textos que intentava desvelar seus supostos significados e sentidos.

Os aspectos insensatos de tais vocalidades fizeram pressupor que algo pudesse ser decifrado, e a linguística, a psiquiatria e a psicanálise não cessaram as buscas por significados e interpretações, procurando descrever processos psíquicos desarrazoados e buscando sempre uma organização de sentido por trás de uma série de sons vocais. Certeau (2013) pondera, por exemplo, as investigações de Oskar Pfister, amigo de Freud, em relação ao método psicanalítico da Associação de Ideias. O método, segundo Certeau, consistia em dissecar o discurso incoerente em unidades fonéticas, oferecendo uma fórmula interpretativa que levava à tradução escrita da voz num discurso fanático. No entanto, estas vozes insensatas seriam assumidas apenas como máscaras e Certeau vai criticar justamente o simulacro no qual caía esta "moralidade hermenêutica" e a forma como "As astúcias da razão lutam contra essas vozes para emudecê-las em uma decoração determinada pelo trabalho que se opera nos bastidores" (2013: 348, tradução nossa) ${ }^{61}$. Na verdade, a despeito dos postulados próprios da exegese psicanalítica, a glossolalia tem suas próprias razões e sua singularidade enquanto prática. Ao mesmo tempo, Certeau vai questionar se, ao instituir um sentido para o que não parecia ter sentido algum, esta forma de análise não estaria duplicando, ou mesmo se contradizendo, ao criar uma outra ficção do dizer:

Assim, somos levados a perguntar se o conteúdo não tem por função esconder o engano da comunicação e se, reciprocamente, a percepção de um engano camuflado pela organização do sentido não seria a responsável pela utopia vocal que, destruindo a possibilidade de articular o sentido, tenta restaurar um falar (2013: 349, tradução nossa) ${ }^{62}$.

Um verdadeiro imbróglio do quiproquó. Ao mesmo tempo, a busca por um significado ou mesmo por um sentido particular, denota uma angústia diante daquilo que parece fugir a todas as normas, e à própria possibilidade de que se instaure o caos, a exemplo do enigma da

\footnotetext{
61 "Les ruses de la raison luttent contre ces voix pour les muer en un décor déterminé par le "travail" qui s'opère dans les coulisses".

62 "Par lá, on est amené à se demander si le contenu n'a pas pour fonction de cacher la tromperie de la communication et si, réciproquement, la perception d'une tromperie camouflée par l'organisation du sens ne serait pas à l'origine de l'utopie vocale que, en détruisant la possibilité d'articuler du sens, tente de restaurer un parler".
} 
Esfinge, para o qual, o 'Decifra-me ou devoro-te' é uma insinuação da falta de sentido que pode consumir a vida de uma pessoa. No mesmo sentido, a necessidade de um dom de interpretação de línguas ao lado do falar em línguas, ou mesmo dos vaticínios oraculares que necessitavam ser decifrados, ou ainda Joyce, cujo 'Finnegans Wake', resiste até hoje aos limites, ou ainda à falta de limites, da interpretação.

A linguística, em busca de sua autonomia, também desenvolveu métodos na busca por sentidos implícitos em enunciações glossolálicas. A parceria de Ferdinand de Saussure, linguista suíço, e do médico e professor Théodore Flournoy, ficou conhecida pelo caso da médium Hèlene Smith ${ }^{63}$, que falando numa língua desconhecida, dizia lembrar de suas vidas passadas. A língua falada pela médium foi chamada de 'marciano' e, nas análises de Saussure, parecia-se com o sânscrito em junção com outras línguas. Comentando este caso, Certeau (2013: 349-351) diz que nas análises de Saussure, Hélène, ao lado de uma vontade de um dizer outro, se identificava com uma língua conhecida, no caso o sânscrito, e que sua linguagem ininteligível (charabia), visava não uma língua, mas algo como a instituição de um falar.

De qualquer forma, houve uma grande confusão sobre a glossolalia religiosa e o psitacismo ${ }^{64}$ evidenciado pelos médicos. Seja no contexto mítico-religioso, seja no contexto psiquiátrico, esta manifestação aponta para o inexplicável, para um desconhecido que fere toda e qualquer norma, seja litúrgica, seja dos padrões para se viver em sociedade. Florance de Merèdieu, biógrafa de Artaud, comenta as investigações glossolálicas dele enquanto esteve internado:

As cantilenas, os rituais e encantamentos fazem parte, desde o período de internação, desse pequeno teatro pessoal que Artaud construiu para si pouco a pouco, teatro afetivo, e muito físico, que lhe serve de proteção contra o mundo exterior. A oralidade tem, no seio desse dispositivo defensivo, papel primordial. Artaud canta, cantarola, uiva e salmodia estranhas canções. A origem dessas glossolalias é múltipla. Elas se enraízam, como vimos, na fascinação de Artaud por certas melopeias selvagens (como as dos índios mexicanos descobertas em Paris dos anos de 1930). Mas elas remetem também aos cantos religiosos de infância e (e de modo fantasmático e mítico) aos primeiros cantos da Igreja Cristã. As glossolalias são, enfim, o que ousaríamos chamar "um gênero psiquiátrico", os médicos designando desse modo essas sílabas ou essa linguagem inventada, tão frequente entre os loucos. E Artaud, o louco e internado, no decorrer dos anos, passou a dominar perfeitamente as glossolalias (2011: 907).

\footnotetext{
${ }^{63}$ Este caso foi fartamente detalhado e parte das investigações foram comentadas por Pozzo (2013).

${ }^{64}$ Ver glossololalium.
} 
Mèredieu aponta um caráter psiquiátrico às glossolalias surgidas no contexto clínico, ela fala de "proteção contra o mundo exterior", "dispositivo defensivo" ou ainda "gênero psiquiátrico", estes termos colaboram com uma visão mais restrita sobre esta produção de Artaud, minimizando a potência com que a obra desse período tem impactado sobre produções contemporâneas como na filosofia e nas artes. Demais, ela reitera o caráter heterogêneo e amplo de tais elocuções. De qualquer forma, havia uma confluência de fatores que evidenciavam o caráter fronteiriço de suas criações: elocuções de um louco ou uma prática lúcida da crueldade? E, retomando a crítica de Derrida aqui comentada, por que uma ou outra coisa?

A ênfase da psiquiatria, que enquadrava as glossolalias em categorias nosográficas, recaía sobre a ininteligibilidade do discurso, relegando o fenômeno a uma estruturação simbólica do delírio e à regressão da linguagem. Relacionava-se assim, esta linguagem, ao balbucio da criança, ainda sem um léxico e uma lógica formal na construção de seu pensamento, ou ao grunhido animal, um nível anterior de desenvolvimento psicossomático, ou ainda qualquer noção de proto-linguagem considerada como um discurso menor. Ou seja, a nosografia descrevia os distúrbios em que as falas e os sons não partilhavam de uma atitude convencional na construção da linguagem, cuja a aleatoriedade, rompia com a ordem lógica do mundo.

Em muitos contextos de uma glossolalia que se desenvolveu no meio artístico, como é o caso dos movimentos surrealista e dadaísta e de Luciano Berio e Demetrio Stratos na música, o retorno a uma fase anterior da linguagem, como a sonoridade que se poderia imaginar no início do falar humano nas utopias da linguagem original, mesmo o falar das crianças anterior à articulação da língua, foram recursos utilizados por artistas que se valiam de motivos onomatopeicos e rítmicos, aliterações e outros recursos da linguagem para a investigação de uma sonoridade esquecida.

A necessidade de se compreender o sentido dessas elocuções aparentemente sem sentido, levou a aproximação da glossolalia a uma linguagem, o que possibilitaria sua escrita e, posteriormente, sua tradução para a compreensão do discurso incoerente. A ênfase no significado e na interpretação, de certa forma, fez com que aspectos de uma materialidade sonora ficassem encobertos pelo juízo de um logos condutor do sentido. Na glossolalia, a experiência da vocalização faz com que o som tenha valor intrínseco como acontecimento de 
um corpo ruidoso, como princípio básico da matéria que vibra e faz vibrar. Dessa forma, o simulacro de uma suposta língua no enunciado glossolálico, na prática, não se confunde com uma língua efetiva, o que implica dizer que as sonoridades de uma glossolalia é tudo aquilo que excede ou que resta dessa mesma língua.

Deleuze e Guattari em 'Postulados da Linguística' vão dizer que toda a linguagem é discurso indireto, sobretudo discurso indireto livre: "Existem muitas paixões em uma paixão, e todos os tipos de voz em uma voz, todo um rumor, glossolalia: isto porque todo discurso é indireto, e a translação própria à linguagem é a do discurso indireto" (2002:13), assim, todos os ruídos e tudo aquilo que rumora para um aquém ou um além da linguagem, estaria numa virtualidade glossolálica. Algo marulha na vocalidade, pois a glossolalia ultrapassa a voz do indivíduo, ela é uma coletividade, é polifônica. Esta virtualidade é o que coloca a língua em estado de experimentação ou, como eles chamam, variação contínua, em operações de a-significância e dessubjetivação, visto que programa inverso a este será feito pelo discurso direto.

Apoiando-se nas ideias de Austin, para quem a linguagem é ação, pois para além de sua interioridade sígnica, ela se relaciona com sua exterioridade que é factual, ou seja, a linguagem cria realidades, agindo sobre o mundo das coisas e não podendo ser separada dessas transformações, Deleuze e Guattari vão propor uma pragmática para a construção de sentidos de enunciações, baseada nos pressupostos implícitos ou não-discursivos dessa linguagem. A pragmática vai abraçar a diversidade, a expressão, a manifestação dos dizeres, numa relação com o mundo, com a vida. Estas considerações são pertinentes, visto que muitos discursos glossolálicos se valeram de conflitos com a língua, na exploração de limites entre essa língua e a fala, entre a escrita e a fala e entre esses territórios e a voz. Numa análise pragmática, muitas das transgressões e subversões linguísticas a favor de processos glossolálicos funcionam como nomadismos dentro de uma linguagem mais vasta que a dos marcadores sintáticos, semânticos ou fonológicos, ou seja, "A expressão atípica constitui um extremo de desterritorialização da língua, representa um tensor, isto é, faz com que a língua tenda em direção a um limite de seus elementos, formas ou noções, em direção a um aquém ou a um além da língua. (Deleuze; Guattari, 2002: 44). Faz-nos lembrar o embate de Artaud com a língua francesa, ao que Sontag sentencia: "Na feroz batalha de Artaud para transcender o corpo, tudo é eventualmente transformado em corpo. Em sua feroz batalha para transcender a linguagem, tudo é eventualmente transformado em linguagem" (1986: 50). 
A glossolalia altera e perturba um território, inquietando princípios identitários e promovendo linhas de fuga, fazendo agenciar um conjunto heterogêneo de regimes de signos. Antes mesmo de dizer o que é ou o que não é glossolalia num contexto para a voz em performance, voltemos a uma das acepções para a origem de glossa: trata-se de um termo que, intencionalmente utilizado desestabiliza a banalidade de um discurso. Demais, ante a impossibilidade da língua para expressar toda diversidade da experiência humana, não raro, ela é criada dentro de uma noção de variação contínua de aspectos linguísticos e, avançando um pouco mais, teria relação com o jogar o som da voz, se apossando de todos os excessos para um aquém ou além de programas vocais estáveis. A glossolalia, como prática marginal, tem uma relação com tudo aquilo que fere determinadas normas, apontando para uma incompreensão de significados e, muitas vezes, até mesmo de um sentido imediato. Também se relaciona com uma experiência fundadora da produção do som por meio do corpo, ou seja, enquanto vocalizo, reverbero e faço a matéria ressoar-me.

Se por um lado, a psiquiatria e a linguística investiram energia no sentido de decifrar e normatizar, de alguma forma, processos intensos de uma vocalidade irrefreável, a glossolalia, como uma vertente excessiva para além do significado, não pôde ser contida e deixa aberto um campo infindo de lacunas relacionadas ao espectro vocal. De qualquer forma, a glossolalia, enquanto um conjunto de práticas para a voz em performance, não exclui de si a palavra, seja escrita ou falada, ou mesmo o logos na construção de mundo. Ela não é uma polarização do discurso, mas está entre todos os discursos possíveis, sempre em algum tipo de processo fronteiriço.

Se consideramos a glossolalia como um limite ao qual não se chega nunca, pois trata-se de um devir da experiência vocal, poderemos vislumbrar as possibilidades contínuas de um pacto com o diabo. Uma singularidade que pactua. Entre isto e aquilo, suas práticas se valem de segmentos e estratos para o delírio da voz. 


\section{a rangmbde a rangmbde a rouarghambde}

O que aconteceu com Artaud para que um jorro glossolálico acontecesse? É fato que não foi um acontecimento pontual e circunstancial, mas de um longo processo de investimento de desejo. Não é por acaso que sua entrega a uma operação sobre a linguagem, que possibilitou as sílabas inventadas e os cantos estranhos marcados ritmicamente, se deu com maior intensidade no fim de sua vida. Há muitas fissuras e zona indiscerníveis nessa experiência atravessada por uma multiplicidade de temas cujo peso faz borrar ainda mais as fronteiras. Portanto, há sobretudo sugestão poética, vislumbres e possibilidades abertas de investigação e compreensão. Em Artaud, a prática da escrita e do desenho tornaram-se campos em que toda uma convulsão político-espiritual transbordava excessivamente. A arte de embaçar os discursos e de tornar híbridos os territórios.

Nem tudo o que Artaud escreveu neste período foi publicado e, algumas publicações póstumas parecem ter sofrido intervenções arbitrárias por parte do editor, a exemplo da edição de 'Histoire vécue d'Artaud-Mômo' (2009), publicada pela editora Fata Morgana, que traz uma nota de Serge Malausséna explicando a incompatibilidade da publicação com os originais, inclusive o título. Pode-se inferir o quão pouco palatável deve ser boa parte dos textos desse período, o que aponta para uma desmedida desses escritos em relação aos meios de publicação.

Foi a compulsão e o frenesi pela escrita e pelos desenhos que o levou à prática oral na invenção de palavras glossolálicas. Mèredieu fala de suas liturgias pessoais nestes contextos:

As glossolalias multiplicam-se na medida em que sua escrita torna-se mais elétrica, rítmica e musical. No final da vida de Artaud, elas são parte integrante dos rituais que ele estabeleceu para lutar contra seus demônios e constituem uma peça maior desse Teatro da Crueldade que ele não cessa, então, de praticar. São sílabas feitas para serem faladas, escandidas, ritmadas, cantadas, ululadas. E Artaud dedica-se a essa prática em Ivry, batucando em seu cepo de madeira, a uma velocidade que poderia se tornar frenética (2011: 908).

O ritmo, a musicalidade e a intensidade da escrita fê-lo transpor o limite da língua para também exercê-lo na voz. Imaginar Artaud numa prática excessiva da escrita que alimenta a vocalidade em performance que retroalimenta a escrita num ciclo constante de horas, dias, 
meses a fio, é imaginar uma figura que procura transcender os limites nos quais opera a palavra para fazê-la delirar numa operação vocal. Uma pitonisa delirando num quarto de asilo? Uma meditação cruel buscando uma alternativa ao desespero? Uma voz patológica procurando grasnar os sentidos de uma neurose? Um poeta do som procurando transmutar e expandir os limites de suas indagações sobre a arte e sobre a vida? Uma voz molecular, sanguínea, experimentada no furor de uma entrega, exercício rigoroso, prática afetiva, glossolalia, vinho sonoro.

Grande parte dos últimos escritos de Artaud foram redigidos segundo uma técnica de improvisação oral a partir de fragmentos escritos, que ele praticava no fim de sua vida, como aponta Évelyne Groosman numa nota apresentada em 'Interjections', parte de 'Suppôts et Suppliciations' na publicação de Oeuvres (2005). Na leitura do texto, percebe-se que ela está se referindo, sobretudo, às glossolalias, que eram ditadas à uma datilógrafa à sua disposição: maloussi toumi / tapapouts hermafrot / emajouts pamafrot / toupi pissarot / rapajouts erkampfti [...] lokalu durgarane / lokarane alenin tapenim / anempfti / dur geluze / re geluze / tagure / rigolure tsipi (Artaud, 2004: 1335). Demais, essas glossolalias eram praticadas, escandidas e supliciadas nos quartos dos asilos onde ele esteve internado. Seus textos além de suscitar todo um espectro do som, eram verdadeiros registros de uma voz experimentada.

$\mathrm{Na}$ reinvenção de uma 'nova língua', Artaud usa o que Dumoulié chamou de recurso do idiotismo "termo que designa um uso absolutamente pessoal da língua, mas que também pode ser compreendido como a expressão de uma santa idiotice" $\left(2003: 107\right.$, tradução nossa) ${ }^{65}$, o que Deleuze chamou de a capacidade de gaguejar na sua própria língua. Interessante notar que quando Artaud diz que vai escrever para analfabetos e iletrados, ele não tem a 'intenção de' escrever para um leitor, como avalia Deleuze ${ }^{66}$, mas antes de mais nada, ele se coloca 'em lugar de', no lugar dos iletrados, no lugar dos idiotas, o que corrobora com uma prática de dessubjetivação em que o 'eu' é atravessado por uma coletividade, pois não se trata do 'Eu' que responde aos assuntos privados. Assim opera o discurso indireto como fluxo de uma glossolalia, pois "Escrever é talvez trazer à luz esse agenciamento do inconsciente, selecionar as vozes sussurrantes, convocar as tribos e os idiomas secretos, de onde extraio algo que denomino Eu [Moi]" (Deleuze e Guattari, 2002: 24).

\footnotetext{
65 "[...] terme qui désigne un usage absolument personnel de la langue, mais dans lequel il faut aussi entendre l'expression de la sainte idiotie".

${ }^{66}$ L'abécédaire de Gilles Deleuze (A de Animal) - https://www.youtube.com/watch?v=MxqnjjFpMXU.
} 
Ainda diante da experiência de um corpo no embate com a língua, para quem Artaud vai procurar tornar-se um gago de nascença, recorrer à glossolalia é "[...] a exigência da ficção necessária para representar uma experiência inefável e incomunicável" (Certeau apud Dumouliè, 2003: 109, tradução nossa) ${ }^{67}$. Esta experiência vai fazer agenciar um conjunto de elementos peculiares na vida de Artaud: a ideia da encarnação do Verbo, as práticas cabalísticas, a linguagem dos idiotas, que tem relação com certa pureza e genuinidade de uma linguagem primeira, balbuciante, bruta. Tudo isso denota um desconforto com todos os juízos de deus, expressos no poder das instituições, nas linguagens instituídas e na articulação do corpo.

Em seu ensaio 'Enlouquecer o Subjétil' (1998), Derrida vai falar da força exercida sobre os suportes na criação de Artaud, sobretudo da violência sofrida e imposta por ele à língua. Nos processos de cirurgia, dramaturgia e incubação uma pergunta se faz ouvir: o que é o subjétil? Pergunta inglória se buscarmos um fim que a abarque e situe suas fronteiras, mas muito digna existencialmente se nos entregarmos às investigações do ato criativo. A palavra que é referida por Artaud por três vezes ao longo de sua vida, a princípio parece um neologismo, mas já era usada na Renascença referindo-se ao suporte sobre o qual vertia a criação do artista plástico, seja o mármore, o papel, a tela, a madeira. Em Derrida ela ganhará a amplitude de um conceito em aberto, que se nega à definição, a um fim, a uma forma, pois parece supor toda e qualquer forma. $\mathrm{O}$ contexto desta manobra conceitual vai tratar da imersão de Artaud em seus processos de criação. A imersão é sempre um limite, está sempre inacabada, a cada passo percebe-se que se pode ir mais fundo, ou mais fora, ou mais apenas, pois o subjétil é desgarrado, não responde nada, e responde tanto.

Artaud, atado ao princípio rigoroso da crueldade, procurando um caminho alternativo ao dos órgãos, operando com extrema violência na linguagem, tateia as fronteiras da língua, das artes, de si, sobretudo. É neste contexto de luta e investigação, regado a entorpecentes e uma sede infinda de berrar ao mundo, que as glossolalias são alquimiadas. O subjétil faz vibrar um campo de criação intenso em que uma multiplicidade de camadas o abarcam, pois trata-se de uma potência virtual em que vários aspectos da criação artística podem se dar. O que é o subjétil é também o que se é em criação, o que é criado, os suportes desta criação e todo o processo que envolve o embate para que conteúdos nasçam e se multipliquem na carne da

\footnotetext{
67 "[...] l'exigence de la ficiton nécessaire pour représenter une expérience ineffable et incommunicable".
} 
existência, seja em escritos, desenhos, gritos, pensamentos, pois é uma vida que se transforma e faz devir algo. Que algo é esse? O que está encubado, diria Derrida, pois o subjétil é incubado, é maturado, sofre processos intensos de dramaturgia, cirurgias. Ele também está deitado embaixo, é suporte estável, que jaz, é também superfície e, matéria, “...organiza o corpo-a-corpo com Artaud [...] um corpo-a-corpo com a questão da língua" (Derrida, 1998: 29).

"Um subjétil não é um sujeito, muito menos o subjetivo, não é tampouco o objeto, mas exatamente o quê, e a questão do 'quê' guarda um sentido no que concerne ao que está entre isto ou aquilo, o que quer que seja?" (ibidem, p. 38, grifo do autor). A questão do entre é aqui uma poética das aberturas, sobretudo, como lança Derrida, a de como dirigir-se a um corpo estranho: entre o criador e o que é lançado, arremessado enquanto obra, entre uma linguagem e outra, entre uma camada e outra, entre um limite e outro. O subjétil parece irrepresentável, intraduzível, inapreensível, ele pode até estabilizar-se sob um ou outro aspecto, mas foge quando quer.

Derrida faz notar que tal conceito nasce de uma relação entre uma pictografia, um desenho, e sua relação com o suporte, com a escrita e com o criador, justamente por, não sendo palavra, 'falar mais'. Dessa forma, tal desenho em Artaud, que é uma forma possível do subjétil, é algo que deve ser escutado sobretudo, pois foi engendrado num esforçar-se pra dizer aquilo que não pode ser dito nem escrito, já que povoa um território em transição, uma zona indiscernível. Nesse 'escutar' o subjétil prolifera-se, também, uma glossolalia que procura livrar-se da língua, como se a pictografia fosse forjada boca afora:

Desenhar com a boca não é somente dar-lhe voz, sopro e língua antes das palavras, é atacar o suporte com esses instrumentos sólidos, incisivos ou trituradores que são os dentes, é comer, por vezes mastigar o subjétil, a "coisa", se se pudesse dizer, tanto quanto seu corpo glossemático ou seu fonograma; a "palavra" "subjétil" é assim desenhada além de seu senso consignado, normatizado, racional. É imediatamente enlouquecida (Derrida, 1998: 52, grifo do autor).

O subjétil é, além de uma potência sonora que busca ser escutada, uma zona de operações cirúrgicas e violentas. É aquilo que precisa de um delírio e de uma força singular para poder fazer gaguejar a linguagem. Dessa forma, ele é também o movimento que se alastra com o processo da criação, aquilo que é lançado enquanto criação, que também atravessa o suporte. 
O próprio criador, que também é lançado, atravessado na convulsão criativa. As palavras que são lançadas sobre o papel, as algaravias que se processam no ar e na matéria, o artista enquanto lance da criação, ou seja, para Derrida ele pode se tornar tudo.

Tudo o quê? A glossolalia em Artaud, por exemplo, investe desejo sobre diversos estratos: um vocal, um linguístico, um do corpo articulado, um teológico... O desejo, que é o próprio devir, busca linhas de experimentação, busca pactuar para investir-se no ato criativo, numa investigação que é uma investigação de si, trata-se de uma transgressão de limites pessoais também, pois a glossolalia procura exceder, transbordar um suporte, uma regra, uma possibilidade de ação. Também procura dar passagem às vozes dos outros. O devir da voz aqui tratado abarca os suportes, os estratos, a língua o criador, pois ele "É um lugar de incubação. Toma sobre si todas as formas, se supõe ou pressupõe e se subtrai portanto a todas as oposições...” (Derrida, 1998: 108) e ainda “...o próprio etcétera como lugar de incubação universal, a preocupação absoluta, o que traz tudo em gestação, gera tudo e pare tudo, capaz de tudo" (ibidem: 102). A incubação de gritos, de uma fórmula litúrgica concentrada num conjunto de sons, a incubação de sonoridades subreptícias, de sílabas inventadas, de uma voz a ser, inter reinos, entre si, territórios de embates. Combates-entre como disse Deleuze, pois "A guerra acontece entre vários debaixos" (ibidem: 86).

E o que é o debaixo? O abismal de si? Onde se lança e é lançado o que se cria em busca de outras camadas vocais, camadas sonoras, camadas de si, também o que é bloqueado e o que é permitido passar, assim como o que é retido, ainda que seja um léxico embrenhado na garganta, intervindo na molecularidade, empatando a foda, dando materialidade à crise. Pois no vacilo do 'eu', algo busca os dentros e os foras, é uma integridade atômica que busca, sofre e faz transbordar: “...a matéria, subjétil de todas as palavras, aí simboliza bem o lugar vazio do tormento e da mutilação" (ibidem: 102) e, como aquele que vive a criação "atormenta em si a matéria para dela fazer saírem seres" (idem).

Se perguntarmos qual o suporte para uma voz glossolálica, o 'si', inter reino perpassado por uma coletividade, seria uma dimensão pontual para um devir de possíveis respostas. O si de Artaud singularizou suas glossolalias. Dessa forma, criar um corpo sem órgãos para uma vocalidade em glossolalia não teria ressonância com o trânsito do desejo entre as camadas de subjétil? O conjunto de práticas não faria ressoar com as operações cirúrgicas sobre os suportes ou os estratos? A incubação não ressoa com o desejo, com as formas que este desejo 
pode tomar? Talvez uma coisa não seja necessariamente a outra. Mas será que não se forma aí uma zona de indiscernibilidade? Pois "um conceito possui um devir que concerne [...] a sua relação com conceitos situados no mesmo plano" (Deleuze, 2004: 30), ou seja, ele é uma ordenação de seus componentes por zona de vizinhança. Conexão, zona, ponte, heterogênese, poética dos entres, micropolítica de vizinhança...

Artaud buscava a apropriação do direito de criar seu próprio corpo, sua própria língua, sua própria voz, sua própria vida enfim. Direito este expropriado pela figura divina. O juízo de deus, dessa forma, tornava o seu dizer uma sombra menor do infinito verbo divino. Adrian Morfee em seu livro 'Antonin Artaud's Writing Bodies' (2005) comenta o embate de Artaud na busca por uma voz própria não minimizada pela voz do criador. Para ele, o livrar-se da linguagem, que também tinha o sentido de possuí-la e não necessariamente liberá-la, significava tornar-se demiurgo de suas próprias criações. Dessa forma, a glossolalia parecia não ter uma relação subalterna ao verbo de deus, soava antes como um anti-verbo, uma evasão voluntária do julgamento divino. Morfee comenta um episódio cujos princípios flertam com o enlouquecimento da linguagem em Artaud e com a ideia de excesso na glossolalia. Sabe-se que Artaud manteve uma relação de amor e ódio com o médico-diretor em Rodez, o Dr. Fèrdiere e que tal ligação tinha também um vínculo intelectual. Durante algum tempo de seu período de internação, Artaud dedicou-se à tradução de textos, em sua maioria, de língua inglesa. A pedido de Fèrdiere, Artaud traduz o Jabberwocky ${ }^{68}$ de Lewis Carrol. Transcendendo ao trabalho de tradução e negando-se usar até mesmo o francês moderno, Artaud cria um verso extra, impronunciável, como um excesso do discurso: $a$ rangmbde a rangmbde a rouarghambde. Ao mesmo tempo em que uma intrusão descabida parece se revelar, um transbordamento escoa dali, sem amarras ou ortodoxia, a persistência da loucura no excesso. De acordo com Morfee,

Para Artaud o apelo da glossolalia reside no fato de ela ser essencialmente performativa com reivindicações explícitas para atuar diretamente na realidade, algo que Artaud deseja claramente: 'toda Poesia Real' é dita para se chegar 'aos Atos de Verdadeira Magia'. A palavra é para transcender o espaço da escrita, e o poder gerador da glossolalia torna não apenas mágica, mas assim, um desafio para a Palavra de Deus. A Palavra divina é linguagem que cria e a glossolalia de Artaud, assumindo aspirações

\footnotetext{
${ }^{68}$ Poema com linguagem nonsense e experimental que compõe o livro 'Through the looking-glass, and What Alice Found There' (1871). Ficou muito conhecido por sua tradução para diversas línguas e pela dificuldade de tal tarefa. Há uma versão em português feita por Augusto de Campos intitulada 'Jaguadarte'.
} 
geradoras semelhantes, tanto emula quanto rivaliza com ela (2005:109, tradução nossa) ${ }^{69}$.

É neste sentido que Morfee aponta a engenhosidade de Artaud enquanto aquele que recobra do Verbo Divino o que é seu de nascença e de vida: a liberdade de dizer-se a si mesmo e de que sua voz tem sentido em si mesma. Trata-se de uma luta contra o pretenso poder infinito de Deus, pois esta ideia de infinito na voz do Criador, relega a sua voz a um aspecto diminuto, já expropriado no ato da fala. É como se ele dissesse em seu embate teológico: Eu crio enquanto digo e minha voz possibilita universos genuínos, pois ela é criação a priori, é matéria minha, é emanação do meu corpo, não uma reprodução de uma fonte legítima determinada, pois eu sou a fonte. E um corpo sem órgãos foi engendrado. Não seria esta uma resposta a uma glossolalia religiosa? Uma glossolalia enquanto utopia vocal apontada por Certeau e definida por Pozzo como uma glossolalia lúdica?

Ao mesmo tempo, Dumoulié reforça a importância da entrega de Artaud ao ato de traduzir apontando um devir-tradução na busca por uma língua universal:

Fazer do verbo do outro seu próprio corpo e perder a palavra ao estrangeiro são traços da busca mística de uma "língua transversal". No asilo de Rodez, na busca de um corpo a ser refeito, de uma língua a ser reinventada, de uma identidade paradoxalmente a ser reencontrada, Artaud toma o caminho de travessia da tradução (2003: 107, tradução nossa) ${ }^{70}$.

A língua das línguas forjada por Artaud buscava uma reinvenção e uma submissão do francês ao furor de uma operação do excesso, que Certeau chamou de "opacificação do signo" (Certeau apud Dumoulié, 2003: 108, tradução nossa) ${ }^{71}$, buscando devolver à palavra uma materialidade sonora. Dessa forma, a tradução era um campo fecundo para o despojamento do som, do reencontro de uma matéria delirada enquanto vibração.

\footnotetext{
69 "For Artaud the appeal of glossolalia lies in its being essentially performative with implicit claims to act directly on reality, something Artaud clearly wishes: 'toute Poésie Réelle' is said to amount to 'des Actes de Magie Vraie'. The word is to transcend the space of writing, and the generative power of glossolalia makes it not just magical but thereby a challenge to the Word of God. The Divine Word is languague that creates, and Artaud's glossolalia, by assuming similar generative aspirations, both emulates and rivals it".

70 "Faire du verbe de l'autre son propre corps, perdre la parole à l'étranger sont autant de traits de la recherche mystique d'une langue traversière. À l'asile de Rodez, en quête d'un corps à refaire, d'une langue à réinventer, d'une identité paradoxale à retrouver, Artaud emprunte la voie de traverse de la traduction".

71 "opacification du signe"
} 
Avancemos um pouco em relação à singularidade das glossolalias de Artaud, sobretudo na sua relação com a língua francesa e sua cirurgia efetuada na camada linguística. Uma língua, seus códigos gramaticais, seu léxico e todas as normas que pressupõem sua organização, guarda em si uma camada política enquanto efetuação de corpos sociais, enquanto conveniências oficiais, para demarcar também limites da comunicação e da coerção do desejo. As noções de sujeito, objeto, predicado, a ênfase num verbo ou num adjetivo, a substantivação do discurso, por exemplo, tornam peculiar os povos e os indivíduos a partir de suas línguas e dialetos. Para Derrida a própria língua francesa, como estrato, suporte e campo de investigações sonoras na sua relação com a voz servia, para Artaud, como um subjétil passível de enlouquecimento:

\begin{abstract}
Artaud faz com o francês o que faz com o subjétil. Ataca-o, faz-lhe uma cena, opera-o, maltrata-o para seduzi-lo etc. Tudo o que dissermos doravante de "subjétil", o leitor poderá logo traduzir para o "francês", para a "língua francesa" dita materna. Mas para escrever contra, tudo contra sua língua materna - o que melhor se lhe pode fazer - deve-se sair de novo dela, descansar nela, tomá-la como alvo, sair dela também para a partida e a separação (1998: 133).
\end{abstract}

Derrida refere-se à operação cirúrgica de Artaud sobre a linguagem e desenhos como trabalho da "mão do homem", o que denota um devir como demiurgo de si, como já comentado antes. Para tal, ele faz uma imersão nos sentidos dos verbos usados para o enlouquecimento do subjétil: sondar, talhar, raspar, limar, coser, descoser, esfarrapar e costurar. Estas operações são atos de incubação e gestação. É o que se opera sob os debaixos dos debaixos.

Um suporte como a língua cabe a glossolalia? Consegue ela vibrar todo o espectro sonoro, anímico-espiritual, conceitual e político desta manifestação? A língua tolera, aguenta, sofre até um limite? Que limite é este? Quando ela não mais atura, não mais pode sofrer, não mais tolera, isto é o insuportável. Na agonia vocal de Artaud, um corpo denso de desejo faz um limite entrar em delírio. Mas, enlouquecer a linguagem é possibilitar toda a glossolalia possível? Existe todo o possível desta vocalidade? Não seria a voz um outro suporte? O que suporta a voz? Subjetilizar a voz? Suporte. Subjétil. Insuportável. Limite. Língua. Voz.

Como já foi dito, boa parte dos últimos textos de Artaud era ditada, de forma que a sonoridade muitas vezes fazia o texto se modificar a exemplo de 'Interjections' e 'Fragmentations', partes de 'Suppôts et Suppliciations' (2005) e, na verdade, tudo aquilo que ele produziu nesta época 
pode ser visto sob um espectro sonoro, e ainda sob a necessidade de uma encarnação e de uma materialização. Seus textos almejavam uma animação, como se, ganhando vida e corpo próprio, buscassem atravessar os suportes, as linguagens, supliciando ao menos um sopro de voz. A linguagem para Artaud, dizia Derrida, "Deveria exprimir-se ela mesma sem demora, sem etapas, sem atraso. No corpo-a-corpo em que um sopro se lança contra o subjétil, ele se faz literal e material" (1998: 93, grifo do autor), pois a angústia de Artaud era real em relação à língua, e o sentido de uma crueldade o colocava constantemente em vias de uma exigência desesperada de operar o texto e toda convenção linguística e, a despeito de ter escrito tanto e convulsivamente, ainda sim, o jorro de um grito, que muitas vezes não conseguia ser gritado, o assolava enquanto necessidade de uma voz tresloucada. Comentando parte do poema 'Cogne et Foutre' de 'Interjections', Derrida toca novamente no tema da necessidade de uma real idiotia diante do estrato da escrita:

[...] exibe o requisitório contra a "letra escrita", isto é, a letra inscrita na palavra, submetida à proposição discursiva e a suas normas lógicogramaticais: "As palavras que usamos me foram passadas e as emprego, mas não para me fazer compreender [...] exatamente não as emprego, / na realidade não faço outra coisa senão me calar [...] eu não emprego palavras e não emprego nem mesmo letras. [...] nos trinta anos que escrevo não encontrei ainda totalmente / não meu verbo e minha língua, / mas o instrumento que não cessei de forjar. / Sentindo-me analfabeto iletrado, esse instrumento não se apoiará sobre as letras ou sobre os sinais do alfabeto, ainda estamos aí perto demais de uma convenção figurada, e ocular e auditiva". A seqüência do texto analisa essa "convenção figurada", a que "ligou" "o sentido", "o pensamento" e as "tábuas formais escritas": isso consiste ainda em "projetar". A "projeção" ocorre nas "paredes de um inverso cérebro": "um caráter é um movimento prescrito que vem uma vez mais projetar a porra de um último fósforo, / e logo todas as palavras serão lidas, / todas as letras completamente esgotadas" (ibidem: 137).

De certa forma, a saturação desse estado mostra um limite cuja a convulsão das palavras projetam toda uma virtualidade que não está nelas mesmas. Pensando na materialidade da voz, sua vibração enquanto fenômeno físico, Artaud parecia ainda ver no teatro um suporte que, diferentemente do texto escrito, ainda podia suportar uma voz como a que a glossolalia reclamava. Ao mesmo tempo, todo este revolver enquanto criador, foi engendrado na impossibilidade da cena. $\mathrm{O}$ que se pode gritar numa escrita é verdadeiramente limitado ao que se pode gritar numa cena. Portanto, se ele procura esgotar a letra, o que é possível depois disso? Se não se pode apoiar sobre as palavras, as letras ou sinais do alfabeto, o quê servirá de 
suporte para outras possibilidades de vocalizar? Nem toda a voz cabe na língua e, diferente de um léxico, a voz é inesgotável.

Se voltarmos o olhar microscópico para nossos corpos, perceberemos de fato que, antes de sermos discurso ou língua, somos matéria com vastos espaços vazios, uma matéria que vibra, que é som e, se voltarmos nosso olhar para um panorama macrocósmico, perceberemos que o universo é sonoro. Não haveria aqui uma heterogênese que abarca o inorgânico, cujas as possibilidades vocais podem investir num devir cósmico, ao mesmo tempo em que uma noção de limitrofia parece ponderar o investimento de desejo? O que seria vocalmente viável se eu buscasse cantar uma estrela ou um tronco submerso no oceano? Certamente eu teria que transcender uma noção alfabética, à palavra, ao discurso, mesmo figuras como a metáfora não fariam muito sentido num devir-vocal-estrela. Também não se trata de reprodução ou sonorização de objetos, mas de criação, tatear limites, e possibilitar que o insólito ganhe alguma forma em seu espectro vocal. No estranhamento diante dessas realidades, cantar uma estrela pode ser uma incubação, imersão, ampliação das possibilidades vocais,

...fazer a linguagem servir para exprimir o que ela não exprime habitualmente [...] é servir-se dela de maneira nova, excepcional e não costumeira, é dar-lhe suas possibilidades de abalo físico, é dividi-la e repartila ativamente no espaço, é tomar as entonações de maneira absolutamente concreta e restituir-lhes o poder que teriam de dilacerar e de manifestar realmente algo, é voltar-se contra a linguagem e suas fontes vilmente utilitárias, poder-se-ia dizer alimentares, contra suas origens de fera acuada, é enfim considerar a linguagem sob a forma do Encantamento" (Artaud apud Derrida, 1998: 56-57).

Há aqui uma referência às leituras sobre a Cabala, cujas entoações ganham um aspecto mágico, restituindo um valor primeiramente material à palavra, mas ainda voltada para a linguagem, ainda que fazendo-a delirar ou escoar para fora de sua utilidade, para além de seus hábitos. As glossolalias em Artaud acompanham a língua, a língua que passa por cirurgias, uma língua que suporta intervenções dramatúrgicas, que perde a sua medida e que ainda funciona como escrita, mas também acompanha toda a insuportabilidade linguística, de forma a desejar ser inteiramente voz, som. "Acredita-se, às vezes que essas variações não expressam o trabalho comum da criação na língua, e permanecem marginais, reservadas aos poetas, às crianças e aos loucos" (Deleuze e Guattari, 2002: 44), mas há quem, na incansável força de criar, faz dessa marginalidade seu caminho cruel. Em Artaud a voz sugere-se, matéria virtual, 
busca linhas para ser experimentada, insere-se numa noção de devir molecular. Insinua uma experimentação de sonoridades. Suas glossolalias, vozes sem órgãos, buscam experimentar um limite, pactuar com fenômenos de borda, ser abertura para outros sentidos implicados na vocalidade para a performance. Forçar algo, renunciar a algo, ultrapassar algo, deixar passar algo, reter, implodir, explodir, trata-se de engendrar universos dentro de si, fazê-los escapulir boca afora, fazê-los ruir com um som que se agarra enquanto se devém. Ser a própria voz. 


\section{antistratosquo}

Imagine uma placa em praça pública, numa cidadezinha italiana, com um nome e, abaixo dele, os dizeres 'sperimentatore della voce'. Eis aquele que desafiou limites fisiológicos, políticos e culturais da produção vocal em performance: Demetrio Stratos. A placa é real, assim como parece irreal a multiplicidade de experiências às quais se lançou na pesquisa da voz. Stratos foi uma figura singular na música contemporânea, pois possibilitou uma via experimental vocal cujo o ressoar ainda suscita muitas perguntas.

Stratos ousou dar um sentido amplo de libertação por meio da prática vocal. A despeito de ser músico, suas pesquisas apontavam uma inquietude peculiar em relação às possibilidades da voz em intersecção com vários campos do saber como os estudos da linguagem, da psicanálise, da política, da etnomusicologia e um senso multiplicador de experiências na área da performance, como a poesia sonora, pop rock, canto erudito, cantos e técnicas de outros povos, teatro e dança.

No que toca a esta pesquisa, a importância de Stratos é sobretudo relativa às suas experiências solo na exploração dos limites fisiológicos de uma voz humana e seus parâmetros. Numa perspectiva pouco usual em relação ao canto, cujos limites com uma fala faz-se aqui evidenciar, ele vai propor uma incessante investigação de si a partir de muitos contextos culturais no uso da voz. A fealdade e o estranho dentro de determinados estratos do canto e da própria emissão vocal, serão o foco de estudos que vão fazer tropeçar ou gaguejar o discurso. Sua noção de voz incluía o ruído, o excesso e a sujeira como elementos prolíficos de uma vocalidade nômade. A onomatopeia e os balbucios da criança em fase de aprendizado linguístico, por exemplo, são elementos utilizados na busca por uma sonoridade vocal. "Pensa-se numa escuta 'bruta', som após som, aquela que aceita tudo, sem discriminações culturais; escuta do desejo, da corporalidade, do despudor e da vida" (Haouli, 2002: 39), aceitar toda a voz possível para sempre vislumbrar um horizonte ainda vasto a ser descoberto. Prática libertadora da voz, investigadora de si, imersiva, subreptícia, aberta aos seus subterrâneos, prolífica, estranha.

Dessa forma, uma noção musical voltada para as possibilidades de uma voz glossolálica se mistura às formas de enunciação, embaçando ainda mais as fronteiras daquilo que ela requisita. Mais um acesso às linhas de fuga: "A voz na música nunca deixou de ser um eixo 
de experimentação privilegiado, jogando ao mesmo tempo com a linguagem e com o som" (Deleuze e Guattari, 2002: 39), e é sob este privilégio que o ritmo, a melodia e a harmonia podem fazer o excesso de uma glossolalia devir em outras expressões e manifestações.

Stratos requisita todo o som da voz: o peso e a leveza do som ruidoso, de uma voz rasgada, atritada, polifônica, da respiração como elemento vocal, do som da língua e da saliva e outros micro-sons bucais e toda expressão bruta de uma vocalidade que parece bárbara, estrangeira de si. É curioso o fato de que Stratos fez uma leitura de 'Para acabar com o julgamento de Deus' $^{72}$, numa série organizada pela France Culture. Certamente o espectro amplo de possibilidades da voz nesta obra, que é até hoje um marco da experiência vocal em performance, parece ter feito ressoar seu desejo. Ele faz todas as vozes, deixando passar um coeficiente de estranheza na exploração dos parâmetros do som a partir de Artaud.

O que se passa em 'Passagi 1,2 ${ }^{173}$ ? Posso imaginar o som de uma morte? Um ser de outro planeta? Uma voz magmática, mineral-animal, som da terra, som de um imenso animal antigo, uma grande cavidade ruminante, o atrito do ar no sopro, agudíssimos, os últimos sons de alguém que atravessa um limiar? O que me foi tirado, que muitas vezes me impossibilita de mergulhar numa sonoridade assim? Para além da apurada técnica de Stratos, como posso devir enquanto escuto esta canzornebrga ${ }^{74}$ ? O que se perdeu? Rosolato comenta que

Nós, adultos, reduzimos a grande variedade de ruídos que podemos produzir e só retemos aqueles que permitem a melhor comunicação. São abandonados ou passam despercebidos os ínfimos movimentos musculares da laringe e do sopro, ensaios abortados ou elementos componentes, iniciais ou intermediários, de expressões especializadas da voz (Rosolato apud Haouli, 2002: 47).

Na mesma medida em que reduzimos os ruídos do nosso discurso e limpamos nossas vocalidades (da cena, das liturgias religiosas, dos diálogos de cada dia,..) também perdemos a capacidade de perceber e desejar uma sonoridade cujo aspecto bruto propaga outras imagens, outros sentidos, outras reações psicofísicas. Pensar numa repressão da produção vocal, é também pensar na repressão de sua escuta: sons brutos, uma dissonância, um agudo estridente, algo como um grito de porco no abate, um choro pavoroso, uma voz tão pequena e tão

\footnotetext{
72 Trecho da performance de Stratos: http://www.youtube.com/watch?v=G6nGSNI--qU.

${ }_{73}^{73}$ Faixa de 'Cantare la voce' de Stratos (http://www.youtube.com/watch?v=y0YKmrbeTic).

${ }^{74}$ Seminsh-semis oen grrrrarrrrr di cancionnis en vishgrrrr.
} 
desmedidamente humana, que quase se perde em suas micro sutilezas, uma prece inventada numa linguagem inexistente, uma melopeia infinda e monótona, pequenos silvos, sutis asperezas... Desperdiçar os sons não é dar outros contornos à voz?

Poderíamos pensar numa vocalidade como excreção: vomitar ruídos que interfiram e que recoloquem a voz da Voz, uma emanação dos prazeres sem repressão. Pensar uma vocalidade do desperdício que comunique além da palavra, na qual mesmo o sopro - sem o qual nenhuma voz existe nem o canto é possível - passe a ser escutado [...] escuta das multiplicidades, dos sons que não podemos mais possuir ou rotular com nossos pálidos gostos (Haouli, 2002: 50).

Política e poética do desperdício: dar passagem ao que não conseguimos domesticar, naturalizar, banalizar, que escapa selvagem, indomável e, quando um potencial estranho se torna um território, uma outra potência assola nosso quintal, pois existe voz para além da voz que conhecemos e talvez o mais importante seja perceber que o horizonte da voz se derrama para além dele mesmo. Certeau fala do selvagem como passageiro: "Ele se marca (por manchas, lapsos, etc.), mas não se escreve. Altera um lugar (perturba-o), mas não funda nenhum" (2011: 226), é a violência de uma desordem, algo que não podendo ser apreendido, exige a passagem como uma pulsão.

Já escutou a si mesmo na pura meditação de escutar-se? Sem ninguém por perto, sem interferências que não as suas? No umbral da noite, sem os vizinhos, sem os familiares? Lembra-se do pacto? Mesmo sem alterar muito os parâmetros já conhecidos e habituados de sua vocalidade, não soa estranho? Falar sozinho(a), resmungar, cantarolar. Consegue ouvir sua própria voz, a sós, você e vocês, pois você é legião, por uma hora inteira numa madrugada qualquer? Indo um pouco além de sua voz habitual e domesticada, consegue esganiçá-la um pouco que seja, abobá-la, ridicularizá-la, deslocá-la de seu métron? Perceber que o estranho está aí, que faz parte de você. Escutar-se abertamente, pode colocá-lo diante das possibilidades de produção vocal aqui tratadas, que vão ao encontro das possibilidades de escuta. Escutar-se pode ser uma experiência entre, que muitas vezes suscita alianças.

Para Haouli a liberação da voz em Stratos é uma liberação do corpo, trata-se de "redimensionar as capacidades ruidísticas dentro de sua especificidade 'bruta' e material" (2002: 57). Estamos falando de uma voz que reclama a improvisação e o desafio constante de experimentar com o desconhecido. Não há neutralidade aí. Atemporalidade vocal, por uma 
voz que conquiste aberturas, estímulos vibratórios, que conquiste territórios de sonoridades e que novamente desorganize estes territórios. É o conjunto de práticas de um corpo sem órgãos: experimentar, experimentar, experimentar.

Zumthor diz que "A voz se diz enquanto diz; em si ela é pura exigência" (2010: 11), neste sentido, ela é presença, ela acontece enquanto reatualização instantânea de um corpo que está presente. É a exigência da performance. A voz de Stratos reitera a presença do som, a matéria tímbrica, o rasgo do grito, a estranheza do que precisa ser desvelado enquanto matéria bruta, plena de impurezas, ao mesmo tempo em que também exige certa sofisticação técnica enquanto percepção sutil, uma intuição desperta para percorrer os territórios, capacidade de improvisação e entrega. O rumor de um aquém e uma além da linguagem desejando passar.

As vozes que não são comportadas, compreensíveis, reconhecíveis, palatáveis enfim, desejam uma entrega na escuta, um movimento de alteridade que procura a experiência, pois escutar é também outrar-se. Há algo que não seja palavra? Que não seja um nome? Não se trata de espacializar a palavra, não se trata de uma arquitetura lexical e não se trata absolutamente de língua-base para estas experiências. E se não se trata de nada disso, nem de recalque, nem de regressão, nem de caos gratuito, trata-se de quê? De uma entrega a uma potência sonora que virtualmente agrega um manancial da experiência vocal possível. Novamente e sempre: o que pode a voz?

As emoções mais intensas suscitam o som da voz, raramente a linguagem:
além ou aquém desta, murmúrio e grito, imediatamente implantados nos
dinamismos elementares. Grito natal, grito de crianças em seus jogos ou
aquele provocado por uma perda irreparável, uma felicidade indizível, um
grito de guerra que, em toda a sua força, aspira a fazer-se canto: voz plena,
negação de toda redundância, explosão do ser em direção à origem perdida -
ao tempo da voz sem palavra (Zumthor, 2010: 11).

Sim, existe algo que esquecemos em possíveis sonoridades que perpassaram nossa constituição e a constituição da natureza, há também um apelo instintivo nestas imersões, mas antes de um retrocesso, vislumbra-se uma ressignificação sonora que aponta para novas criações. Não se trata de uma produção metafórica de uma voz primeva, antes, uma produção desejante. Foi observando sua filha em idade anterior ao aprendizado da língua que Stratos pôde perceber a rica multiplicidade da voz humana no jogo das sonoridades feito pelas crianças. Uma voz sem nome, sem sujeito, sem significado determinado, sem ponto fixo: "ela 
pertence a todo o gênero humano sem exceção, porque possui timbre, corporalidade e emoção comuns à nossa liberdade perdida" (Haouli, 2002: 92).

O nomadismo busca outras cartografias, e uma voz assim é irrefreável, ela vai fecundar sempre com outros territórios desconhecidos, é como uma revoada de pássaros esganiçados forçando os grasnidos pelo aparelho fonador, pelos poros. O que se passa em 'Criptomelodie infantili $^{175}$ ? Uma melodia infantil, brincadeira adormecida na matéria da fonação, um retorno a uma memória antiga na capacidade de brincar com o som e jogar com a voz. Onde se esconde a voz? Nesta ruidosa melodia toda uma corporeidade se faz presente na emissão vocal, em estalos, atritos, pressão e relaxamento de pequenos músculos, a passagem do ar como um motivo áspero atravessando toda uma investigação rumorosa. O quê esconde a voz? Assim como em 'Passagi 1,2', há uma liberdade poética na escuta, aguçada pelo estranho, há um sentido visceral, há um apelo físico do som, ele movimenta a imaginação e átomos. Uma melodia desconhecida, oculta nos subterrâneos de nosso corpo, de nossa voz: cripta de segredos sonoros, uma infância brincante do som na voz.

Cartografias de um experimentador da voz: influências profundas da cultura mediterrânea, música árabe, cantos litúrgicos, rock \& roll, militante político da juventude italiana anos 60 e 70, grava 'Pugni chiusi' ${ }^{76}$, participa do grupo de rock I Ribelli, funda o Area, grupo de rock progressivo com influências multi-étnicas, dedica-se a pesquisa da voz mantendo contato com centros de estudos especializados em fonética e fonaudiologia geral, pesquisa a psicanálise e sua relação com a voz, publica textos científicos, grava com a vanguarda da música erudita contemporânea, mantém uma parceria com John Cage... Práticas intensivas, diversas, um mergulho no som. Seu trabalho solo procurou tocar aquilo que não pode ser tocado pelas palavras, assim, foi arrastado para uma incrível pesquisa vocal. A voz de Stratos era atípica ${ }^{77}$ e isso o lançou para além dos próprios limites da voz humana comum. Se "O ruído, o 'desafinar' devem ser exorcizados daquele mundo que determinou uma certa 'moral da voz'"(Haouli, 2002: 75), Stratos era este ímpeto anárquico, o porta-voz de uma peculiar coragem vocal.

\footnotetext{
${ }^{75}$ Faixa de 'Cantare la voce' de Stratos (http://www.youtube.com/watch?v=6kxIWWW1_GQ).

$76 \mathrm{http} / / / \mathrm{www}$. youtube.com/watch?v=82m9fhoQi2o.

${ }^{77}$ No livro de Janet El Haouli (2002) há algumas referências da potência vocal de Stratos, como análise espectrográfica e comentários de fonoaudiólogos. Em seu site oficial, www.demetriostratos.org, pode-se consultar referências diversas sobre o alcance e a singularidade de sua voz .
} 
Recorrendo ao lúdico, Stratos procurou na onomatopeia, na voz das crianças e em vocalidades étnicas, as possibilidades inventivas da pesquisa vocal. Por sua desvinculação da palavra, o apelo ruidoso e excessivo, pela estranheza dos timbres, ele possibilitou uma exploração sonora impactante. Como diferencial em relação a maioria dos casos citados por Pozzo (2013) em relação às glossolalias lúdicas, que tinham na transgressão linguística uma forma de investigar outras sonoridades para a voz, Stratos, a priori, não investiu na palavra, na literatura ou no texto de forma geral, sua pesquisa tem no som a matéria-prima de suas criações. O som da voz. Um mesóstico ${ }^{78}$ de John Cage vislumbra o além que a voz de Stratos requisitava:

$$
\begin{gathered}
\text { to have haD } \\
\text { the idEa } \\
\text { his Music } \\
\text { would nEver } \\
\text { sTop } \\
\text { the Range } \\
\text { of hIs } \\
\text { vOice }
\end{gathered}
$$

$$
\begin{gathered}
\text { would have no limitS } \\
\text { nexT } \\
\text { foR him } \\
\text { to leArn } \\
\text { was in Tibet } \\
\text { after that Out } \\
\text { into vocal Space }
\end{gathered}
$$

Para que se possa imaginar e perceber que o devir da voz não cessa, ele adentra, abre, pois é coletivo, é cósmico, e...

\footnotetext{
${ }^{78}$ Para Massaud Moisés (1997), o mesóstico, composição poética, do grego mesóstichon, composto de mesos, médio e stíchos, verso, é uma variante do acróstico, que se compõe de letras ou sílabas que são colocadas no meio de um verso e cujas iniciais formam um nome ou uma frase, diferindo do acróstico propriamente dito por neste a composição da palavra estar no começo dos versos, e do teléstico, que situa-se ao final.

79 Tradução livre: para se ter / a ideia / sua música / nunca iria parar / o alcance / de sua / voz / não teria limites / para ele / o próximo / aprendizado / estava no Tibet / depois disso / além, espaço vocal adentro
} 


\section{...babelybablelyblablelyblablabely...}

Andrei Bely ${ }^{80}$ escreveu uma obra que não poderia passar despercebida aqui: Glossolalia - Um poema sobre o som $^{81}$. Nesta narrativa poética ele buscou uma alegoria rítmica, míticosimbólica, que não intentava uma transgressão da língua, mas um estudo pormenorizado sobre a fonética e o ritmo voltados para um ideário da natureza em formação. Ele vai ao encontro das raízes poéticas da língua. Novamente as aliterações, as assonâncias e as onomatopeias contribuem para uma investigação sobre as dinâmicas do som. Para ele a palavra era uma intensidade de ritmos e são "[...] memórias do som de um antigo significado" (Bely, 2001: 03, tradução nossa $)^{82}$. Seu poema traz uma ideia cosmológica do aparelho fonador e do dizer, como ritmos de uma natureza anterior, magmática, enigmática, passional, pré-conceitual. As imagens da terra, cuja formação conflui para o magma, as formações rochosas, e todos os elementos naturais que atravessaram a constituição da terra fazem parte de uma poética ligada à língua, à fala, ao som, primordialmente.

Para ele há o som e as imagens que se depreendem do som, no entanto são dimensões que não estão necessariamente ligadas. $\mathrm{O}$ som suscita suas próprias realidades. Ele analisa uma possível origem do falar, uma sombra antiga das palavras, uma mítica de ritmos que carrega a linguagem para as profundezas de uma natureza da origem dos tempos, lembrando as utopias de uma possível linguagem original, adâmica, motivo recorrente em pesquisas voltadas para práticas de uma glossolalia lúdica. Dessa forma, a onomatopeia, enquanto figura de linguagem, parece apontar as eclosões sonoras de um universo primevo. Pozzo cita a figura da onomatopeia como uma tipologia expressiva original que já era tratada no 'Cratyle' de Platão, cujas possibilidades sonoras tinham um valor rítmico na aurora da expressão vocal do homem:

Estendendo esta perspectiva, imagina-se em seguida que as primeiras expressões do homem tinham um caráter instintivo e passional ou que eles se caracterizavam pela entonação e acentuação rítmica da voz. Chegou-se a crer que era possível compreender o pensamento de um indivíduo através apenas de um discurso desprovido de sentido, tendência que abriu caminho aos

\footnotetext{
${ }^{80}$ Pseudônimo de Boris Nikolaevich Bugaev (1880-1934). Poeta, teórico e crítico literário russo, conhecido por sua pesquisa sobre o ritmo e a linguagem.

${ }^{81}$ Há uma versão online traduzida do russo para o inglês por Thomas R. Beyer Jr., que pode ser consultada no link - http://www.academia.edu/3078119/Andrei_Bely_GLOSSOLALIA_A_Poem_about_Sound_Translated.

82 "[...] memories of the sound of an ancient meaning".
} 
estudos recentes realizados no domínio do simbolismo fônico (2013: 224, tradução nossa) ${ }^{83}$.

Tal simbolismo tem em Bely explícitas influências de uma literatura hermética e ocultista como os conhecimentos alquímicos, as práticas da Cabala e alusões diretas a Rudolf Steiner $(1861-1925)^{84}$ e Jacob Boehme (1575-1624) ${ }^{85}$. Seu texto deve ser visto, antes de mais nada, como uma investigação da poesia por meio do som, numa improvisação cujos temas são imagens acústicas. Uma cosmogonia da linguagem enquanto movimento sonoro. Recorrendo a estudos filológicos das raízes de línguas indo-europeias, ele faz uma narrativa da criação do mundo, tal como o Gênesis bíblico, atribuindo um valor fundador do som, implícito nas palavras e letras.

A imagem do dançarino, com ressonância do Zaratustra de Nietzsche, dá à língua, enquanto órgão fonador e enquanto linguagem, um mover baseado em ideais da Euritmia, que seria a arte do movimento para expressar o som, numa relação direta com a palavra falada e com a poesia. O poema segue um princípio de associações por meio de imagens sonoras, pois a inspiração é sempre rítmica e fonética.

A imaginação e a ciência perscrutam as possíveis origens das primeiras expressões vocais do homem e grande parte das pesquisas apontam para sonoridades que se faziam presentes no nascimento das letras, guardando um sentido rítmico, relacionado aos parâmetros do som. Para Bely "A escuridão do significado do som está nos glossários a partir dos quais a humanidade construiu os templos dos dialetos" e se "nós criamos pessoas com palavras e as palavras são atos" (ibidem: 04-05, tradução nossa) ${ }^{86}$, somos ritmos reverberados na matéria e condensados em corpos prenhes deste som primordial. A glossolalia aqui é o balbucio da terra, uma terra antiga, que rumina o som quando ele não tinha sentido como conceito. Este som construía o cosmos em sua dança rítmica, e sua sonoridade telúrica é vislumbrada no falar.

\footnotetext{
83 "Prolongeant cettee perspective, on imagina insuite que les premières expressions de l'homme avaiente un caractère instinctif et passionel ou qu'elles se caractérisaient par l'intonation et l'accentuation rythmique de la voix. On em arriva alors à croire qu'on pouvait comprendre la pensée d'un individu à travers la seule prononciation d'un discours dépourvu de sens, tendance qui a ouvert la voie aux études récentes menées dans le domaine du symbolisme phonique".

${ }^{84}$ Foi fundador da Antroposofia, da Pedagogia Waldorf, da Agricultura Biodinâmica, da medicina antroposófica e da Euritmia. Esta teve grande influência no poema de Bely, por ser uma dança, cuja relação entre o movimento e a palavra contribuiu para uma noção da relação entre o som e o sentido em sua cosmogonia sonoro-poética.

85 Filósofo e místico alemão de tradição luterana.

86 "[...] the darkness of sound meaning is - in the glossaries, from which humanity has constructec the temples of dialects [...] we create people out of words; and the words are acts".
} 
Bely se aprofunda nas letras, vogais e consoantes, de forma a delinear resquícios míticos e herméticos que compreendem a forma de enunciá-los. Para isso traz uma referência poética ao lado de explicações técnicas sobre a articulação do som. Nesta, a língua, enquanto órgão da fonação, tem um papel preponderante sobre a enunciação, vinculando seus movimentos aos de um dançarino que volteia na caverna bucal. Se não tivéssemos língua teríamos palavras? Isto nos leva a imaginar um longo processo de sofisticação da língua enquanto órgão da fonação e seu papel na articulação e vibração vocal. Os sons existiam mesmo antes do homem existir, onde está esta memória antiga? Até onde nossas linguagens guardam os sons que ecoaram os princípios? Uma algaravia mineral sob as palavras, uma glossolalia cuja manifestação é o próprio cosmos devindo sua matéria, numa longa escala cósmica até a voz humana dos nossos dias. A glossolalia em Bely aponta para o enigma que vem do cosmos, explosões primevas, "o fluxo do ar, esse dançarino do mundo, é nossa língua" (ibidem: 03, tradução nossa) ${ }^{87}$. De alguma forma, suas concepções apontam para uma materialidade do som como princípio criador, de forma que a voz é um caminho, microcosmo, de enunciação do ritmo enquanto fundador do mundo.

87 "[...] a stream of air - this dancer of the world is - our tongue". 


\section{glossololalium}

A glossolalia se confunde com uma série de palavras, práticas e fenômenos, com as quais, de alguma forma, ela faz intersecção, relacionando-se poético-conceitualmente. Ela foi apropriada por diversos contextos em várias áreas do conhecimento, com fontes distintas no espaço-tempo. Entre práticas litúrgicas mítico-religiosas, psiquiátricas e artísticas, segue um pequeno glossário de termos, cujas aproximações creio oportunas para a prática da voz em performance numa pesquisa sobre glossolalia. Na verdade, trata-se antes, de um pseudoglossário, pois ele transcende a função do glossário, permitindo comentários, que podem ultrapassar a definição dos termos aqui tratados. Poroso, ele não esgota as possibilidades de referências afetas à glossolalia, antes disso, funciona como abertura às zonas indiscerníveis, fazendo ressoar uma poética do entre.

\section{algaravia}

Silveira Bueno a define como uma "linguagem obscura, errada, confusa, incompreensível. Var. algarabia - língua de mouro, língua árabe, considerada incompreensível pela maioria das pessoas simples. Vem de a-arabiia, a língua árabe em cruzamento com Algarve" (1964: 164). Algarve refere-se às feiras, lugar em que uma certa babel ressoa e faz-se perceber uma sonoridade indiferenciada, burburinho, vozerio.

\section{babel}

A Torre de Babel, mito cristão narrado no Gênesis, capítulo 11, do Antigo Testamento, fala da pretensa ascensão dos homens ao céu, por meio da construção de uma gigantesca torre. No entanto os homens são punidos por tal arrogância. Jeová ou Javé, do hebraico Iahweh, instaura uma confusão de línguas, de forma que os homens não mais conseguem se comunicar no intento de construir a torre e são dispersados pelo deus. No relato bíblico, Javé diz: "Eis que todos constituem um só povo e falam uma só língua. Isso é o começo de suas iniciativas! Agora, nenhum desígnio será irrealizável para eles. Vinde! Desçamos! Confundamos a sua linguagem para que não mais se entendam uns aos outros" ${ }^{88}$. Então "Iahweh os dispersou daí por toda a face da terra, e eles cessaram de construir a cidade. Deu-se-lhe por isso o nome de

\footnotetext{
${ }^{88}$ Bíblia de Jerusalém (2003: 48).
} 
Babel, pois foi aí que Iahweh confundiu a linguagem de todos os habitantes da terra e foi aí que ele os dispersou sobre toda a face da terra" 89 .

Nas notas referentes à narração são feitos comentários sobre o hibridismo dessa tradição, trazendo ponderações que apontam para uma possível explicação para a diversidade dos povos e das línguas, diz ainda que "Babel é explicado pela raiz bll, 'confundir'. O nome de Babilônia significa, na realidade, 'porta do deus'"'90.

É muito comum na tradição cristã, relatos de uma manifestação divina por meio de diversos níveis da linguagem. Assim como Deus desceu e proliferou uma balbúrdia linguística no relato do Gênesis, há o relato do milagre de Pentecostes, nos Atos dos Apóstolos, capítulo 2, já no Novo Testamento, em que o Espírito Santo desce e se reparte em línguas de fogo sobre uma assembleia, ocasião em que todos ali presentes começam a falar em outras línguas (aqui uma referência à glossolalia), ao mesmo tempo em que compreendem tudo em seu próprio idioma. É como uma Babel às avessas, pois aqui, uma ideia de glossolalia é que dá um sentido à experiência sonora. Além de estudos mítico-religiosos acerca do mito de Babel, outras áreas do conhecimento também se debruçaram sobre seus possíveis significados, como é o caso da psicologia, da arte e da linguística. Tal relato poético traz indagações simbólicas e aborda, intuitivamente, aspectos das formações linguísticas, sua diversidade e, de forma genérica, apontam caminhos para a origem múltipla da língua.

De fato, quando se fala em Babel, remete-se, comumente à incompreensão de múltiplas línguas em confusão, como num burburinho, como numa algaravia. Mário Eduardo Viaro ${ }^{91}$, apontando possíveis interpretações do mito, comenta sobre a diversidade tímbrica relacionada às línguas da época em que foi escrito o antigo testamento, ou seja, a confusão gerada por Javé, pode fazer uma possível referência, ainda que intuitiva, às diferenças sonoras, mesmo dentro de uma mesma língua, o que podia gerar a incompreensão na tentativa de comunicação entre diversos grupos. A narrativa mítica pode apontar para uma diversificação sonora e heterogeneidade linguística, ao lado de possibilidades simbólicas.

O dicionário Houaiss (2008) traz as seguintes entradas para o verbete: confusão, mistura de línguas, confusão de vozes, grande algazarra, movimentação barulhenta de pessoas, balbúrdia,

\footnotetext{
89 idem.

90 idem.

${ }^{91}$ Coordenador do Núcleo de Pesquisa em Etimologia e História da Língua Portuguesa da USP. Artigo in Língua Portuguesa, ano 9, número 100, 02/2014.
} 
tumulto, reunião de diversos elementos, complexidade, interferência proveniente de um elevado número de canais de informação, entre outros.

\section{blablação}

Exercício de improvisação teatral utilizado por Viola Spolin:

[...] significa simplesmente, a substituição de palavras articuladas por configurações de sons. Não deve ser confundida com 'duplo sentido', onde palavras reais são invertidas, ou mal pronunciadas, para confundir o significado. A blablação é uma expressão vocal que acompanha uma ação, não a tradução de uma frase portuguesa. O significado de um som na blablação não deve ser compreendido, até que o ator o transmita por meio da ação, expressões ou tom de voz. [...] desenvolve a linguagem expressiva física, que é vital para a vida no palco, quebrando a dependência das palavras para expressar o significado. Pelo fato de a blablação usar os sons da linguagem, subtraindo dela os símbolos (palavras), coloca o problema da comunicação no nível da experiência direta (2001: 108).

Este é um exercício muitas vezes confundido com o grommelot, termo que também é definido nesse glossololalium. É muito utilizado em contextos pedagógicos de sala de aula, oficinas de iniciação teatral e práticas de palhaço. É um recurso que possibilita a espontaneidade do gesto e a liberação da voz entre outros fins.

\section{gibberish}

Este é um termo muito vago, cujas fontes são muito obscuras e pouco fidedignas, mas que no entanto, abarca aspectos que fazem intersecção com quase todos os termos aqui tratados. Refere-se comumente à ininteligibilidade de discursos, escritos ou falados, também à incompreensão de línguas diferentes do inglês britânico, cuja origem, ao termo é vinculado. Como muitos termos aqui tratados, pode denotar uma origem onomatopeica e imitativa, como o burburinho de uma conversa. O dicionário Collins ${ }^{92}$, além de vincular o termo à incompreensão de uma conversa e ao nonsense, termo também definido nesse glossololalium, também faz referência ao modo rápido com que os macacos dialogam. Já o dicionário Oxford $^{93}$ faz referência à ininteligibilidade dos discursos falado e escrito, denotando também uma língua estrangeira como o espanhol, o sueco, entre outras, ou seja, uma língua distinta do inglês. Também relaciona o termo à palavra gibber, que faz referência ao falar de forma

\footnotetext{
92 http://www.collinsdictionary.com.

$93 \mathrm{http} / / / \mathrm{www} .0 x$ forddictionaries.com/us/.
} 
rápida e ininteligível, geralmente por medo ou choque. Vale lembrar que o medo e o choque também provocam fenômenos como a gagueira e dificuldade na articulação de sons e palavras, frequentemente levando à incompreensão do discurso. Uma versão online do Etymology Dictionary ${ }^{94}$ faz referência à imitação do som de uma conversa, provavelmente influenciado por jabber que relaciona-se ao tagarelar. Esta versão também aponta para a linguagem de bandidos e ciganos, lembrando algumas variantes do jargão, termo definido nesse glossololalium.

\section{glossopoese}

Para Israel Noletto, a glossopoese é uma:

Parte da Linguística que se dedica a estudar a estrutura, as origens e o desenvolvimento de idiomas naturais com o objetivo de, a partir desses idiomas ou apenas dos conceitos obtidos, desenvolverem-se línguas artificiais, isto é, línguas que não surgiram dos processos linguísticos naturais, porém, foram literalmente construídas artificialmente por um indivíduo ou grupo pequeno (2011: 20-21).

A invenção de idiomas é uma prática comum no cinema e séries contemporâneas. Como exemplo, David J. Peterson, linguista estadunidense, é um especialista em criação de línguas ficcionais que, entre outros trabalhos, inventou as línguas exóticas faladas no seriado 'Game of Thrones ${ }^{\prime 95}$. Outro exemplo é a língua artificial falada pelos Navi, uma raça alienígena, no filme 'Avatar' ${ }^{96}$ de James Cameron. Este idioma ficcional foi criado por Paul Frommer, professor especializado em linguística. Como toda língua, estas seguem regras gramaticais, comportam um léxico e, logo, podem ser escritas e faladas. Diferente do gibberish, da blablação e do grammelot, que são práticas de improvisação em contextos cênicos, estas línguas podem ser aprendidas como uma língua comum.

\section{glotolalia}

De acordo com Alessandra Pozzo (2013) a forma glotolalia, que seria um sinônimo de glossolalia é rara, no entanto existe designando o mesmo fenômeno. Demais, glote ou glota

\footnotetext{
94 http://www.etymonline.com.

95 Série de TV estadunidense, criada por David Benioff e D.B. Weiss para a HBO.

96 Distribuído por 20th Century Fox, EUA, 2009.
} 
que, para Silveira Bueno (1964) seria a abertura da laringe que dá passagem ao ar na produção da fala, deriva do latim glottis, que deriva do grego glotta, cujo significado é língua.

\section{grammelot}

Alessandra Pozzo que em seu estudo 'Grrr...grammelot. Parlare senza parole. Dai primi dalbettii al grammelot', se debruça sobre o trabalho do ator italiano Dario Fo, observa a importância de uma dramaturgia do espectador na construção de sentido em um discurso como o do grommelot, que certamente tem ressonâncias com a blablação. Demais, para ela:

O grommelot é uma linguagem teatral improvisada, não convencional e não articulada em palavras. Ela se apoia no sistema fonológico de uma língua verdadeira, que serve como 'língua de referência'. Trata-se não somente de línguas em que o ator opera uma paródia sonora, mas também de dialetos, jargões e barulhos de todos os gêneros (2013: 312, tradução nossa) ${ }^{97}$.

Como aponta Pozzo, foi um recurso muito utilizado por Dario Fo em seu trabalho como ator e clown, como por exemplo em seu espetáculo 'Mistero buffo' ${ }^{198}$. Em seu Manual Mínimo do Ator ele diz que:

Grammelot é uma palavra de origem francesa, inventada pelos cômicos dell'arte e italianizada pelos venezianos, que pronunciavam gramlotto. Apesar de não possuir um significado intrínseco, sua mistura de sons consegue sugerir o sentido do discurso. Trata-se, portanto de um jogo onomatopeico, articulado com arbitrariedade, mas capaz de transmitir, com o acréscimo de gestos, ritmos e sonoridades particulares, um discurso completo [...] Para a execução do grammelot é quase impossível ditar regras e muito menos sistematizá-las. Precisamos trabalhar com a intuição, fundamentados em um saber praticamente subterrâneo, sendo inviáveis o estabelecimento de um método definitivo e a transmissão do conhecimento em detalhes (1997: 97-98).

Antunes Filho ${ }^{99}$ a aportuguesou como gromelô, desenvolvendo várias experiências cênicas com linguagens inventadas, cindindo com a palavra convencional e brincando com os sons e o

\footnotetext{
97 "Le grommelot est un langage théâtral improvisé, non convencionnel et non articulé en mots. Il s'appuie sur le système phonologique d'une vraie langue, qui fait office de 'langue de référence'. Il s'agit non seulement de langues dont le comédien opère une parodie sonore, mais aussi de dialectes, de jargons et de bruits de tous genres".

${ }_{98}$ Teve uma primeira versão escrita e encenada em 1969 e, como a maioria dos espetáculos de palhaços, tem sido apresentado desde então com as adaptações em relação à resposta do público.

99 Diretor de teatro brasileiro, dirige o Centro de Pesquisas Teatrais (CPT), criado em 1982, em SP.
} 
gestual, como é o caso da peça 'Nova velha história' ${ }^{100}$. Assim como muitos termos aqui tratados, e mesmo a glossolalia, há uma relação com a onomatopeia e outras figuras poéticas da linguagem como as aliterações e assonâncias.

\section{jargão}

Peter Burke em sua pesquisa sobre as relações entre a linguagem e o meio social traz um mergulho neste verbete, relacionando-o a linguagem do submundo, linguagem hermética, às gírias em determinados contextos sociais e sua contribuição para uma sociologia da linguagem:

Jargão é uma palavra medieval, encontrada em provençal e em francês já nos séculos XII e XIII e, um pouco mais tarde, em inglês. Chaucer a usava para descrever o gorjeio dos pássaros. O termo era usado para se referir à fala ininteligível, um tipo de gargarejo [gargle] ("gargle" e "jargon" são palavras derivadas da mesma raiz (gabble), termo usado em inglês por volta do século XVI. Àquela época, a palavra já havia se espalhado para o italiano (gergo ou zergo), espanhol (jerga, jeringonza) e português ("geringonça"). [...] Para uma grande variedade de sinônimos, podemos recorrer ao French - English Dictionary de Cotgrave: "Jargon. Algaravia, linguagem empolada, gíria de ladrões; uma algaravia bárbara". "Jargonneur. Um palrador, dado a algaravias, um trapaceiro que fala empolado ou em uma linguagem que nem ele nem seus ouvintes entendem" (1996: 8-9).

É um termo que se relaciona com vários outros aqui definidos e cuja polissemia possibilita uma gama variada de sentidos. É muito comum referir-se ao léxico e à forma de falar de profissionais de áreas específicas do conhecimento como jargão: jargão jurídico, jargão da física, jargão do cinema, etc. Neste sentido, soa como uma linguagem ininteligível e pouco compreensível se você não faz parte do grupo que a emprega.

\section{lalíngua $^{101}$}

Tradução de Haroldo de Campos para o termo lalangue criado por Lacan. Associa-se à lalação do bebê, num jogo onomatopeico com lalia. Lalangue não pode ser aprendida e ligase à figura materna, que media sua relação com a linguagem. Não depende de significação, pois não é uma linguagem. Esta seria um poder de discursar sobre àquela, no entanto, somente

\footnotetext{
${ }^{100}$ Montada pelo CPT em 1991, com texto construído em uma língua imaginária, tendo como base o conto infantil 'Chapeuzinho Vermelho', dos irmãos Grimm.

${ }^{101}$ Há um texto no link http://www.ipla.com.br/estudos/trabalhos.html, do Instituto da Psicanálise Lacaniana IPLA, que sintetiza a noção de lalangue, cujas referências apontam também para o original de Lacan.
} 
o inconsciente manifesta lalangue. Dessa forma, ela se alia a um dos princípios básicos da psicanálise lacaniana que é a ideia de que o inconsciente está estruturado enquanto linguagem. Assim como a ideia de uma voz como resto e excesso apontada por Zizek a partir de Lacan, lalangue insere-se na psicanálise enquanto conceito baseado numa estruturação do inconsciente.

\section{lord chandos}

Em 1902, em Berlim, Hugo von Hofmannsthal publica sua carta fictícia. Esta é encaminhada por Lord Philip Chandos, personagem fictícia, a Francis Bacon. A carta de Chandos vem expressar uma profunda angústia existencial, uma doença do espírito, motivo pelo qual ele abandonará para sempre a carreira literária. Ele perdera a capacidade de pensar ou dizer algo a respeito da experiência humana. Chandos sofre de uma crise da linguagem, incapacidade de expressar em palavras qualquer evento por mais banal que seja, uma incapacidade de criar discursos coerentes e de emitir opiniões e julgamentos. As palavras perderam qualquer sentido possível e o fez naufragar num vazio amedrontador.

Para Chandos a retórica é incapaz de penetrar o coração das coisas, motivo pelo qual, a língua não o possibilita dizer mais nada e o lança na incapacidade de ser compreendido em qualquer língua. Há uma desagregação de conceitos em Chandos, a arquitetura do logos linguístico se desintegra, rui seus edifícios e é assolada pela natureza animal que o espreita. Há uma diluição cósmica do seu eu, ele parece indiferenciar-se do mundo em seus múltiplos devires, é o que Deleuze e Guattari chamaram de "participação anti-natureza" (2005: 21).

Era uma força animalesca e demoníaca que parecia se apossar de Chandos, "[...] uma participação monstruosa, um verter naquelas criaturas ou a sensação de que um fluido de vida e morte, de sonho e vigília vieram (mas de onde?) impregná-las por um instante" (Hofmannsthal, 2008: 131, tradução nossa) ${ }^{102}$. O fascínio diante do diabólico, o terror de um despedaçamento abissal: as portas de entrada para o animal. Diante de tal experiência, que voz transitaria o devir de Lord Chandos? Diante de uma tal afecção, como ele escreveria e, consequentemente, como falaria no lugar de um animal?: "Pois o afecto não é um sentimento pessoal, tampouco uma característica, ele é a efetuação de uma potência de matilha, que subleva e faz vacilar o eu" (Deleuze e Guattari, 2005: 21).

102 "[...] una participación desmesurada, un transvasarme en aquellas criaturas o un sentir que un fluido de vida y muerte, de sueño y vigilia había venido (de dónde?) por un momento a impregnarla". 
Perder a linguagem, a estruturação do pensamento, a articulação do discurso e das palavras é um acontecimento-limite para Chandos, por isso o horror diante daquilo que parece ser a instauração do caos. Ao mesmo tempo parece ser esta a crueldade necessária que faz revolver o mais profundo dele, uma perturbação sub-vertida. No final de sua carta, Chandos diz que a língua que lhe foi dada a escrever, não é uma língua conhecida, mas aquela dita pelas coisas emudecidas. E o que diz a ele uma língua que não fala?

\section{louis wolfson}

Wolfson singulariza de forma interessante a relação entre a linguística e a psiquiatria, evidenciando um procedimento peculiar na tentativa de matar sua língua materna: o inglês. Trata-se de um caso de esquizofrenia. Deleuze comenta o procedimento de Wolfson em Crítica e Clínica (2004), enquanto Foucault o relaciona com procedimentos do escritor JeanPierre Brisset e do poeta Raymond Roussel em seu texto 'Sete proposições sobre o sétimo anjo' $^{103}$. Em seu livro 'Le Schizo et les langues', Wolfson detalha seus experimentos para impedir que a língua materna o perturbe e fira seu corpo. Este combate também se relaciona com a voz de sua mãe, cuja sonoridade do inglês perpassa sua pessoa de maneira avassaladora.

Para isso, Wolfson cria um conjunto de experimentações para impedir o sofrimento em ouvir o inglês. Ele trabalha com princípios de uma tradução que permite transmutar o inglês para uma língua cuja "combinação fonética ou molecular" como aponta Deleuze, se apropria de sonoridades e significados de outras línguas como o francês, o alemão, o russo ou o hebraico. Numa operação de som e sentido, Wolfson simula uma língua que, apropriando-se de uma escrita fonética de outros idiomas intenta "formar uma totalidade líquida ou uma continuidade aliterativa" (Deleuze, 2004:26). Processos de colagem, reverberação e ressonância.

O procedimento de Wolfson leva a linguagem a um limite, no entanto, de acordo com Deleuze, ele não a transpõe, pois parece prisioneiro de um artefato linguístico cujo "o problema não consiste em ultrapassar as fronteiras da razão, e sim em atravessar como vencedor as da desrazão" (ibidem: 30). A história de Wolfson "é antes o que há de "impossível" na linguagem e que, por conseguinte, lhe pertence tanto mais estreitamente: seu fora" (idem) e, dessa forma seus procedimentos perfazem uma condição patológica, remetendo à loucura.

${ }^{103}$ In Estética: Literatura e Pintura, Música e Cinema da coleção Ditos \& Escritos vol. III (2013). 


\section{manuscrito voynich ${ }^{104}$}

Supostamente adquirido pelo mercador de livros Wilfrid Michael Voynich no colégio jesuíta de Villa Mondragone, em Frascati, em 1912, tal manuscrito é um verdadeiro enigma até hoje. Trata-se de uma obra cujo o texto parece ter sido inventado numa língua artificial, rico em desenhos coloridos com alusões à botânica, à astrologia, à medicina, a procedimentos da alquimia, entre outras referências.

A hipótese mais plausível é de que tenha sido escrito no norte da Itália, entre 1404 e 1438 d.C, de acordo com testes de carbono efetuados. Seu autor, a linguagem empregada e a data em que foi escrito são dados incertos. Nenhum linguista ou criptografista conseguiu compreender sua lógica, desvendá-lo ou decodificá-lo. Não segue o padrão fonético de nenhuma língua natural conhecida, mas também não se pode dizer absolutamente que se trata de uma língua artificial. Parece ser dividido em sessões e trazer informações sobre botânica, astronomia, astrologia, biologia, medicina e farmacologia, gráficos zodiacais, mapas celestes, receitas, fenômenos ópticos.

Há quem diga que se trata de um manuscrito feito por Leonardo da Vinci quando criança, ou um manual de magia medicinal, ainda um tratado alquímico ou mesmo um grande blefe composto de imagens alegóricas, um documento da imaginação fantástica e, por isso, acredita-se que pode nem mesmo possuir uma mensagem codificada. De qualquer forma, o manuscrito Voynich suscita a imaginação e a curiosidade de muitos pesquisadores, cujo o investimento de energia em investigações que incluem trabalhos de linguistas, criptografistas, biólogos, historiadores, químicos, demonstra a necessidade humana de procurar significado e sentidos diversos em suas criações. Ainda assim o manuscrito, repleto de desenhos, mapas e gráficos continua insondável, ininteligível e fora da compreensão dos curiosos, mostrando-se como o reflexo da imaginação de muitos pesquisadores, sem nunca possibilitar acesso aos seus segredos.

Como terreno fértil da imaginação, negando-se a um significado seguro, abre-se para a multiplicação de sentidos daquilo que não se pode decifrar e permanece desconhecido. Seu

\footnotetext{
${ }^{104}$ A maior parte das informações aqui sintetizadas pode ser consultada no documentário 'O misterioso código Voynich' da History, no site https://www.youtube.com/watch?v=QpWZ0x3x5G8. Demais, há várias cópias gratuitas em PDF na internet dando acesso à obra.
} 
original encontra-se na Beinecke Rare Book and Manuscript Library da Universidade de Yale, em New Haven, Estados Unidos.

\section{melopeia}

A melopeia em si não necessariamente se relaciona de forma direta com a glossolalia. $\mathrm{O}$ dicionário Houaiss (2008) traz os seguintes significados para o termo: 1 - a parte musical, melódica de um recitativo ('gênero declamatório'); 1.1 - melodia que acompanha qualquer recitação; 2 - toada, cantiga de melodia simples e monótona, ger. melancólica; cantilena; 3 toada doce, suave eufônica; 4 - declamação harmoniosa, delicada, aprazível; 5 - na Grécia antiga, o tratado de composição, o conjunto dos princípios, das regras que regem a composição de melodias; ainda melodia, música, teoria musical. No entanto, a melopeia é comumente utilizada em contextos mítico-religiosos em cantos secretos e iniciáticos, relacionando-se a uma estranheza peculiar e uma noção hermética de ensinamentos de um grupo. Existe inclusive uma variação do falar em línguas do contexto cristão que se manifesta de forma melódica: o cantar em línguas. Existem também as xenoglossias, termo também definido neste glossololalium, em canto e faladas. Outro exemplo que também lida com melopeias e faz referência à liturgia cabalística é a salmodia, termo que também é definido nesse glossololalium.

A melopeia também é citada por Aristóteles na Poética como parte da Tragédia, relacionada às partes cantadas e ao ritmo. Ezra Pound (2012), em seu livro 'ABC da Literatura', elenca a melopeia como uma modalidade de poesia, ou seja, aquela que é percebida enquanto sonoridade. No prefácio do mesmo livro, Augusto de Campos aponta a característica que fundamenta a melopeia, que é justamente o fato de as palavras estarem impregnadas de uma propriedade musical (som e ritmo), sendo isso que orienta seu sentido. Esta é uma característica peculiar da poesia dos trovadores, a exemplo de Arnaut Daniel, poeta provençal do fim do séc. XII.

\section{nadsat}

Linguagem criada por Anthony Burgess em 'Laranja Mecânica'. Denota a gíria de gangues de adolescentes no contexto narrativo do livro. Lembra o jargão, termo referido nesse glossololalium. Burgess era fascinado por gírias, dialetos, neologismos e o jargão de subgrupos. Fábio Fernandes, no prefácio da edição brasileira, observa que esse termo seria um 
transliteração para o idioma russo do sufixo inglês teen, que abrange as idades entre 13 e 19 anos e é traduzido em português como 'adolescência'. O vocabulário usado por seus personagens era basicamente uma mistura de russo com inglês popular, entre outras línguas eslavas e recursos linguísticos. Essa linguagem primava pelo estranhamento e imersão do leitor num universo conceitual que o transportaria para uma peculiar Inglaterra futurista, "uma anomalia na chamada ordem natural das coisas, algo que faz com que o leitor saia da sua realidade cotidiana e se depare com uma realidade não necessariamente reconhecível" de acordo com Viktor-Chklóvski, citado no prefácio da edição brasileira.

De acordo ainda com Fernandes, algumas das características do nadsat são a utilização do rhyming slang,

uma espécie de gíria rimada que é uma mistura de cockney (o modo de falar da classe operária britânica) com um vocabulário de repetições típico das crianças em fase de aprendizado da fala e um falar pseudo-elizabetano, o que o crítico Blake Morrinson chama, em seu prefácio para a edição de 1996 de Laranja Mecânica, de "inglês shakesperiano ou bíblico" (2004: XVI).

Burgess era admirador e foi profundamente influenciado por James Joyce. Suas investigações linguísticas colaboraram também para a criação das "elaboradas línguas pré-históricas faladas no filme 'A Guerra do Fogo', de Jean-Jacques Annaud (1981)" (ibidem: XI). Alguns vocábulos do nadsat: goloz (voz), rot (boca), yazik (língua) e zvuk (som, ruído) ${ }^{105}$.

\section{nonsense}

Sem sentido, desarrazoado, sem lógica. Para o dicionário Houaiss: "Frase, linguagem, dito, arrazoado [...] desprovido de significação ou coerência; absurdo, disparate [...] Filme ou escrito que recorre a elementos surreais, situações ilógicas, absurdas [...] Conduta contrária ao bom senso [...] de non 'não' + sense 'sentido, significação'" (2008: 2026). A definição que relaciona o filme ou escrito aborda um estilo peculiar em obras artísticas, cuja narrativa, a estrutura, os diálogos ou qualquer outro elemento faz criar uma outra lógica, alternativa às convenções, fazendo estranhar a percepção diante de um sentido que parece escapar. Para Deleuze "O não-senso não dá mais o sentido: ele devorou tudo" (2013: 85).

\footnotetext{
${ }^{105}$ Há um glossário nadsat que pode ser consultado nas edições brasileiras de 'Laranja Mecânica'.
} 


\section{psitacismo}

Silveira Bueno o define como "Papagaísmo, falatório, palavrório ôco, sem sentido nem nexo, cousa aprendida de cor e recitada sem a menor intervenção da inteligência, à maneira dos papagaios. Lat. psitacus, papagaio e suf. ismo" (1964: 3248), já o Houaiss traz "1perturbação psíquica que consiste em repetir palavras sem ter idéia do seu significado; 2 palavreado vazio e abundante; loquacidade; 3 - estudo por repetição mecânica; decoreba" (2008: 2328). A definição do Houaiss traz um recorte que aponta para a psiquiatria, "perturbação psíquica", que ao longo da história de seus registros nosográficos incluía alguns fenômenos patológicos relacionados a distúrbios psíquicos. Isso denota práticas glossolálicas em contextos psiquiátricos.

\section{salmodia}

De acordo com o Houaiss (2008), vem de salmo, cântico sagrado dos hebreus, que também é a maneira própria de cantar ou recitar em salmos. Ela guarda um poder mágico em sua enunciação, abrangendo os sentidos literal, alegórico-filosófico, hermenêutico e místico como aponta Alessandra Pozzo (2013). Como já comentado aqui, em Artaud há várias referências sobre a Cabala, desde princípios para uma respiração para a cena, como aspectos místicospoéticos sobre o poder do som através de uma palavra mágica. Para os hebreus a palavra criava realidades e a palavra primeira do criador era responsável pela realização e organização da existência na matéria. O poder de criação do Verbo ou Som primordial é elemento em muitas cosmogonias como é o caso do Gênesis bíblico e, em muitas liturgias, a recriação de aspectos do verbo divino é cantada.

A salmodia também é uma forma de melopeia, termo também definido nesse glossololalium, cujo o cantar é executado de forma monocórdia e relaciona-se à tradição da música sacra no contexto da liturgia judaico-cristã. As salmodias são compostas de fórmulas e divididas em: salmodia direta, salmodia antifonal e salmodia responsorial. Para Richard H. Hoppin (2002), na salmodia direta os versos dos salmos são cantados diretamente, do primeiro ao último, sem adição de outro texto; na salmodia antifonal supõem-se a alternância de semicoros, que cantam os versos do mesmo salmo, ou, como era o caso mais corrente, cantam um verso adicional adaptado a uma melodia livre e simples, uma antífona; e na salmodia responsorial um canto solo de um corista exige uma resposta do coro, o responsório, depois de cada verso. 
A salmodia, como melodia livre, desenvolveu-se significativamente na música medieval, no contexto do canto gregoriano ${ }^{106}$.

\section{supercazzola}

Termo italiano criado no filme 'Amici miei' (1975) ${ }^{107}$ de Mário Monicelli. Trata-se do discurso utilizado pelo personagem Ugo Tognazzi para confundir seus interlocutores. Um tipo de humor nonsense. A junção de partes de discursos diversos, sem ligação entre si, e a criação de palavras, criam uma confusão semântica no ouvinte. Soa como uma zombaria verbal, tirar sarro com a cara de alguém, uma prática iconoclasta, pois também é praticado para escarnecer uma autoridade. Não é exatamente falar sem dizer nada, mas antes, falar para confundir. A velocidade do falar também é característica desta prática, buscando dificultar o entendimento e a diferenciação de fonemas, palavras e frases. Não se trata, pois, de inventar línguas ou se apropriar da sonoridade de outras já existentes, mas de pura diversão em seu próprio idioma.

\section{trava-língua}

Trata-se de um jogo de palavras, cuja dificuldade está na velocidade e clareza de sua pronúncia. Parte da dificuldade está na quantidade de palavras a serem pronunciadas num curto tempo ou na sua articulação em virtude das diferenças fonéticas entre as sílabas. Diga o mais rápido que puder, no mínimo três vezes seguidas o trava-língua "toco preto, porco fresco, corpo crespo" ou "eu tagarelaria, tu tagarelarias, ele tagarelaria, nós tagarelaríamos, vós tagarelaríeis, eles tagarelariam". O aspecto lúdico gira em torno do ritmo e da sonoridade, elementos mais importantes que o significado da palavra. Os trava-línguas fazem parte da tradição oral popular, servem ao entretenimento e a princípios pedagógicos.

\section{xenolalia ou xenoglossia}

Para Houaiss (2008) ksénos vem do grego e significa estranho, estrangeiro, insólito. Já lalein, como já visto na etimologia da palavra glossolalia, significa língua. Falar (ou escrever, também compreender) uma linguagem estrangeira que não foi aprendida. Neste sentido, em muitos casos, pode ser muito difícil verificar, pois o conhecimento de tal linguagem pode ter sido adquirido na primeira infância, esquecido e mais tarde relembrado sem a consciência

\footnotetext{
${ }^{106}$ Para um estudo mais profundo ver 'La musica medieva'l de Richard H. Hoppin (2002).

${ }^{107}$ Lançado no Brasil com o título 'Meus Caros Amigos' pela Platina/Visocopy.
} 
explícita deste processo (este fenômeno é conhecido como criptomnésia) ${ }^{108}$. Na liturgia cristã é comumente referida como o dom de falar uma língua cujo falante a desconhece. É um termo do Novo Testamento, que é muito difundido nas igrejas católicas e pentecostais, sendo muito confundido com a própria glossolalia.

\section{zaoum}

Língua inventada por Velimir Khlébnikov, poeta vanguardista russo, em um conto de sua autoria chamado ' $K a$ '. A língua é a fonte de seu trabalho, pois embora ele se debruçasse sobre uma noção rítmica da linguagem, como termos criados por uma onomatopeia, por exemplo, eles relacionam-se semanticamente com outras palavras cujo aspecto é reconhecível. Neste sentido, os termos ganham significado numa intrincada relação semântica. O Zaoum é uma língua 'transmental' ou 'transracional', uma linguagem que transborda os limites da razão. A linguagem zaoum:

[...] desenvolveu-se naturalmente a partir de poucas unidades fundamentais do alfabeto, os sons das consoantes e das vogais eram as cordas deste brinquedo sonoro. E se tomarmos as combinações destes sons numa ordem livre, como por exemplo, em bobeóbi, então tais palavras, que não pertencem a nenhuma língua, dizem alguma coisa, algo de incompreensível, mas que existe, todavia... (Khlébnikov apud Bernardini, 1977: 64)

Pode-se fazer algumas relações entre Khlébnikov e Bely, mas uma diferença fundamental é que este não inventa, recria ou possibilita outra linguagem, mas propõem ouvir nos recursos da língua, nas palavras e nas letras, por exemplo, uma sonoridade primeva, um ritmo antigo sub-vertido na linguagem comum do nosso dia-a-dia. É como se seu poema sobre o som, 'Glossolalia', contasse a história de uma sonoridade anterior, na qual, de alguma forma, está embebida as línguas e palavras que conhecemos. Já Khlébnikov possibilita uma outra forma de compreender a semântica se apropriando dos ritmos e das sonoridades das letras e palavras. Há, neste caso, um jogo semântico, próprio das transgressões e investigações linguísticas do início do século XX.

${ }^{108}$ Livreto In 'Okkulte Stimmen - Mediale Musik', Berlim: Supposé, 2007. 
Ele pensava ter arquitetado um método para fazer sua boca dizer tudo o que quisesse. Queria dobrá-la, trabalhá-la, submetê-la todo dia ao treinamento respirado, torná-la firme, torná-la flexível, dar-lhe músculos pelo exercício perpétuo. Até que ela se transformasse numa boca sem fala, até falar uma língua sem boca... Como um bailarino que quisesse sempre dançar mais, dançar mais longe, dançar até o fim, até que não houvesse mais ninguém no espaço.

Valère Novarina

\section{qual a diferença entre mim?}

Um recorte cartográfico de um conjunto de práticas glossolálicas que não cessam de experimentar as possibilidades da voz. O koan agora se volta pra mim, é para as configurações de uma singularidade que ele se desdobra. São os meus outros que são cartografados, os meus pactos e alianças, fragmentos de uma legião. No entanto, as cartografias são sempre coletivas porque são políticas, agenciam muitos territórios e apontam sempre para uma alteridade, ainda que animal, magmática, mineral.

Como uma noção poético-conceitual veio agenciar a conveniência do meu devir glossolálico? Pois a glossolalia, enquanto um conceito espesso e aparentemente inapreensível diante de seus múltiplos contextos, parece querer fugir das formas, dos métodos, das normas, requisitando certa marginalidade. Mas aqui intenta-se tornar palpável algumas experiências dentro de um conjunto de práticas de uma voz que procura desarrazoar-se. Para isso recorro àquilo que parece dar presença ao som, a própria constituição dele, neste contexto, ao som da voz: seus parâmetros.

A apropriação dos parâmetros do som aqui pretendida é, antes de um território conceitual, um meio de análise do som, enquanto recurso para uma evidência poético-material das criações aqui investigadas. Recursos que servem ao método cartográfico. Busca-se dar alguma materialidade a elementos que podem ser mensuráveis tecnicamente, ainda que referências filosófico-poéticas perpassem toda a cartografia.

As criações aqui analisadas são vistas como blocos de devir e, embora façam parte de uma prática mais ampla, elas funcionam também com certa independência. Também não exploram todo o potencial do que pode uma noção de glossolalia para a voz em performance. Demais, são fragmentos de um conjunto de práticas de escuta, pois embora não tenha sido o foco dessa 
pesquisa, a escuta faz parte das muitas formas de se experimentar uma vocalidade glossolálica, não podendo ser separada do que poderia ser o devir de uma técnica para tal vocalidade.

Retornando ao 'entre mim' do koan, sou lançado nos territórios do que me é e como me é conveniente criar enquanto ator e performer. E criar requisita alianças e também aponta para limites singulares, demônios singulares, perguntas e respostas singulares. O que me espera? O que espero de mim? Retorno aqui às possibilidades do pacto com o diabo, zona indiscernível, cujos desejos procuram investir nas bordas, em micro-devires, na busca de uma voz possível em performance. O que faço agenciar numa possível glossolalia?

Um pacto com o diabo que dê vazão à voz em performance se configura num embate com limites e limiares, estratos e seguimentos. O que se pretende ao pactuar? Riobaldo, nas Veredas-Mortas, topos do pacto, remoía: "E, o que era que eu queria? Ah, acho que não queria mesmo nada, de tanto que eu só queria tudo. Uma coisa, a coisa, esta coisa: eu somente queria era - ficar sendo!" (Rosa, 2006: 384). Ficar sendo: uma desmedida? Ser mais que eu mesmo? Mais que algum estrato do que sou agora e parece querer me definir? Não seria sempre um limite possível, via de constante experimentação, devir? Aqui soa como uma necessidade vital, estar sendo enquanto se cria, buscando um risco que é um limite, procurando fazer alianças com figuras de borda, borda de si, no limiar dos vilarejos de si:

Os feiticeiros sempre tiveram a posição anômala, na fronteira dos campos ou dos bosques. Eles assombram as fronteiras. Eles se encontram na borda do vilarejo, ou entre dois vilarejos. O importante é sua afinidade com a aliança, com o pacto, que lhes dá um estatuto oposto ao da filiação. Com o anômalo, a relação é de aliança. O feiticeiro está numa relação de aliança com o demônio como potência do anômalo (Deleuze; Guattari, 2005: 28).

Esta política de agenciamentos com o diabo, enquanto potência feiticeira, para Deleuze e Guattari, procura escapar aos grandes estratos sociais. E como isso pode configurar-se numa performance vocal, sobretudo enquanto fenômeno glossolálico? Voltemos mais um pouco e pensemos na borda, no limite, no limiar, naquilo que Derrida chamou de limitrofia, "à experiência propriamente transgressal, se não transgressiva, de uma limitrofia" (2002: 57). Onde está o limite? Onde está a fronteira? Lá? Aqui? Espessa, heterogênea, já começa aqui a fronteira. Em certo sentido, eu possibilito o limite, pois torno-o espesso, diluo suas linhas, afeto as margens, bloqueio, deixo passar. 
E se a limitrofia seria "o que se avizinha dos limites mas também o que alimenta, se alimenta, se mantém, se cria e se educa, se cultiva nas margens do limite" (idem), o que procuro agenciar aí? Do que se alimenta meus limites? Nesse contexto para uma tal vocalidade em performance, o que procuro ultrapassar? O que procuro deixar passar? Quão denso é tal limite? É um limite porque é um bloqueio fisiológico? É um limite de gênero? É um limite moral, estético ou conceitual? "Que são as bordas de um limite que cresce e se multiplica em se nutrindo do insondável?" (ibidem: 60).

Há um temor que ronda a possibilidade do pacto. Muitas vezes o medo o impossibilita. Uma superdose de prudência: sinto de cá uma inquietude criativa, mas o limite parece abissal. O que se passa? "O que eu estava tendo era o medo que ele estava tendo de mim!" (Rosa, 2006: 383), exclama Riobaldo. O medo do medo do diabo. Um medo multiplicado nos dentros numa possibilidade de alteridade com os foras, reavaliação de limites e prudências. Limite de si numa relação afetiva com todo o cosmos. O que eu posso com a voz pode me aterrorizar? É motivo de vergonha? Soa ridículo? Parece anormal? Parece sujo? Neste sentido, eu também sou o limite, eu alimento esta limitrofia, eu sou a voz possível, eu sou o limite do possível. O pacto é comigo, é com um outro de mim e também com outros. Quando evoco o nome do diabo na encruzilhada, trata-se de um agenciamento coletivo de enunciação.

Uma experiência muitas vezes acontece porque pactuamos, pois também é uma permissão, podemos dar espessura ao limite. Às vezes o limite é inominável, as palavras não chegam até lá, ali as coisas embaçam, perdem as linhas, as formas. Para Derrida, a limitrofia não se trata somente "do que nasce e cresce no limite, ao redor do limite, mantendo-se pelo limite, mas do que alimenta o limite, gera-o, cria-o e o complica" (2002: 58). Este limite é uma multiplicidade. E uma criação numa tal vocalidade implica uma legião.

Riobaldo, mais uma vez, referindo-se ao Demo e à possibilidade de um pacto: "Ele não tinha carnes de comida da terra, não possuía sangue derramável. Viesse, viesse, vinha para me obedecer. Trato? Mas trato de iguais com iguais" (Rosa, 2006: 383), iguais com iguais aponta uma vaga em mim, assim como aponta uma multiplicidade compartilhada, orgânica, nãoorgânica, pois, de fato, o diabo não aparece para Riobaldo, mas uma transformação se configura nele, o diabo pode não ser palpável, mas as evidências do pacto se mostram, pois o mundo pareceu mudar diante da mudança de Riobaldo. O pacto faz-se vibrar pela existência. Desdobramento de um virtual, desdobramentos de inexistências e inexistir, no Grande Sertão 
de Rosa, é provocar a existência. O diabo existe por sua inexistência onipresente. De tanto que ele não existe, acaba existindo demais.

Quantas vezes na sala de ensaio, no espaço-tempo da experimentação, na entrega da investigação criativa, um limite se anuncia com uma espessura de preguiça, como uma falta de coragem, como um medo indescritível, ou mesmo, como uma impossibilidade declarada? E por que estas indagações aqui? Porque ao investir energia numa pesquisa sobre glossolalia a partir de Artaud, percebi o quanto uma noção de risco era bem mais que retórica para que eu pudesse tocar determinados limites do meu desejo: percebi que muitas vezes, se eu não procurasse gaguejar como um animal desconhecido, se eu não jogasse a técnica às favas para depois recobrá-la sobre a experiência, se eu não me submetesse aos riscos de um excesso de ridículo que parecia oco, despropositado e sem sentido algum, se eu não investisse numa desmedida, o animal não chegaria, a técnica estaria sempre aquém, a experiência seria só uma palavra, eu não gaguejaria, e sobretudo, eu não teria paz.

Eu e meus demônios, novamente legião, os súcubos e íncubos nas camadas de subjétil, os debaixos de muitos debaixos, aguardando acesso, pedindo passagem, fazendo passar ${ }^{109}$. Os limites não são homogêneos, redobram-se sobre si mesmos, estão sempre na iminência de uma aliança, e outra, e outra. O que acontece com meu corpo e minha voz quando me aproximo de limites? O que vou me tornando? O que vai se tornando complexo? O quê? Como? Eu me aproximando da linha de borda... É sempre um processo de desconhecimento? É um outro que se transfigura e se multiplica, espessando o limite, tornando-o dentro e fora de mim uma heterogênese? O corpo como limite, a voz como limite. Um eu que vacila na virtualidade dos pactos:

Tanto que o eu é apenas um limiar, uma porta, um devir entre duas multiplicidades. Cada multiplicidade é definida por uma borda funcionando como Anômalo; mas há uma enfiada de bordas, uma linha contínua de bordas (fibra), de acordo com a qual a multiplicidade muda. E a cada limiar ou porta, um novo pacto? Uma fibra vai de um homem a um animal, de um homem ou de um animal a moléculas, de moléculas a partículas, até o imperceptível. Toda fibra é fibra de Universo. Uma fibra de enfiada de

\footnotetext{
${ }^{109}$ Diabo, demônios, íncubus e súcubus, termos vez ou outra anunciados neste texto, não pretendem aqui uma genealogia destas entidades, tão pouco uma mitologia em torno delas, mas agenciam um plano conceitual em que o risco, o perigo, o medo e o desejo do ato criativo confluem para uma experimentação vital. Derrida (1995) fala do súcubus, o demônio que se deixa deitar sobre, que está embaixo e também do íncubus, o demônio que deita sobre. Ele procurou um diálogo desta terminologia com a noção de subjétil na obra de Artaud, que inclusive acreditava em magias e sortilégios em que demônios procuravam tomar posse de sua vida, parasitandoo energeticamente e impossibilitando sua criação.
} 
bordas constitui uma linha de fuga ou de desterritorialização (Deleuze e Guattari, 2005: 33).

Os autores de 'Mil Platôs' comentam a ausência de uma lógica pré-estabelecida diante de tal experimentação, diante do limiar de fazer pactos e constituir alianças. Neste caso, o 'desconhecimento' não é um acaso jogado à sorte, mas supõe uma afinidade com o outsider, uma predisposição ao insondável, uma intuição aguçada, uma inquietude para efetuar-se numa experiência-limite.

A voz comporta estratos, sejam culturais, de gênero, estéticos, éticos, e há sempre uma possibilidade de se investir um outro tipo de desejo sobre estes estratos. Nas possibilidades de uma voz moral, ética, civilizada, bela, limpa, clara, ponderada, moderada, seja lá o que contextualmente isso signifique, há o risco do ruído, da sujeira, do excesso, de algum animal que a espreita. No anômalo como fenômeno de borda, vislumbra-se uma voz sem categoria pré-definida, ainda que ela se defina ou se enquadre posteriormente para, depois, possibilitar outras alianças inusitadas, outras anomalias. Há limites vocais, sejam fisiológicos, sejam culturais, e entre os territórios que se perfazem, uma miríade de demônios assombram as bordas dos vilarejos da voz. Há uma cidadela-voz, cujo nascer do sol derrama sua luz sobre. Tal cidade está à beira de um abismo, sobre o qual projeta suas sombras. Há ruídos estranhos e alguma anomalia parece tragar a sanidade vocal, alguma poesia povoada de águas turvas e seres sem forma que se redobram sobre si mesmos, produzindo uma algaravia bizarra, e grasnidos de pássaros mortos estão na garganta, há sempre algo para se experimentar quando o desejo se investe em fenômenos de borda.

Tomemos a voz como produção subjetiva, cultural, atada ao conjunto de órgãos fonadores, aos tubos, ao ar que entra e sai, à articulação da boca, à língua, tudo isso ligado ou fomentado por uma organização linguística das palavras, que é uma organização política, a lógica da comunicação, os moralismos possíveis de uma comunicação, a ordem de um discurso, procedimentos tramados para se dizer algo, a lógica do sujeito e o poder da significação. Estes territórios existem e procuram uma estabilidade, uma organicidade na produção de contextos semióticos, no entanto, estes territórios não são inteiramente explorados, há uma pragmática, cuja vida escorre engendrando outras semióticas, possibilitando outras experiências. Há aquilo que transborda o território, aquilo que marulha seus limites e que povoa seus entres. É 
diante da possibilidade da fuga e das lacunas que a faz proliferar que Deleuze e Guattari propõem uma política para suplantar um conjunto de significâncias e subjetivações.

Dessubjetivar, dessignificar e também desarticular, são práticas possíveis? Uma glossolalia na voz faz vibrar este conjunto de práticas? Há perigo e risco sobretudo. O risco de criar uma máquina movida pelo desejo de vocalizar o que afronta o sentido e, ao mesmo tempo, nada dizer. O risco de significar mais que o esperado. O risco de cansar, de desistir... O fato é que experimentar assim impõe um não saber como princípio cruel de criação, ainda que um saber intuitivo, experiencial, tome forma. A glossolalia, vinculada aos parâmetros do som e a uma miríade de processos e elementos que fogem, violentam ou fazem estranhar alguma noção de voz, situa-se aqui como experimentação, devir político-poético, como um contínuo investigarse, uma obsessão como princípio. No desapego das familiaridades, suscitar alguma estranheza, possibilitar uma porosidade, uma abertura. E se uma voz soa excessiva, assim o faz por fazer ressoar uma medida contextual. Estranhar-se é uma experiência que muitas vezes parece corromper princípios, algo parece fora do lugar, deslocado, uma voz que corrompe normas, uma voz que não alcança sua função. Investir no estranho é abrir possibilidades e suscitar novas estranhezas. Experimentar, experimentar, experimentar: a trindade de uma vocalidade glossolálica, pois "a experimentação substitui toda interpretação da qual ela não tem mais necessidade" (Deleuze; Guattari, 1999: 25).

Diante das práticas para criar para si um corpo sem órgãos trata-se, na singularidade dos casos, em se definir aquilo que passa e aquilo que não passa, tão como o que faz passar e o que impede de passar, assim principiam Deleuze e Guattari. Ou seja, na experiência de fazer circular intensidades, perguntar-se sempre "O que povoa, o que passa e o que bloqueia? (ibidem: 13). A experiência aqui diz a si mesma, pois ela não parece querer produzir algo, ela é a própria criação, a própria experiência e a percepção vital desta experiência. É dessa forma que a diferença entre mim busca cartografias de uma singularidade, é o entre que marulha, que suscita a aliança, que alimenta uma limitrofia e, ao mesmo tempo, é uma coletividade que me atravessa, o discurso indireto livre e sua potência polifônica. Na conveniência do que procuro agenciar, na confluência de desejos e afetos, uma legião transita. Deixar a voz ser povoada por uma desrazão, permitir que ruídos incomuns passem, línguas inventadas, nãolínguas, rearranjar os parâmetros do som em misturas inusitadas, ser tomado por alguma estranheza. 
Há uma sedimentação histórica das vocalidades, vinculadas a contextos culturais. Trata-se de política, de poder, de afetos que permeiam a constituição social, os hábitos, a ruptura ou a negação destes hábitos também, subjetividades, enfim, construídas pelo trânsito de energias e pela criação de regimes semióticos. As diferenças que me povoam me colocam em embates, pois sou habituado e familiarizado com sistemas e programas. Sim, há lutas. Lutas que vão ao encontro de muitas sedimentações, lutas que investem um desejo de experienciar a voz. Estou na confluência dos lugares (locus) da voz, enquanto convenção, que na verdade não é um lugar, mas lugares que contextualmente perfazem territórios com suas regras de trânsito energético: a fonoaudiologia e a divisão dos órgãos, a etiqueta cuja assepsia procura tirar o emocional e qualquer possibilidade de desequilíbrio da voz, as retóricas em nome de deus, cujas táticas persuasivas seguem princípios codificados, a voz militar, a voz do professor, a constituição de um aparelho fonador assim ou assado, a boca assim, o diafragma, a respiração, a postura e o ritmo, a cadência, o bel canto, a gramática bem executada...

Formas de sedimentação, da constituição de estratos, aglomerações energético-conceitual, político-econômico-espiritual, zonas de conforto, zonas de poder em que algo se estabiliza, constitui-se, podendo normalizar-se, normatizar-se, padronizar-se, enfim. A padronização parece necessária para experiência humana. Ela dignifica saberes. No entanto, o caos soa como outra necessidade. Não o caos entendido como falta de sentido, perda da lógica, da sanidade, mas o caos, cuja dimensão aberta e experimental, possibilita experiências únicas, fomentando outras lógicas. Diante da necessidade dos territórios instaura-se uma necessidade vital de experimentação.

Soando como um limite da linguagem e do corpo, também um extravasamento destas instâncias, muitas vezes diluindo os significados numa substância sonoro-vocal, possibilitando espaços poéticos para enunciações, suscitando um retorno do som da voz à sua materialidade, a glossolalia requisita uma cartografia singular nas práticas do ator e do performer. Tateando impossibilidades, ininteligibilidades, obscuridades é que o desconhecido se faz presente numa prática glossolálica. 


\section{epifonia $^{110}$}

..., me parece um tanto estranho intitular-se Eu-Artaud.

Eu-Artaud - Não se trata de um título, trata-se de devir...

Outro de mim - Mas o Sr. não é Antonin Artaud!

EA - E não pretenderia jamais sê-lo! Artaud foi Artaud. Eu sou Eu. Artaud em mim diz respeito a mim e não a Artaud... Antropofagia.

OM - E o que dizer de Artaud? Qual a parte dele que cabe em você, Sr. Gil? Como ele pode estar em você?

EA - Costumam dizer que todos os mortos estão em nós, mas não é esta a questão... De qualquer forma, Artaud em mim é molecular, simplesmente sou outro por ter lido seus escritos com alguma intensidade no ato da leitura. E isso não me autoriza compreender Artaud... Trata-se de devir-poético.

$\mathrm{OM}$ - Logo o Sr. é tudo aquilo que leu posto diante do pronome Eu?

EA - O simplório é sempre inequívoco, ele não acompanha sutilezas, não acompanha demônios, não acompanha aquilo que não está dado e não pode ser escrito, não acompanha aquilo que somente pode ser vivido... Sou sim, aquilo transmutado depois da experiência de ter lido algo em tal e qual grau de intensidade que permitiu-me outrar-me. É vibração, ressoa, não posso passar impune...

OM - Sr. Gil, não é pretensioso arrogar-se Artaud em si? Pois, embora louco, foi considerado um gênio para a contemporaneidade e dizer-se Eu-Um gênio não soa surreal, descabido...

EA - Artaud está entre nós? Ele é só um cadáver enterrado? Seus livros são ele? Sua obra é parte dele? Há espasmos de uma vida nos seus escritos? Há eletricidade? Há algo que transcende letras impressas? Por que ler Artaud? Não quero ser rotulado como Artaud, não quero ser eletrocutado como Artaud, não quero ser viciado em ópio como Artaud, não me interessa ser Artaud, não me interessa ter compaixão, interpretar ou criticar Artaud,... Interessa-me sim, escutar aquela voz sob a linguagem, aquele grito sob, aquela inquietação que não deixa a vida passar sem que você seja afetado,... E talvez este grito seja meu grito, seja minha inquietação, seja minha voz, multiplicada numa possível agonia de Artaud, multiplicada em sua voz, pois uma coletividade me perpassa... E se minha experiência é molecular, talvez eu possa dizer: 'Um morto jaz em mim' e, de forma mais sensata, sóbria e lúcida, 'Um vivo jaz em mim', pois de alguma forma eu acolhi uma potência sugestiva, um rumor se fez ouvir... O devir dilui princípios identitários, pois se somos legião...

\footnotetext{
${ }^{110}$ Sugiro ouvir os arquivos de áudio 'epifonia' (https://www.youtube.com/watch?v=WiM5kWuqpu8) e 'blefarite' (https://www.youtube.com/watch?v=k5PoB3P3kIw) antes da leitura dessas sessões. Um bom fone de ouvido propiciará uma audição mais rica.
} 
OM - E onde o Sr. quer chegar com isso?

EA - Suspeito que não se chega a lugar nenhum com isso (Risos)...

OM - Acha realmente que este senso pretensamente poético lhe torna alguém digno, Sr. Gil? Não lhe passa pela cabeça que o Sr. pode não passar de um usurpador, de um repetidor de teorias, um interpretador qualquer?

EA - Não só passa pela minha cabeça como faz parte das minhas inquietações... Também penso nas ficções dentro das ficções, e acredito numa ficção que intensifica a vida, pois ela é real, é prática intensiva. Pensemos nas ficções de Artaud e nas sucessivas ficções sobre sua obra, sobre sua pessoa. Digo as narrativas, os discursos, as histórias que se propagam, as ressonâncias de uma crueldade que atravessa os tempos... Há muita dissimulação, muito blá blá blá, muito enunciado, há soberbas e idiossincrasias também nisso tudo, mas como toda heterogênese, você ocupa um lugar político com o seu discurso a partir do outro... É claro que corro o risco de uma apropriação, inclusive fascista (risos), como fizeram com Nietzsche!

OM - Não me diga que está recriando Artaud e que essa peripécia dignifica seu trabalho?

EA - Volto a dizer que a questão em si não é Artaud, pois de alguma forma ele é alguém que já passou por aqui, alguém que de alguma forma ainda vibra entre nós, alguém que ainda se faz escutar... é uma incubação nos nossos espíritos, uma potência engendrada, uma incandescência. Mas o que mais importa ainda é a primazia da alteridade, minha relação com o outro, o que inclui a minha covardia, meus medos, meus pretensos saberes, minha pretensa confiança... Não posso me arrogar de viver um corpo sem órgãos para a prática da voz em performance, sempre transcendendo os limites de uma produção vocal assim ou assada, tampouco vou dizer que a crueldade é um sentido plenamente absorvido na minha vida, e o que seria plenamente?...

$\mathrm{OM}-\mathrm{Bem}$ visto, Sr. Gil..

EA - Mas não posso abstrair o que me tornei a partir disso tudo. Dessa forma, tanto um sentido de crueldade quanto das práticas que envolvem criar um corpo sem órgãos estão, em alguma medida, presentes na minha existência, seja como criador, seja no sentido mais amplo de ser humano, que inclusive são dimensões inseparáveis na experiência de Artaud. É dessa forma que Eu-Artaud é um outro devorado, em alguma instância digerido.

$\mathrm{OM}-$ Sr. Gil...

Do grego epi, sobre + phainein, mostrar, aparecer + phoné, som: aquilo que se faz revelar pelo som da voz. Importante notar que na Grécia clássica "o vocábulo phoné se aplique tanto à voz humana e à animal quanto a qualquer outro som audível" (Cavarero, 2011: 34). Trata-se 
de um arquivo de áudio de 5'31", gravado e mixado em estúdio a partir de improvisos baseados numa vocalidade glossolálica.

Epifonia nasce do desejo de explorar a voz para a performance sem a palavra, baseando-se, sobretudo, no jogo do som e seus parâmetros. Se a palavra aparece, ela é inventada, imaginária, e não tem nenhum significado linguístico a priori. A criação do áudio serviu-se de improvisos temáticos como: línguas imaginárias, cantos em glossolalia, melopeias, gritos e gargalhadas, ruídos bucais e respirações. Estes improvisos foram práticas cotidianas investigadas no mês de junho de 2013, buscando a exploração de nuances do som da voz. Às vezes me debruçava sobre o que parecia uma língua mais consonantal, outras vezes vocálica, ou ainda sobre um motivo musical com ênfase no ritmo, às vezes na melodia, procurava ainda povoar a voz de ruídos, investia em timbres, sons miúdos, sons cheios e vigorosos... Depois permiti-me experimentar os improvisos livremente em estúdio e após um bom material gravado, disponível em arquivos digitais, investi sobre as possibilidades de uma organização dramatúrgica $^{111}$.

A dramaturgia seguiu princípios do recorte, colagem e sobreposição com progressão temporal, no que pode ser visto como uma narrativa sonoro-poética. $\mathrm{O}$ áudio buscou valorizar a voz do performer se abstendo o máximo possível de intervenções eletrônicas para modificar a captação original. Procurando suscitar potências imagéticas a partir da dimensão acústica da voz, epifonia se abstém do recurso verbal e investe na multiplicação de sentidos do som a partir da experiência na escuta.

Tanto no trabalho escrito como nos exercícios práticos aqui analisados intenta-se certa estranheza no ritmo, mesmo uma arritmia enquanto proposta formal. Às vezes uma aleatoriedade dos acentos, outras uma precisão insensata deles. Essa noção rítmica vai ao encontro da síncope, que aqui busca transcender seu sentido matematicamente musical, se apropriando de valores poéticos e filosóficos. Synkopè, do grego, relaciona-se a uma supressão ou corte, o que faz mudar a cadência rítmica na música, o ritmo cardíaco na

\footnotetext{
${ }^{111}$ O arquivo foi gravado e editado no estúdio particular do produtor Jota Dale em julho de 2013. Participei de todo o processo com o apoio técnico de Marcus Ferreira. O Áudio foi captado em um microfone AKG modelo C414 XL II, passando por um pré amplificador valvulado Universal Audio, modelo 2-610, e convertido para áudio digital por uma interface Focusrite modelo Saffire Pro 40. A gravação desse áudio digital foi feita em uma DAW (Digital Audio Interface) Avid modelo Pro Tools 9HD. Foram gravados 22 canais de áudio, e a manipulação do áudio foi feita no Pro Tools, utilizando os seguintes plugins: Digidesign - Signal Generator; Waves - Phaser; Waves - RVerb; AIR - Dynamic Delay; Digidesign - EQ7 Band. Os áudios foram mixados em um par de monitores KRK Rokit5, e em fones de referência Beyerdynamic DT 880.
} 
medicina, ou mesmo o ritmo ao se dizer uma palavra na linguística. Este corte faz mudar o pulso e desestabiliza um contexto, o que era pra ser previsível, torna-se uma surpresa. Um deslocamento de sentido, a supressão dele, um corte abrupto. É dessa forma que epifonia procura explorar sua progressão temporal, meio ao acaso, de maneira incerta, como alguém que se deixa rumar a esmo. O princípio da aleatoriedade embrenhado na síncope.

Nos contextos em que foi apresentada ${ }^{112}$, epifonia tinha uma estrutura de looping, não tinha início nem fim, de forma que seus motivos sonoros se redimensionavam num eterno retorno. Isso corrobora com alguns princípios do arquivo de áudio de 5'31"113, cuja cartografia provisória pode ser observada na página seguinte. Vários elementos sonoros retornam em outro momento da escuta, recontextualizando-se dentro da própria duração do arquivo, como é o caso da gargalhada, de cor amarela na imagem, que inicia o áudio e retorna em 54", 2'53" e, por fim, em 5'; tão como o que pode parecer uma prece-súplica-desespero cujo clichêe $\hat{e}^{114}$ supõe uma voz feminina, identificada na imagem com a cor verde, e que se inicia em 2'57" e é retomada em 4'30". Os retornos são núcleos que se desdobram em mutações no tempo e na percepção, ao infinito. Um eterno déjà future.

Sua imagem cartográfica é aberta, perpassada pelos conceitos que motivaram sua criação, como é o caso de uma filosofia do desejo, uma noção de corpo sem órgãos e de subjétil, uma limitrofia, glossolalias... Como pode ser observado na figura, não se trata de fidelidade matemática ou de uma partitura no sentido estrito do termo. Trata-se antes de um amálgama de elementos que parecem díspares, mas que configuram maior organicidade aos princípios do áudio. A linha magenta que espirala é a progressão temporal de 5'31". No entanto, percebese que há um tempo que a antecede e um tempo que a ultrapassa, marcado pela continuidade e

\footnotetext{
${ }^{112}$ Surgiu como um exercício da disciplina 'Tópicos em Poéticas Contemporâneas 1' do mestrado do PPG-Artes UnB, sob orientação da prof ${ }^{a}$ Karina Dias, para a ocupação e exposição 'Linha Tênue' em julho/2013, na Galeria Espaço Piloto da UnB, Campus Darcy Ribeiro. Também foi apresentada no 'VIII Mexido de Dança' em novembro/2013 no Anfiteatro 9 da UnB, Campus Darcy Ribeiro e no 'III Seminário a Voz e a Cena' realizado em novembro/2013 no CEN-UnB, Campus Darcy Ribeiro.

${ }^{113}$ Para a reprodução do arquivo de áudio, nos contextos em que foi apresentado, utilizou-se dois gravadores/reprodutores 'H4n Handy Recorder, Zoom' e dois headphones 'Bose SoundTrue'. A audição do arquivo consistia numa experiência individual, em que o ouvinte sentava-se numa cadeira voltada para uma parede, de preferência com os olhos fechados/vendados, com o fim de evidenciar tal experiência por meio do som.

${ }^{114} \mathrm{O}$ uso recorrente da palavra clichê nesse texto não procura atribuir um juízo de valor a ela no contexto dessa pesquisa. Inclusive, trata-se muitas vezes de uma aproximação ao clichê que de um clichê propriamente dito. A despeito dele ser uma ideia desgastada por seu uso frequente, o que importa algo dado e batido, aqui, ele tem valor ou sentido de acordo com o seu contexto, de onde infere-se que, por si só, não é bom ou ruim. Demais, o uso singular de um clichê importa uma reconfiguração na apreensão e produção de sentido a partir da dimensão acústica da voz aqui tratada.
} 


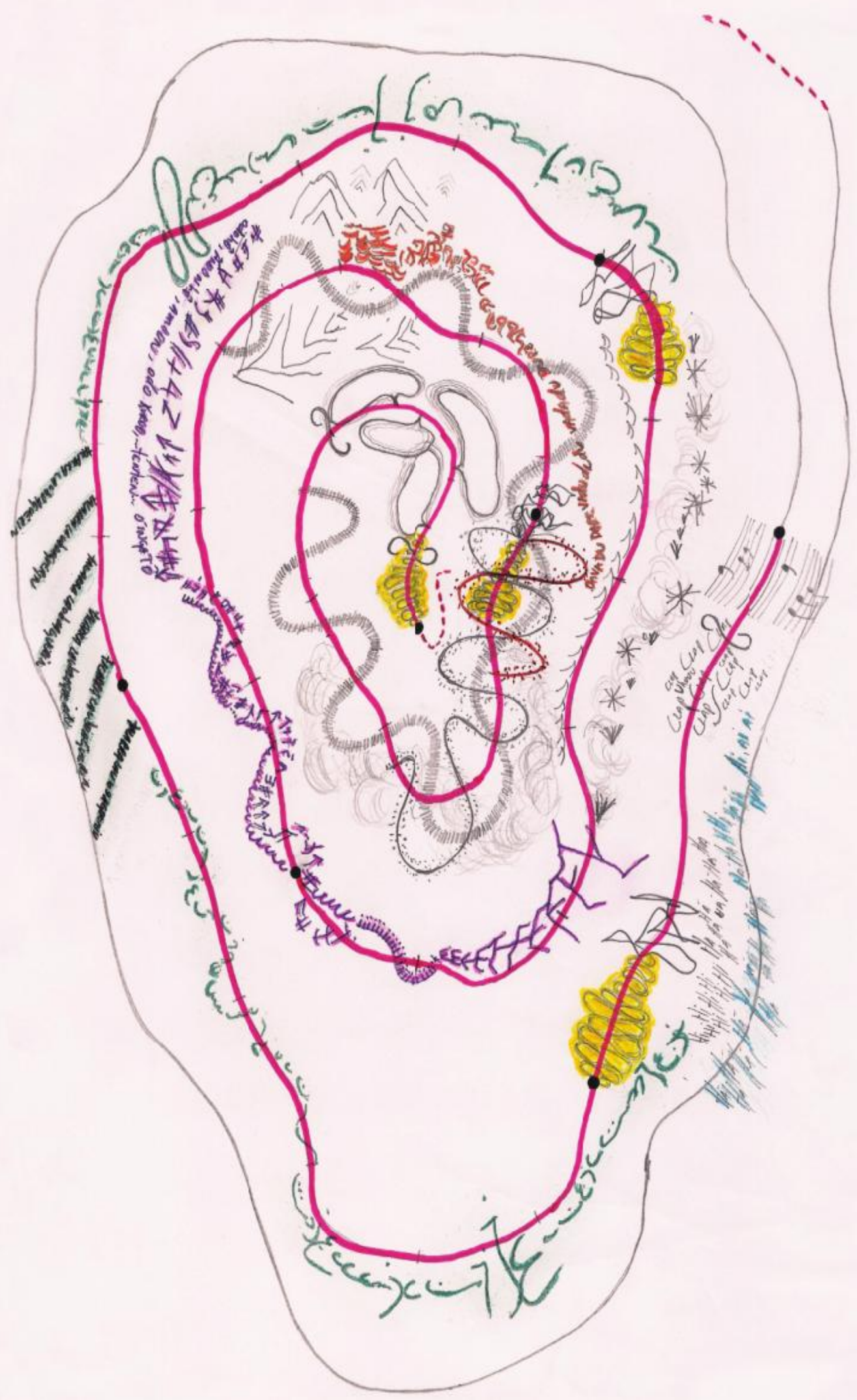


pelo tracejado também magenta de uma linha que supõe-se virtual. Um looping espiralado que agrega a característica de elementos que retornam e se reconfiguram no tempo. Epifonia parece suscitar um espaço ambíguo e flutuante, e um tempo que parece suspenso à entrega das experimentações vocais. Pretensamente, deveria agregar valores moleculares de uma criação afetiva, de um desejo de escavação pessoal. Também é recorte, parte de um processo, fragmentos de uma multiplicidade vocal. Daí, o contorno provisório de uma cartografia que parece viva.

Assim como epifonia parece evocar sentidos ambíguos, incertos e fugazes, sua cartografia sugere uma molecularidade que lembra um corte transversal de uma célula, mesmo um útero em expansão, assim como uma espiral galáctica. Uma orelha em espiral, a vertigem de uma voz que vaga a esmo e uma escuta que acompanha seu delírio. Sem fim nem começo, sugere um corte da espiral, que segue para aquém e além de si. Seu recorte temporal é torto, não linear, apresentando ilusões de escuta, pois os blocos de tempo, marcados pelos pontos negros, não são simétricos e proporcionais. Acompanham as impressões afetivas em relação à percepção do áudio, que segue numa imprecisão rítmica, movediça, jogando com a aleatoriedade e a instabilidade. Agrega sinais que sugerem simulacros de línguas como o japonês (1'24" a 2'25") e o árabe (2'57" a 5'04"), em roxo e verde respectivamente na imagem, também um conjunto de clichês alegóricos, como a sinuosidade de uma onda grave (24" a 1'30"), os balões de falas das histórias em quadrinhos (7" a 20"), a onomatopeia de aplausos ressoando (5'19" a 5'25"), o pentagrama musical (5'26" a 5'30"), entre outros elementos que parecem invadir uma cartografia celular. Assim como uma noção de glossolalia, aqui sugerida, os motivos cartográficos apontam citações de diversos contextos, que inclui a linguagem, signos, clichês, contornos atômicos e galácticos.

A despeito de sua apresentação num plano bidimensional, ela sugere também uma imagem em três dimensões, como os volteios de uma molécula, o serpentear da via láctea, a profundidade de uma orelha, as topologias de um útero estilizado. Se pensarmos no aquém do que requisita suas formas, podemos imaginar uma experimentação da voz em duas dimensões e mesmo numa dimensão, e no seu além, podemos inferir uma quarta dimensão, que parece apontar para uma experiência descabida de uma vocalidade. Um devir sonoro parece confluir numa espiral que arrasta uma miríade de elementos audíveis, rumo a uma escuta vertiginosa. 
Retomando ao arquivo de áudio, o que fora produzido na liberdade do improviso sem um sentido pré determinado, no puro desejo de deixar tatear um delírio, sofre uma operação coercitiva no processo de dramaturgia. Ao mesmo tempo, essa operação também faz jogar o som em sua cirurgia de cortes, sobreposições, justaposições e repetições. Epifonia é cheia de vazios ou pausas ou silêncios ${ }^{115}$. Aí está a brecha, o entre da imaginação, de onde os sons parecem nascer e pra onde eles parecem sumir ou fugir. Isto também é cíclico, uma supressão como na síncope, também uma abertura.

O fato de epifonia ser tão repleta de silêncios vai ao encontro de sua estrutura e de sua própria etimologia, pois trata-se de aparições, erupções, de vozes que surgem, mostram-se sozinhas e transformam-se em outras vozes. Há o tempo do solo, da singularidade de dizer-se a si mesma, de dizer-se na ficção de si mesma, num simulacro de uma língua, de desarrazoar-se enquanto som. Ao passo que as sobreposições situam-se pontualmente na passagem de uma coisa à outra, como comentários ou um agenciamento que, contextualizando uma voz, a faz fugir para aparecer noutro contexto. Uma voz está sempre fugindo para outro território, está sempre em vias de ser outra coisa. Está sempre devindo numa cadeia de acontecimentos que poderia seguir para sempre os delírios de um desejo irrefreável. Um recorte de um discurso indireto livre constante, que se recria e se multiplica no espaço-tempo, aquilo que se aproxima do que Certeau (2011) chamou de ruídos de corpos e citação de vozes. O recorte soa como a apropriação de sons de diferentes contextos.

Epifonia é fundamentalmente som, pois desenvolve a produção e percepção de sentidos a partir de uma dimensão acústica, o que implica sua relação inevitável com os parâmetros do som, cujos aspectos constituem qualquer sonoridade existente. Diferente do entendimento da Acústica que, isolando a onda sonora de qualquer contexto da experiência humana, relaciona a frequência, a intensidade e a duração enquanto parâmetros do som, ou mesmo a Música, que ainda inclui o timbre, a noção aqui apropriada também considera o ritmo, que inclui a duração, o contorno, a direcionalidade, a reverberação, o ruído e o silêncio como características fundamentais dos sons. Esta perspectiva é defendida por César Lignelli 2014) ${ }^{116}$ ao priorizar o

\footnotetext{
${ }^{115}$ Para Lignelli (2014), o silêncio soa aqui como um parâmetro cuja relatividade relaciona-se às convenções culturais e à percepção dos sons. Ou seja, ele não é um valor absoluto, logo não se estabelece somente por uma ausência de som, mas configura-se como algo indistinto que se faz soar ou não de acordo com sua apreensão pela percepção humana.

${ }^{116}$ In Sons E(m) Cenas - Parâmetros do som.
} 
referencial humano na percepção do som e não seu isolamento físico, o que agrega valor ao contexto da performance aqui tratado.

A escolha por uma análise baseada nos parâmetros do som também se relaciona ao fato de que, em muitos contextos, a glossolalia aspira à produção de som, antes mesmo da produção de sentido semântico, como a palavra. A palpabilidade do som vocal tem densidade, volume, forma e propicia sentidos independente de seu caráter linguístico. A glossolalia tem sua evidência na matéria do som enquanto agenciamento de seus parâmetros e é a partir disso que ela possibilita espaços de enunciação. Aqui faz reverberar uma materialidade pretendida por Artaud numa apropriação singular da constituição do som da voz. Além disso, o termo 'análise' não intenta, aqui, pormenorizar a experiência a ponto de dar conta de tudo aquilo que ela faz sugerir, mas procura-se pontuar aspectos que podem ser desdobrados, imaginados e praticados, de forma a suscitar outras cartografias.

A despeito de epifonia parecer ser isto ou aquilo, de alguns trechos apontarem para determinadas representações e de, inclusive serem usados termos de cunho pedagógico que limitam seus sentidos, ela, de fato, não diz nada, ao menos não procura dizer nada num sentido linguístico, antes disso, diz enquanto matéria do som. Algo revolve entre o que parece ser e o milagre da multiplicação. Dramaturgicamente, segue princípios sonoros que por aproximação pedem um timbre depois de outro, uma intensidade depois de um trecho ruidoso, um ritmo que se alia a quebras numa noção de síncope, ou mesmo numa aproximação com o timbre, um contorno aliado ao trabalho das frequências, à intensidade aliada à uma dinâmica. Antes de pensar que algo está sendo dito, algo está dizendo-se, ou experimentando-se o que é ser voz ${ }^{117}$.

\footnotetext{
${ }^{117}$ Lignelli (2014) discorre sobre os parâmetros do som contextualizando uma pragmática no contexto da performance, dessa forma, uma breve definição de alguns deles servirá de base para as análises de epifonia e blefarite. Para ele, a intensidade relaciona-se ao grau de energia da fonte sonora, o que implica dizer que quanto mais forte um som maior sua intensidade. A frequência, por uma convenção cultural, associa-se à altura de um som, ou seja, quanto mais alto, mais agudo e, quanto mais baixo, mais grave. Interessante notar a relatividade, apontada pelo autor, na independência desses dois parâmetros na percepção humana, pois comumente, quando há um aumento de frequência, tende-se a perceber um som mais agudo como sendo mais intenso, ainda que se mantenha sua intensidade. Isto será observado em alguns trechos de blefarite, por exemplo. Já o timbre, singulariza a qualidade de determinado som de acordo com um conjunto complexo de elementos que vão desde a densidade material da fonte sonora à distribuição das frequências num conjunto de harmônicos e ao ataque e seu fluxo, que é a maneira como o som se modifica depois de emitido. É comum o uso de adjetivos para se referir aos timbres, como é o caso de uma voz metálica, aerada, escura, pequena, rasgada. Lignelli pontua o caráter de afecção pertinente ao timbre na sua relação com a dimensão acústica, ou seja, a percepção tímbrica tem um importante papel afetivo na relação com o som. O contorno, para o autor, "remete ao delineamento de uma melodia, levando em conta exclusivamente o padrão relacionado às frequências" (2014: 223), o que
} 
Certamente, o 'parecer ser' relaciona-se à miríade de sentidos possíveis numa dramaturgia conveniente ao ouvinte, o que de maneira geral implica dizer que uma coisa pode ser várias coisas de acordo com a percepção e experiência de quem ouve. Mas estamos falando de uma prática glossolálica, que muitas vezes diz algo sem nada dizer, o que importa reconsiderar os processos de busca de sentido, sobretudo porque como apontam várias histórias das glossolalias, em muitos contextos, elas precisam significar algo, precisam de um sentido que dê alguma segurança, como na psicanálise, na igreja, na linguística, na psiquiatria. No entanto, vislumbra-se aqui, uma possibilidade da experiência de uma incompreensão genuína. A despeito de uma elaboração estética, ou da lógica implícita na produção de processos inconscientes de um louco, mesmo das regras litúrgicas da comunicação de uma voz divina, ou ainda de um vaticínio oracular, existe a possibilidade de um koan irredutível, a experiência primeira de vocalizar algo e de escutar esse algo na figura do performer e uma experiência desarrazoada de quem ouve. Logo, a experiência de uma incompreensão genuína relaciona-se à entrega à uma abstração sonora que, neste contexto, apoia-se em contornos que apontam para algo que vislumbra ser reconhecível, mas que não se define: um simulacro. Ou, simplesmente, um desarrazoar diante do desconhecido.

Epifonia é uma peça para ouvir? É um trecho de uma radiofonia? Tem personagens? Conta uma história? Parecem personagens de desenho animado. Não sei se entendi bem! Essas são algumas frases que ouvi de pessoas que ouviram o áudio. Isso denota uma singularidade de sua sonoridade que, explorando variações de timbre e frequência, faz vislumbrar imagens de personagens e contextos de uma representação humana. $\mathrm{O}$ arquivo abre com uma gargalhada, que é interrompida por um pedido de silêncio, que é seguido por um burburinho, que é interrompido por novo pedido de silêncio e, ao longo da audição em looping, a busca pelo sentido apoia-se num conjunto de parâmetros que parecem contar algo. No entanto, é fundamental a experiência do simulacro, ele simplesmente é verdadeiro enquanto simulacro e sua ficção é real. Um bloco de devir é expresso e manifesta-se. Trata-se da voz de um performer experimentando sonoridades. Agregar determinados valores emocionais, psicológicos, representativos ou não, diz respeito, sobretudo, à experiência de quem escuta.

convencionou-se chamar de contorno melódico na música, no entanto, pode-se inferir contornos que são delineados por outros parâmetros como o ritmo ou mesmo o timbre. Demais, cabe falar sobre a dinâmica, que relaciona-se às mudanças de intensidades num contexto sonoro. Vale lembrar que a dinâmica não é um parâmetro do som, mas intenta delinear, de acordo com o autor, "uma espécie de 'relevo ou mapa do fluxo sonoro'" (ibidem: 184). 
Ao mesmo tempo em que o simulacro é real em relação a uma língua natural, por exemplo, algo acontece que não simula nada, que é o próprio experimentar-se enquanto ruído do corpo: uma voz que é som produzida por uma singularidade, possibilitando espaços para que todo som possível na voz possa passar. Ou seja, ao tatear a experiência de enunciar sons, o performer não simula, ele simplesmente experimenta. Ouçamos a voz que se inicia em 2'57", cujo devir é representado pelo contorno verde na cartografia, que parece uma espécie de lamúria, perpassada por certa angústia e desespero, numa voz cujo clichê aponta para o gênero feminino. Estes adjetivos parecem carregar os afetos emanados pelo timbre metálico, tão como pela variação de frequências, cujas notas mais agudas, agregadas ao timbre, apontam uma ideia de desespero. Em torno de 3'30" essa voz sofre uma metamorfose, transforma-se numa voz pequena, vacilante, quase sussurrada, mais estável em termos de frequências, evoluindo para uma fórmula entoada em 3'43", que é repetida por 6 vezes. Depois disso, ela soa numa mistura de voz falada com resquícios da melodia da fórmula, a voz parece ficar menor ainda, perdendo-se em seus murmúrios entrecortados, numa estabilidade frequencial, micro-sussurros e silêncios. Desse território de sons miúdos, retorna a voz do princípio da metamorfose, que parece suplicar em desespero, novamente o retorno cíclico de uma voz que desdobra-se sobre si mesma.

Todos esses valores, que podem ser vislumbrados nesse devir vocal, são delineados pelos parâmetros, cujo contorno, por exemplo, perfaz uma imagem geral que contextualiza os territórios por meio das frequências, e cuja dinâmica das intensidades aponta para um percurso, cujo fluxo implica um mapeamento sonoro. Da mesma forma, o timbre agrega um valor afetivo com elementos que dão certa identidade à fonte sonora. Percebe-se a confluência de vários parâmetros para uma imersão no som, o que implica notar um conjunto de estímulos na matéria vocal, que procura agenciar o sensorial por meio de processos sinestésicos: um contorno que suscita silhuetas, formas e imagens ou um timbre que suscita uma emoção ou mesmo qualidades como cores e texturas.

Como se delineia o contorno em epifonia? O contorno compreende uma noção formal do todo pela recorrência de padrões que podem ser abstraídos em relação a um ou mais parâmetros. No entanto, como foi comentado aqui, é comum relacionar o contorno à progressão de frequências no tempo, como é o caso do contorno melódico, que é mais claro em blefarite, por exemplo. Mas pode-se inferir contornos a partir de uma dinâmica tímbrica ou rítmica também. Ou seja, o comportamento de um ou mais parâmetros podem delinear características de uma 
voz, seu lugar no espaço e no tempo, de forma a se perceber desenhos sonoros que apontam para formas peculiares. Pode-se perceber um grito e formas peculiares desse grito, por exemplo, em relação a um conjunto de valores acústicos que podem ser abstraídos do seu som, seja pela quantidade de ruídos do som emitido, seja pelo seu conjunto de frequências, ou mesmo pelo timbre.

Em alguns exercícios de grammelot ou gibberish, por exemplo, pode-se perceber uma forma espanhola, alemã ou japonesa de se falar pela apreensão e produção de sentidos relacionados aos acentos rítmicos das palavras e frases, assim como pelo conjunto de frequências nelas empregadas e sua entoação, e mesmo pelo timbre usado, o que perfaz uma espécie de paródia sonora. Dessa forma, estou falando de clichês, como é o caso da língua portuguesa falada no Brasil, cuja recorrência de vogais, por exemplo, faz soar uma melodia diferente da de Portugal, que parece aglomerar consoantes, subtraindo-se as vogais em várias palavras. Ou mesmo, a quantidade de consoantes presentes na estrutura da língua alemã, o ' $h$ ' aspirado como o 'r' e o acento mais abrupto, que a qualificaria como uma língua mais dura e áspera que o espanhol. Tratam-se de valores relativos, no entanto, é possível perceber, por meio da utilização dos parâmetros do som, um acento inglês muito diferente do italiano, por exemplo, evidenciado na voz de Dario Fo numa performance de grommelot $^{118}$. Trata-se da ideia genérica e clichê da sonoridade de uma determinada língua. Dessa perspectiva, as línguas são contextos musicais e, sobretudo, sonoros. Territórios de desejos acústicos e performáticos.

As algaravias que se depreendem de epifonia perfazem um conjunto de contornos que podem ser abstraídos de seus fragmentos como também apontam uma noção de todo. A respiração que se inicia em 33" do áudio, é inferida pelo conjunto de altas frequências emitidas pela passagem do ar pelas vias respiratórias, tão como por uma percepção tímbrica aerada. Demais, percebe-se, pelos mesmos motivos, que a respiração é feita pela boca e não pelo nariz, pois pode-se ouvir e perceber os movimentos da boca na mudança de som. Uma simples gargalhada supõe um desenho, uma imagem que é delineada por alguns parâmetros perfazendo um contorno: ritmo, frequência e timbre. Ouça a gargalhada, em azul na cartografia, que se inicia em 5'02" e termina em 5'21". Ou seja, trata-se de fato de uma gargalhada cujo contorno é perceptível em relação ao ritmo entrecortado, que lhe caracteriza como tal, numa impressão de sons curtos em staccato, tão como à progressão das frequências

\footnotetext{
${ }^{118} \mathrm{https}: / /$ www. youtube.com/watch?v=8A4n9Ez9O8g.
} 
que vão aumentando, dando a impressão de uma gargalhada jubilosa, sobretudo pelo fim, cujo "ai, ai, ai" denota uma satisfação depois de uma explosão prazerosa. Temos o contorno geral de uma gargalhada em que se pode perceber características como masculina ou jubilosa por meio de outros parâmetros.

Já falamos sobre as variações de timbre e frequência que denotam contextos representativos e perfazem imagens, que muitas vezes parecem desenhos de estruturas dramáticas. Isso corrobora com o contorno, seja ele melódico, tímbrico ou ainda rítmico, que constitui-se sempre na relação com outro parâmetro. No caso de epifonia, o contorno faz evocar a ideia de contextos que perfazem a experiência humana de acordo com o comportamento dos timbres e das frequências, como é o caso de uma suposta peça de teatro para ser ouvida, o que aparenta ser uma miríade de personagens que aparecem e retornam com o tempo, um contexto de dor e desespero, uma liturgia em melopeia, um pedido de silêncio, uma língua com resquícios de árabe ou japonês...

Ouçamos a voz que se inicia em 1'24", depois de uma explosão ruidosa de gritos, sons aerados e uma voz que entrou em convulsão, e termina em 2'25", designada na imagem cartográfica na cor roxa. Esta voz atravessa uma significativa mudança de intensidade e, sobretudo, de frequência, em seu devir, já que ao surgir, depois de uma pequena pausa, soa suave, pequena, comedida e aguda comparada ao seu término. Chamarei esta voz, para fins didáticos, de japonesinha, pois alguns elementos de sua articulação, dos acentos e do conjunto sonoro dos primeiros segundos, trazem alguns vestígios de um clichê do falar japonês. Ouçamos o devir de japonesinha.

Japonesinha é experimentação e anuncia-se numa linguagem desconhecida, sua primeira palavra ou frase (algo como 'odohô', tendo o "h" o som de "r"), parece ser falada, sobretudo porque a sonoridade que se segue aponta para um contorno melódico que, entre outras possibilidades, poderia ser uma cantiga cerimonial numa fala cantada. Alguns de seus trechos soam como um misto de melopeia e fala, murmúrios vocálicos, momentos em boca chiusa, progredindo para um timbre mais aerado e uma frequência mais grave. A princípio, sugere um timbre mais nasalado, com frequências mais agudas para uma voz masculina, no entanto não é inteiramente feminina, pois traz alguns traços de criança, o que a torna híbrida e embaçada quanto aos seus limites de gênero, sobretudo porque no final do trecho o registro está numa região, cuja frequência, dificilmente seria a de uma voz feminina. Ao mesmo tempo, esses 
valores soam relativos e acabam por revelar algumas expectativas vinculadas a clichês vocais. Japonesinha ressoa-se melodicamente escura, tendendo para uma escala menor, o que é inferido pelo intervalo entre as notas (variação das frequências) e, neste caso, pela dinâmica rítmica, que explora um fluxo mais lento. Japonesinha parece murmurar, às vezes insinua-se como um pequeno choro pelo entrecortar da sonoridade na busca por respirações curtas. Vai se transformando cada vez mais em melodia, entrecortando-se de pequenas falas, evoluindo para vocalizes com a letra 'u', depois 'i' e, por fim 'e'.

A variação das frequências aponta para o contorno possível de uma cantiga chorosa, numa escala menor, introspectiva e meditada. Japonesinha vai ficando mais grave, há uma progressão descendente das frequências, vai ficando mais suja, aerada. Os ruídos vão povoando-a, parece diluir-se em sua entrega resignada a um baixo ruidoso e volumoso. Japonesinha parece diluir-se na vogal 'e' grave, aerada, mais intensa, ao se desfazer num último sopro. Para o performer soa como uma liturgia na experimentação de alguns parâmetros (silêncio, timbre, frequência, intensidade, ruído, contorno), pois sua voz não perde a busca por uma variação contínua. Tal voz não sustenta uma identidade e, a despeito dos clichês e designações, ela não tem gênero, não tem território fixo, ela sugere uma desarticulação que se processa ao tatear a experiência de estar produzindo som.

Faço aqui um retorno ao silêncio em epifonia, pois no princípio era o silêncio, do silêncio nasceram as coisas e, para o silêncio elas parecem retornar. Quase uma ode às cosmogonias. Epifonia é configurada na pausa, no vazio, num silêncio conceitual. Seu ritmo é composto de vagas e aberturas. Em torno de vazios, outros parâmetros parecem ressoar e se agregar. Assim como o princípio do áudio, o fim dele pede um silêncio, requisita uma escuta. Soa como uma nota sempre onipresente, ao menos como uma evidência filosófica. Está entre as coisas.

O silêncio não só se faz soar como ele possibilita que algo soe. Em epifonia, as vozes parecem embrenhadas num vazio amorfo que a tudo permeia, pois mesmo quando uma voz soa, a exemplo de japonesinha, ela parece estar envolta em silêncio, o que dá a impressão de um espaço indeterminado, de um tempo suspenso. Qual o espaço-tempo de tais enunciações? Os sons parecem se perder nas brumas desse silêncio, que agrega um valor sonoro relativo à conveniência de contextos. O tempo da espera em epifonia faz soar o silêncio, assim como o tempo das mutações também o requisita. Uma voz está sempre devindo num espaço em branco. 
Dessa forma, o silêncio como parâmetro do som, se faz numa dinâmica peculiar na relação com os ruídos e vozes que parecem vagar em epifonia. Perfaz também uma noção rítmica baseada na pausa. Por isso, o áudio é tão repleto de vazios, como se algo estivesse sempre a ser engendrado do nada, em função do nada. As vozes também soam silenciosas, por vezes, por estarem sozinhas, é como um zoom requisitando uma escuta mais sofisticada, uma escutaminúcia, como um espectro glossolálico fugidio. Japonesinha nasce como uma voz pequena, murmurante, silenciosa, procurando fazer-se ouvir depois que uma outra voz entrou em colapso numa algaravia de gritos. Em muitos contextos da vida, uma voz como japonesinha poderia muito bem nem ser escutada, ela requisita a sutileza da atenção de uma voz que, a princípio, parece ensimesmar-se e, somente processualmente percebe-se sua mutação no tempo.

Quando digo que o silêncio agrega um valor rítmico ao áudio, não estou falando de um tempo determinado e um pulso constante como acontece em um plano de blefarite, mas sim de um ritmo esparso, de uma arritmia, de uma matéria sonora que se coagula aqui, estende-se ali, estabiliza-se assim. Num espaço aberto que parece atemporal, cria-se o próprio tempo no devir vocal.

Ao falar do tempo de cada voz e da singularidade dos fragmentos de vozes e a despeito dos cortes, colagens e sobreposições, há de se pensar numa voz, a voz do performer e sua singularidade, de tal forma que todo o áudio é uma mutação desta voz, é uma glossolalia que faz a voz desarrazoar-se como o discurso indireto livre discutido por Deleuze e Guattari: apropriações de vozes, citações de vozes, vozes dentro de vozes, linhas de fuga diversas em variação contínua, todo o discurso possível em um só discurso, todas as línguas em uma única língua. Um território de experimentação: a glossolalia instaura um espaço-tempo em que a voz procura uma liberação em todos os sentidos, enquanto som, enquanto linguagem.

O que epifonia consegue tocar? O que ela consegue discutir? Trata-se de um recorte que explora uma pequena possibilidade do som na voz. A construção de sentido na quase ausência de significados é uma abertura para sua apreensão enquanto som. A voz desdobra-se indefinidamente numa experiência, que poderia ser a de uma vida. Ela transforma-se, foge, retorna, avança, perde-se. A própria dramaturgia feita de recortes aponta para a multiplicidade de uma enunciação glossolálica: fragmentos desarrazoados do outro e a passagem efêmera do selvagem e desconhecido. Ao tatear uma experiência aleatória, abrem-se os poros para que 
outras vozes possam povoar um devir vocal do performer. Demais, epifonia é um simulacro feito de simulacros, pois a própria operação dramatúrgica busca encerrar uma ficção porosa. A busca de sentido parece desarrazoar a percepção e a experiência.

De qualquer forma, muitas coisas parecem rumorar às orelhas da experiência e, mais importante do que definir o que é epifonia, é na sua potência sugestiva que encontram-se algumas possibilidades de uma vocalidade que tem na glossolalia sua função de desarrazoar e experimentar. Ela requisita o improviso, o rumor, o ruído e o tempo para que uma coisa permita-se transformar em outra, para que o hábito se desaloje, para que um locus se desloque, para que algo seja dito na entrega de estar procurando dizer-se. É como se epifonia procurasse instituir espaços em que a voz possa se jogar a esmo, num estado constante de improvisação, como a própria etimologia dessa palavra requisita: um estado de prontidão e atenção que permita fazer lançar algo à frente. No entanto, este algo é uma substância sonora, um corpo de som, geralmente destituído de palavras, mas inaudito na profusão de seus parâmetros. 


\section{blefarite}

Primeira entrevista concedida por Artaud após sua morte no asilo de Ivry. Recuperando-se de uma pós-morte com um suposto câncer no reto, um tanto esquálido e empoeirado do pó do "ao pó retornarás", Artaud me recebe no limiar de sua covinha, apinhada de cadernos manuscritos, com um humor contagiante e uma língua babélica. A cova é muito pequena, não há como entrar, a princípio tenho que fazer a entrevista do lado de fora. Ele senta-se num pequeno banco de carvalho. Nossa conversa parece atemporal, um bate-papo entremundos, é como se pudéssemos falar de qualquer coisa a partir de qualquer ponto. O Mômo está incandescente.

Eu - O Sr. foi afetado pela ocupação nazista no período de Rodez?

Mômo - A vida dentro de Rodez era uma vida, a vida em si uma outra coisa, a minha vida outra ainda... E parte da vida em Rodez era ocupada por estes soldados desengonçados diante da existência. (Faz um longo silêncio, parecendo rememorar fatos, ora consentindo, ora negando com as feições, cabeça e membros) Me lembro de um dos últimos momentos da ocupação quando eles explodiram a caserna de Burloup, próximo ao asilo. O lugar estava cheio, imagina o cheiro de carne queimada se espalhando dentro do seu quarto. Soldados azerbaijanos assados viciando o ar. Você come carne?

$\mathrm{Eu}$ - Tenho comido peixe.

Mômo - Pequenos peixes batizados em águas doces?

Eu - Também de água salgada... O Sr. é religioso? Quero dizer, se é afeto a liturgias? A morte faz mudar alguma coisa?

Mômo - Não cheiro pior que antes (levanta-se e estende as mãos para que eu possa cheirá-las). Com o tempo você aprende a comer do misticismo alheio para gerar seu próprio misticismo e o religare é sempre um espaço concedido à uma espécie de loucura. (o Mômo retira uma pequena faca do bolso de seu paletó amarrotado, acende uma vela e começa a bater com o lado sem corte da faca em sua própria cabeça, ao mesmo tempo em que murmura coisas indiscerniveis, segue com isso estudando o ritmo e a articulação por cerca de três a quatro horas. Neste meio tempo eu durmo na entrada do recinto e sonho com minha banca de defesa do mestrado e, por algum motivo que eu desconheço, todos presentes estão com as pálpebras inchadas de tanto chorar. Acordo com Artaud lavando meus pés. Estou sentado no banco com os pés para fora da cova). Que tipo de entrevistador é você que dorme no meio da entrevista? (Dá uma gargalhada horrorosa, mas muito divertida).

$\mathrm{Eu}$ - Desculpe-me, eu não sei o que aconteceu... eu...

Mômo - O sono dos justos é tão diferente do sono dos injustos? E o sono dos mortos? Hoje tem entrevista? Tem, sim Senhor! (Ele termina de lavar meus pés e enxuga com alguns jornais velhos, a tinta do jornal parece fresca e as letras e imagens ficam todas borradas, meus pés ficam manchados). 
Eu - Podemos falar um pouco sobre os seus cadernos da época de Rodez? Muitos diriam que o Sr. sofria de graforreia ou grafomania, mas eu os enxergo como uma entidade viva, um espaço multiplicador da vida...

Mômo - Você sabe que eram cadernos escolares, de várias cores, esquadrinhados, quadriculados e com linhas, não é mesmo? Havia uma guerra ali! Um grande circo de horrores fazia a folha sofrer, uma falta de piedade diante das formas...

Eu - Um espaço imaginário?

Mômo - Uma alucinação é real, assim como uma guerra é real. Um limbo povoado de letrinhas, sons e linhas procurando forma... Graforreia é uma palavra horrível!!! (Enquanto explica, ele prepara o que parece ser um chá, adoça e coloca algumas gotas de um líquido cujo vidro ele tira do bolso do paletó). Eu desejava um bestiário cheio de híbridos, uma pré-escrita e uma pós-escrita, desenhar como uma criança desenha... $\mathrm{E}$ as coisas jorravam sem fim nem princípios.

$\mathrm{Eu}$ - O Sr. estava brincando?

Mômo - Sim, acho que ninguém ousaria este termo. Brincar de ser impuro na infantilidade das formas, desaprender. (Oferece-me o chá). Ali eu podia multiplicar, eu podia todas as coisas que um simples caderno sob a ação de um lápis de grafite preto não poderia suportar... uma horda de seres fugiram para povoar meus cadernos... (Tomamos o chá).

Eu - Chamaram seus desenhos e sua escrita de verdadeiras máquinas de guerra.

Mômo - Escrever é preciso, viver não. A magia de fuzilar uma página, depositar algo cru ali, sentir um peso singular devorando com brutalidade as margens, quantos gritos podia-se ouvir ali das bordas? Você está no mundo dos mortos! (Sou tomado por uma vontade incontrolável de chorar. O Mômo, que estava na soleira da porta, entra. Pequenos murmúrios parecem ecoar pelo espaço, que agora parece com uma grande cripta, uma catacumba, com muitas entradas e grutas. Vejo uma imagem da Virgem Negra. Peço desculpas ao Mômo, pois derrubo a xícara vazia que espatifa-se no chão. Isso parece intensificar um rumor. Estou envolto em panos, Artaud me abraça como se fosse uma criança, aconchega-se em meus braços, estou sentado sobre uma pedra que parece um espaço de cerimônias. Faço perguntas sobre a crueldade, sobre a ideia de mártir que dele fazem. Choro com meu filho nos braços. Sou a Virgem Negra e embalo meu rebento. Ele fala sobre sexo, drogas e rock in roll. Cedo o seio. Algo jorra. Dilata-se o tempo).

Mômo - Todos os desejos e histórias poderiam povoar meus cadernos.

Eu - Que som é esse?

Mômo - É uma súplica de um Bufão que perdeu seu Rei. Ele o chama do mundo dos mortos. Ele inventa as palavras para chamá-lo e acredita que sua força o trará de volta. Quase um Godot salmodiando a eternidade naquela esperança que não acaba nunca, nunca...

$\mathrm{Eu}$ - Mas são muitas vozes. 
Mômo - E sabe de uma coisa? Não há rei, nunca houve, tampouco ele é ou fora bufão. Há somente um desejo desmedido de cantar, uma queixa infinda e ininteligível de um moribundo. (Tento pegar os cacos no chão, mas corto o dedo. $O$ Mômo esbarra-se em mim. Procuramos dividir o espaço para continuar a entrevista, mas o espaço é minúsculo. Nos apertamos na cova, ele sai, aguarda que eu me ajeite, ele entra novamente, nos esprememos, eu saio. É como um número de palhaço. Nunca caberíamos naquela cova. Continuo a entre

Do grego blépharon, pálpebra + ite, sufixo que designa inflamação. Também relaciona-se sarcasticamente, aqui, à uma ideia de simulação, um blefe. Trata-se, como epifonia, de um arquivo de áudio de 5'31", gravado e mixado em contexto doméstico a partir de princípios baseados numa vocalidade glossolálica.

Surgiu de improvisos em escalas menores com influência de sonoridades do flamenco e da música árabe. A ideia de um lamento choroso, sofrido e exasperado, com ressonâncias também na ladainha da capoeira, serviu de princípio para uma voz que pudesse ser povoada de animais, uivos lupinos, uma lamúria que pudesse flertar com algo para além do humano na voz. Sua dramaturgia não foi pensada em recortes de fragmentos como em epifonia, antes disso, como simultaneidade de vozes, arquivos inteiros, improvisados sem cortes. Uma voz se relacionava com outra já gravada sob estes mesmos princípios de continuidade e improviso. Em blefarite, uma coletividade está em devir, uma massa sonora rumora e aflui no tempo. Uma coisa não se transforma em outra, ela transforma a si mesma no decurso do tempo, algo que progride na direção de um clímax, evidenciando uma dinâmica das intensidades e a variação acentuada das frequências relacionadas ao contorno melódico. Este clímax é ceifado abruptamente, um valor filosófico da síncope, um corte grosseiro, seco, como uma morte inesperada. O que se faz reverberar ${ }^{119}$ desta violenta cesura?

Diferente de epifonia que se constitui, ainda que de forma mínima, de alguns efeitos e sonoridades que não a voz humana de um único performer, blefarite tem como princípio uma emanação vocal sem disfarces do início ao fim. Não há efeitos, não há instrumentos. $\mathrm{O}$ território do performer é fomentado pelo desejo de emaranhar-se numa vocalidade cujo devir é pura afetação entre vozes. Também não há estúdio, trata-se de uma poética artesanal

\footnotetext{
${ }^{119}$ Segundo Lignelli, a reverberação, como um parâmetro do som, "[...] refere-se à percepção da distância entre a fonte sonora e o receptor, associada ao tamanho e características do espaço em que o som é executado. [...] corresponde ao tempo que um som leva para se dissolver e se perder no ambiente em que produzido" (2014: 234).
} 
engendrada num contexto doméstico, desde o processo de improvisos e ensaios à captação e edição $^{120}$.

Blefarite constitui-se de camadas de vozes emaranhadas e atravessadas umas pelas outras. O contexto das vozes é baseado numa prática relacional por meio de improvisos, o que implica a simultaneidade de uma afetação mútua. Ao mesmo tempo, dois planos parecem agenciar o som, como pode ser visto nas imagens cartográficas das páginas seguintes ${ }^{121}$. Há um plano estático, constante, repetitivo, cujo território é povoado por notas, compassos e uma técnica musical. É um espaço mensurável, recortado, diagramado, que pode ser perscrutado com certa precisão e certa clareza (p. 128). As linhas prescrevem condutas geométricas e orgânicas à maneira de um espaço estriado em Deleuze e Guattari (2005) ${ }^{122}$. Uma emanação desse plano é percebida pela partitura de blefarite (p. 129) que se desdobra dele como uma das muitas possibilidades de segmentação das formas. Trata-se dos dois primeiros compassos que se repetem em looping ao longo do arquivo de áudio. Tal partitura pode ser desvelada no virar da página, fazendo supor um dos estratos da forma e da delimitação desse plano comportado que inclui outros valores além da medida da pauta musical.

Por outro lado, um outro plano parece desarrazoar-se em linhas nômades, em fugas que parecem aleatórias (p. 127). Um plano desmesurado, extático. Essas linhas poderiam configurar desenhos quaisquer, pois é uma potência que virtualiza uma multiplicidade. Elas não começam ou terminam num ponto fixo, embora as cores sugiram percursos de um devir singular. As linhas sinuosas apontam o devir das vozes principais do áudio: a linha preta sugere a voz grave do lamento, voz 1, e a linha magenta sugere a voz aguda, voz 2. As linhas retas sugerem os comentários que agenciam o lamento, a linha verde um comentário que se

\footnotetext{
${ }^{120}$ Foi gravado em seis canais num gravador/reprodutor digital Zoom - H6, com apoio técnico de César Lignelli, que acompanhou todo o processo desde a concepção até o resultado final, entre outubro e dezembro/2014.

${ }^{121}$ A ideia imagética de blefarite foi baseada na partitura de 'Fontana Mix' (1958) de John Cage. Apesar da identidade visual, sua apropriação não procura discutir os conceitos que perpassam a obra de Cage, embora questões como a multiplicidade de sentidos e aspectos difusos confluam para uma noção de potências virtuais que agenciam muitas possibilidades de atualização de uma sonoridade.

${ }^{122}$ Muitas das ideias a respeito dos planos em blefarite parecem agenciar, ao menos possibilitam pontes, com a noção liso e estriado de Deleuze e Guattari, o que implica uma dinâmica entre o que eles chamam de orgânico e abstrato. "O orgânico, com sua simetria, seu contorno, seu fora e seu dentro, se referem ainda às coordenadas retilíneas de um espaço estriado" (2005: 211) e o abstrato seria "Uma linha de direção variável, que não traça qualquer contorno e não delimita forma alguma..." (ibidem: 2013). Apoiado nestas ideias, a reflexão em blefarite é perpassada também por uma noção de plano que, contido e contendo as formas, parece propiciar outro plano, que é aquele que, negando-se a uma coerção daquele plano, busca desarrazoar-se numa matéria fugitiva. Isso faz vibrar uma potência nômade na figura da variação contínua.
} 


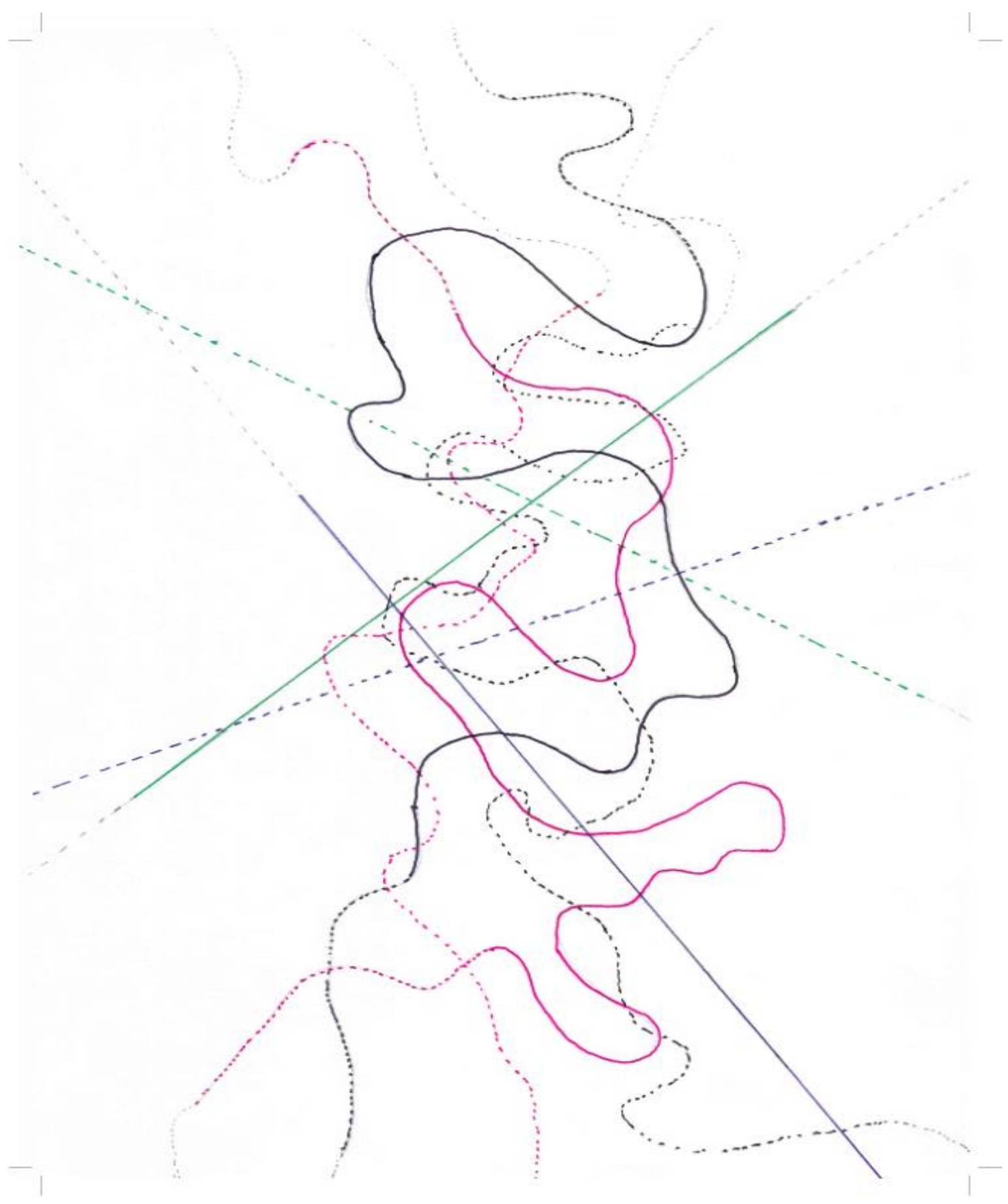




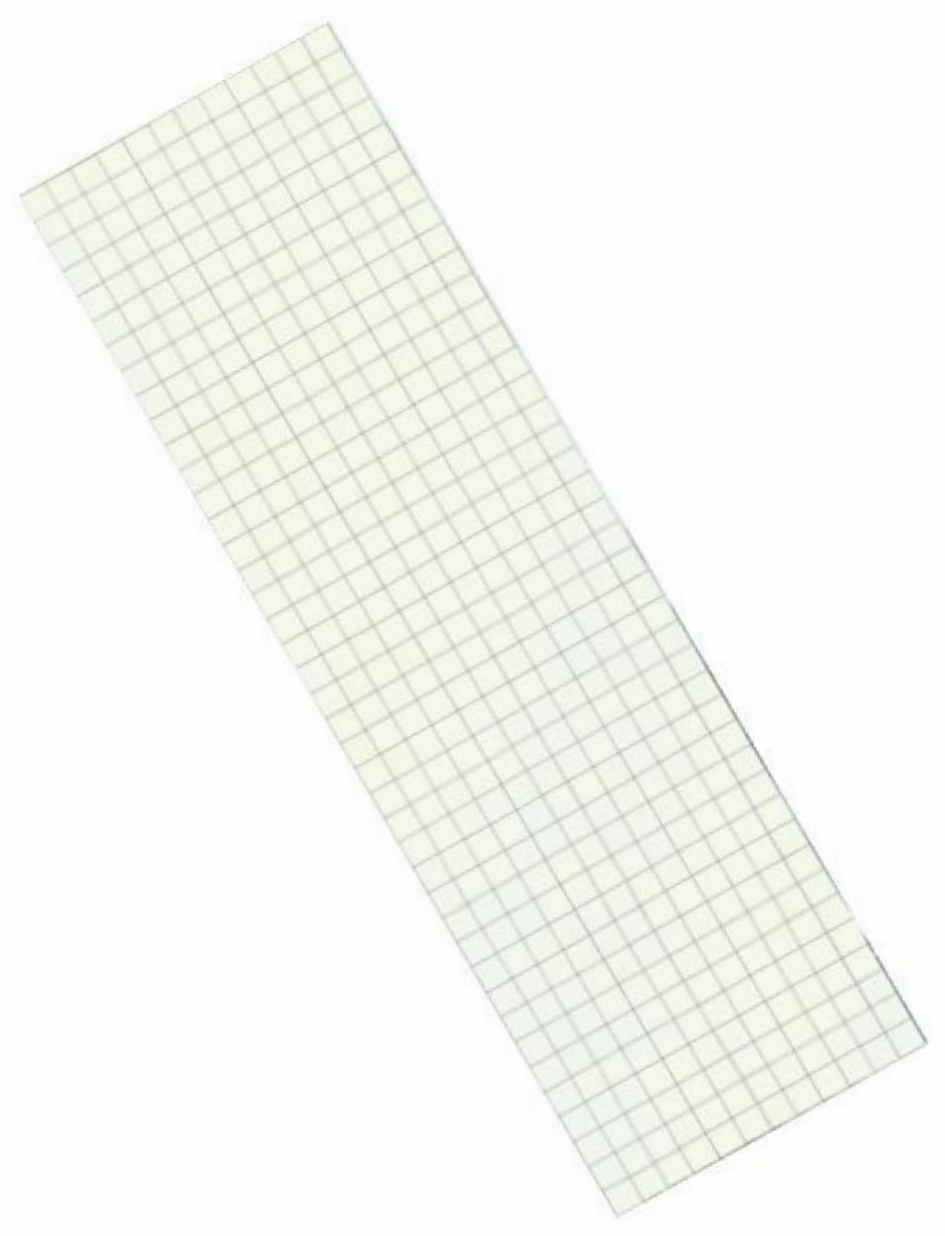




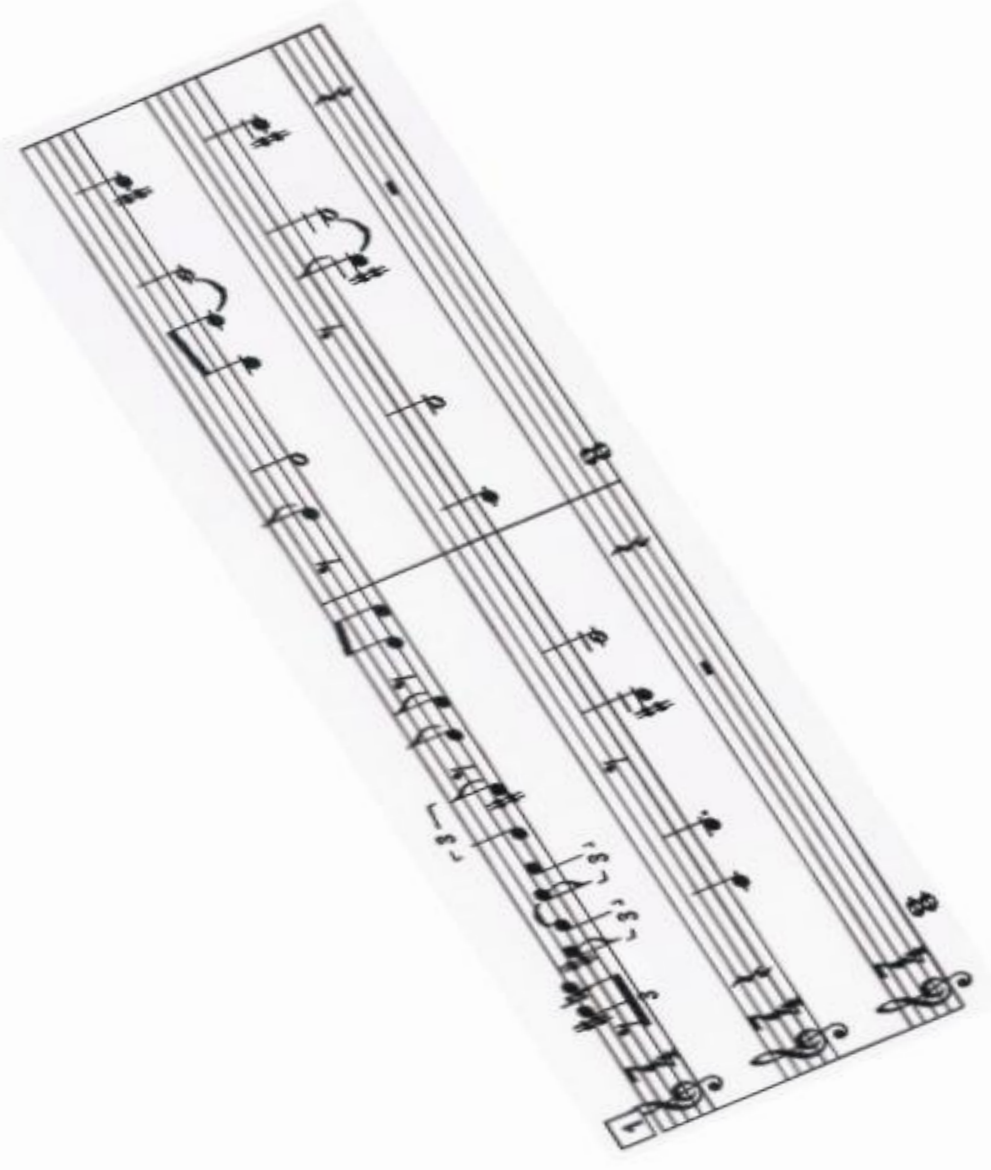


aproxima de um mantra monocórdio, comentário 1, e a linha azul um comentário que parece retirado de um contexto banal e corriqueiro como alguém que fala ao telefone, comentário 2. Ambos os comentários são linguisticamente ininteligíveis. As linhas tracejadas sugerem outros percursos dessas vozes, que poderiam multiplicar-se ao infinito. Seriam potências virtuais das vozes principais e dos comentários. Este plano não evidencia o tempo, tampouco parece dedicar-se à delimitação das formas. Estas linhas, ainda que se evidenciem numa relação com o plano segmentado, têm um tempo próprio, seu minuto pode durar uma era, seu tempo inteiro pode ser instantâneo. São as linhas de variação contínua, a simbiose da voz 1 com a voz 2, que fazem fugir algumas formas, o que teria uma relação mais próxima com a noção do espaço liso, também discutido por Deleuze e Guattari (2005).

Tais linhas diferem-se daquelas que esquadrinham o outro plano, sobretudo por distinguiremse de uma ideia de geométrico e orgânico, o que corrobora com as práticas do corpo sem órgãos inferido por Artaud. Elas soam como desvios que procuram uma proliferação nos entres da estratificação.

Os planos e os espaços interpenetram-se em velocidades que se retroalimentam. As vozes que povoam o plano liberador trazem uma ideia de abstração singular, a linha abstrata da arte nômade, uma linha que marulha outras formas de expressão, cujas fugas abrem-se para uma alteridade animal, para devires não-orgânicos. Diante do poder de organizar infere-se a potência de fazer fugir.

Deleuze e Guattari (2005) inferem que, a despeito de a música ter agenciado sistemas orgânicos e reproduzido sonoridades cujos os territórios delimitavam regras, o som sempre comportou linhas de fuga abstratas em seu espectro vocal, sobretudo por ser uma instância privilegiada que agrega uma multiplicidade de contextos e camadas. Em blefarite, as vozes que se difundem no plano do espaço liso, aberto, ainda que agenciando motivos que poderiam ser vistos como orgânicos como uma ideia de lamento, ou mesmo sua relação com a musicalidade do espaço estático, parecem dar um passo além nas formas de efetuarem o seu desejo. Seus afetos distribuem-se para além do mapa traçado, pois requisitam cartografias mais livres.

As vozes que transitam o plano liberador alimentam-se também do plano esquadrinhado assim como alimentam-se umas das outras. São processos de hibridização por meio de contágios. Um bloco de devir em que efetuam-se vestígios de fórmulas articuladas, alterações 
de parâmetros, afetos e desejos... Interessante notar que tudo aquilo que faz a voz fugir, normalmente tem relação com uma flutuação da matéria no tocante aos parâmetros do som. Mesmo uma simples alteração de frequência pode, dentro de um sistema orgânico estável, colocar tudo a perder-se, onde bem poderíamos dizer fugir-se.

Blefarite passou por muitas incubações e cirurgias ao longo de seu processo. Iniciou-se, de certa forma, no segundo semestre de 2014, num período de treinamento vocal com César Lignelli, cujo princípio era buscar a ampliação do uso dos parâmetros do som, sobretudo frequência, intensidade, ritmo e contorno. Parte do treinamento focou em improvisos em frequências indefinidas, o escorregar da forma mais lenta possível entre as notas, o que levou, por exemplo, a uma aproximação com as sonoridades do canto flamenco ${ }^{123}$. Tais improvisos, baseados em harmonias simples, priorizaram a variação das frequências e, sobretudo, a escuta, pois praticávamos os exercícios em dupla, como num canto com pergunta e resposta ou mesmo como um dueto improvisado com a simultaneidade das duas vozes. Num segundo momento experimentei uma ideia de canto lamentoso numa base harmônica no violão em Am (lá menor) e Em (Mi menor). Importa notar o quão simples é esta harmonia, que se configura como um clichê na música popular em distintos contextos do mundo. Sobre esta base comum fez-se desarrazoar um devir de estranhezas e extrapolações.

A primeira voz captada (voz 1) seguiu esta base harmônica e uma divisão rítmica em 7/4 que foi gravada com a ajuda de um metrônomo, num improviso numa frequência mais baixa (grave). A voz 2, numa frequência mas alta (aguda), foi improvisada sobre a voz captada anteriormente. Ou seja, a liberação dessas duas vozes seguiu a medida musical, tanto na harmonia quanto no andamento de 52/min num compasso 7/4. Posteriormente, o violão foi retirado e a base harmônico-melódica foi criada vocalmente. Esta base, que é repetida ao longo do arquivo de áudio, constitui as vozes da partitura inserida na imagem cartográfica. $\mathrm{O}$ primeiro pentagrama descreve a linha melódica mais aguda, enquanto a mais grave, em contraponto, é descrita no segundo pentagrama. Fechando a grade da partitura, no terceiro pentagrama, faz soar as duas notas dos acordes de Am e Em, com a fundamental e sua terça.

\footnotetext{
${ }^{123}$ A variação das frequências em blefarite investe num uso aleatório de uma noção de coma, que soa como o intervalo mínimo entre uma nota e outra o que implica em múltiplas subdivisões de um tom. Diversas culturas fazem usos distintos das comas, como é o caso da música árabe, da música indiana e da música chinesa. Na música ocidental convencionou-se a divisão de um tom em dois semitons de acordo com a escala temperada, no entanto, esta divisão pode conter subfrações, é o que dá uma impressão de zumbido e imprecisão nas notas em um raga indiano, por exemplo.
} 
As outras duas vozes que cortam o lamento, comentários 1 e 2 , e podem ser vistas na cartografia em azul e verde, foram gravadas cada uma num improviso sem corte e agenciadas no contexto musical. O conjunto das vozes, que inclui a base melódico-harmônica, os comentários e as vozes principais, perfazem o rumor do áudio.

Ou seja, blefarite tem uma base rítmica, num compasso de sete tempos, e segue uma estrutura musical como território para improvisação. É constituída de sete vozes: 1) uma base harmônica, que parte dos acordes de Am e Em, alternando-se a cada sete tempos entre a fundamental lá (A) com sua terça dó (C) e a fundamental mi (E) com sua terça sol (G), ou seja, na cabeça do tempo do compasso de sete entra uma base em Am $(A+C)$, que se faz soar nos primeiros quatro tempos, seguida da entrada de uma base em Em (E+G), que também soa durante os primeiros quatro tempos do compasso; 2) duas melodias fixas, uma mais grave e outra mais aguda que dialogam com a base harmônica, perfazendo uma base melódicoharmônica; 3) duas vozes que soam como comentários do que parece agenciar o lamento: uma voz constante, monocórdia, como um mantra de uma liturgia religiosa e uma outra que soa como alguém que está conversando com outra pessoa por telefone numa língua que não se pode compreender; tais comentários lembram um discurso indireto como num monólogo interior, reminiscências de vozes que parecem interferir no lamento; 4) duas vozes principais, uma numa frequência mais grave e outra numa frequência mais aguda, que improvisam sobre a base harmônica e rítmica; estas vozes são o motivo principal do lamento, elas procuram desarrazoar-se, conflitando entre a música e a linguagem, o canto e a fala, um ritmo e um fora dele, uma afinação e o fora dela, um contexto ou território e aquilo que principia fugir dele. Importante notar que as vozes principais também ganham maior evidência na edição do áudio com o volume dado a elas pós-captação, ou seja, é como um zoom auditivo que as projeta para um primeiro plano.

A ideia de lamento parece dar evidência à relação entre a voz 1 e a voz 2, sobretudo ao devir da voz 2 que mais parece sofrer com os limites e a coerção. A própria forma do lamento, que perfaz um contorno melódico peculiar, pode ser percebida genericamente numa variação de frequências das duas vozes. Enquanto singularidade, a voz grave tateia o território, iniciandose em boca chiusa, fazendo-se perceber aos poucos no meio da massa sonora ao abrir para fonemas em torno de 50". Começa a entoar fórmulas numa linguagem articulada e inventada e aos poucos vai estabelecendo seus espaços. Em torno de 1'40" a voz grave, que até então permanecia num conjunto de frequências estáveis, começa a explorar um registro um pouco 
mais agudo, ao mesmo tempo em que investe numa articulação mais clara numa espécie de melopeia falada, fazendo ataques numa relação direta com a voz mais aguda. Em torno de 3'40 a voz grave, que já situou-se enquanto presença e território de explorações sonoras, estabiliza-se para emanação da voz mais aguda. Em torno de 5'05" a voz grave retorna com mais ênfase e intensidade, num timbre mais rasgado até a explosão que é cortada em 5'31". A dinâmica das intensidades também se alia às variações de frequência para a instituição da presença de tal voz, pois nos momentos de assertividade e ataques, a intensidade e a frequência parecem tornar mais evidente o sensorial na matéria dessa voz.

A voz aguda também começa em boca chiusa, como um rumor imperceptível em microinterferências na sua relação com a voz grave. Vai se precipitando em pequenos comentários, crescendo para um lamento mais evidente, choroso, com pequenas súplicas e melopeias de uma voz sofrida, numa relação direta com a voz grave. A voz aguda cresce com a assertividade articulada da voz grave, o conjunto das frequências passa de um rumor e pequenas intermitências à uma alusão mais direta ao lamento em escalas mais indefinidas. A isso acompanha-se gradualmente um aumento de intensidade. A voz aguda também tateou seu território e agora ganha evidência. Seu discurso lamentoso, povoado de lamúrias, gritos e choros estabelece sua presença na relação com a voz grave. O espectro de suas frequências tem um foco peculiar a partir de 3'58", tão como o da dinâmica da intensidade. A partir daí as duas vozes estão empoderadas dos parâmetros que as singularizam: a voz 1 com sua frequência mais grave, seu timbre mais escuro, seu poder de articulação e maior assertividade e a voz 2 com seu registro mais agudo, impreciso nas frequências, vacilante nos impropérios de seu lamento, num timbre mais nasalado e metálico.

Em 4'33" a voz aguda se apropria da articulação da voz grave e começa a entoar suas fórmulas e daí em diante a relação entre as duas progride numa simbiose, cuja intensidade e o aumento das frequências transbordam num clímax que sofre um corte abrupto. Tal corte, na relação com a síncope como comentado em epifonia, induz a um impacto sensorial daquilo que, irrompendo com certa violência e também ceifado com tal violência, faz algo transbordar no vazio, um vazio cuja reverberação do áudio faz povoar de uma presença nos espaços abertos pela escuta. Um afeto parece ecoar num espaço em que algo derramou-se todo. Importa notar a forma como o parâmetro reverberação se faz presente neste corte em blefarite, sobretudo pelo áudio não ser evidenciado no contexto de um lugar determinado, pois a noção desse parâmetro implica um som que é percebido no espaço e tal espacialidade é vislumbrada no 
áudio como algo virtual, ou mesmo um espaço conceitual que faz povoar a percepção, algo que reverbera e ressignifica a apreensão de sentido, projetando um rumor. Ou seja, o corte, cuja manobra possibilita que algo possa afluir, intenta prolongar uma algaravia, ela parece ultrapassar a duração de 5'31".

Ao longo do processo de experimentação em blefarite, níveis estranhos de exploração de limites foram evidenciados como afetos à improvisação e pertinentes à ideia do áudio como uma extrapolação pertinente ao devir das vozes, a exemplo do excesso de ruídos, também da voz aguda que em vários momentos quebra numa mudança de ressonância ${ }^{124}$ como em 4'14"4'18" ou mesmo uma distorção que se evidencia em torno de 5'12, pois na confluência de uma frequência aguda com o aumento de intensidade fez desarrazoar a captação do áudio. Estes ruídos diversos, que nem sempre foram intencionais, acabaram por fazer parte do conjunto de blefarite, justamente por pactuar com uma poética glossolálica que também faz emanar restos, excessos e sujeiras diversas em sua estética. A própria ideia de que as duas vozes principais parecem confinadas a uma estrutura musical mesmo que dissonante, é o que as libera para uma grosseria sonora. Aspectos mais brutos e ruidosos têm passagem na voz do performer ao pactuar nas bordas de uma vocalidade. Dessa forma, as estruturas melódica, harmônica e rítmica são transbordadas e, por isso, a liberdade das linhas na transparência da imagem cartográfica que agenciam um plano desarrazoado.

Se em epifonia o silêncio parecia onipresente, em blefarite o ruído ${ }^{125}$ se estabelece como um parâmetro constante. A configuração melódica suscita a ideia de um coro rumoroso que corrobora com uma estrutura ruidosa. Demais, o ruído também se relaciona com as dissonâncias, com os descontroles e, sobretudo, com uma noção de insuportabilidade de alguns limites, a exemplo de uma voz cujas notas parecem querer evadir de uma afinação marcada pelo estrato musical, assim como os desarranjos citados acima. As fugas das vozes

\footnotetext{
${ }^{124}$ De acordo com Lignelli (2014), a ressonância privilegia determinadas faixas de frequência de acordo com as propriedades físicas dos ressonadores o que, no caso da voz, resulta na caracterização de atributos tímbricos como uma voz 'metálica', 'escura' ou 'nasalada'. É comum dizer que a voz quebra quando há uma mudança de ressonância o que reflete uma mudança de timbre, como por exemplo o que se convencionou chamar de passagem da voz de peito para voz de cabeça e vice-versa.

${ }_{125}$ Assim como em relação ao silêncio, Lignelli comenta a relatividade e subjetividade inerentes à percepção do ruído enquanto valor e sentido culturais, discutindo uma relação complexa entre sons desejados e indesejados, tão como musicais e não-musicais. Aponta também sua importância no contexto estético da performance, pois "[...] podem auxiliar na criatividade e na ampliação de camadas de sentido. São capazes de agir como uma espécie de desorganizadores de clichês, provocadores de novos estilos e até de possíveis entre gêneros artísticos" (102: 2014).
} 
principais, uma em relação a outra, e as duas em relação ao todo realçam 'o' fora dos territórios, um aquém e um além que incita a variação contínua de desejos e a proliferação de afetos.

Assim como em epifonia, uma noção de ruído e de silêncio enquanto parâmetros para a voz em performance relacionam-se antes de mais nada à percepção e produção de sentidos diante de outros parâmetros. Se naquela os ruídos pareciam imersos no silêncio cujo vazio parecia abarcá-los, em blefarite o silêncio pode ser escutado como percepções invasivas à uma zoada murmurante, ele instala-se circunstancialmente nas brechas entre os parâmetros. Entre as tramas das vozes que interpenetram-se, há passagens, vácuos cuja percepção propicia escutar um som ou outro com mais evidência. Ou seja, o silêncio escorre entre os outros parâmetros.Numa resposta da voz aguda a um ataque da voz grave ou na diminuição da intensidade, pode-se instaurar uma vaga que é aberta pela escuta. Soam como pausas conceituais.

Retomando ao contorno melódico em blefarite, ao lado das silhuetas das vozes principais, que sofrem mutações no tempo do áudio, apoiando-se em melodias erráticas de um lamento cuja relação passional explora limites de frequência, existem os contornos fixos e repetitivos como a base melódica e harmônica, assim como contornos relativamente estáveis como as vozes que funcionam como comentários, ruídos e fibrilações que atravessam o lamento, ou seja, o mantra que parece uma entoação litúrgica, quase como uma salmodia numa língua ininteligível, com uma frequência mais estável e, aquilo que fazendo-se soar também numa linguagem desconhecida, faz lembrar uma fala mais cotidiana, respostas de estímulos de um diálogo, cujos ruídos de uma conversação como risos, afirmações em boca chiusa, onomatopeias e aliterações povoam e formam tal contorno, numa variação mais ou menos estável das frequências.

Como as vozes preenchem o tempo em blefarite? Uma noção rítmica é perpassada pela maior presença ou ausência das vozes principais. A despeito do ritmo do plano segmentado em 7/4, uma percepção rítmica é afetada pela presença da voz aguda e da voz grave no tempo. À medida que elas se tornam mais evidentes ao preencherem os espaços é como se um outro ritmo interferisse no ritmo geral, fazendo o tempo avançar e encurtar. Esta evidência que atravessa todo o áudio, fica mais explícita, por exemplo, a partir do 5', o que também vem corroborar com a reverberação após o corte inesperado, pois o aumento de intensidade e a 
variação das frequências que alteram a percepção rítmica fazem lançar o som que se precipita para além do corte súbito.

Os ciclos e as repetições são elementos que em epifonia incitam eternos retornos, reelaborações e reconfigurações no tempo, enquanto que em blefarite, esses aspectos perfazem um plano fixo em looping com a base melódica e harmônica possibilitando a multiplicação de camadas, algo como uma topologia sonora de um território murmurante. A repetição, nesse caso, é um plano em que o desejo instaura fugas e intensidades, ou seja, é a partir da estabilidade que as vozes conflitam. Um conflito entre as formas e um 'fora' delas, um fora da linguagem, um fora da música, um fora do humano, um fora das linhas, um fora dos planos. Vários improvisos 'simultâneos' para um mesmo bloco de tempo. O que cresce em blefarite é sempre uma legião, um coletivo marulhoso, um coro de camadas multiperspectivadas. Um bloco intenso de vozes é lançado como uma matilha que sai em debandada. Uma simultaneidade está sempre escapulindo faíscas, lamúrias, excessos, e vozes procurando fugir. 


\section{abracadabra}

Eis aqui uma fronteira, também um limiar. Lugar de travessias e pactos. O que se passa entre abracadabras e o que se derrama para além destas bordas? Ao tatear aquilo que, parecendo absolutamente inóspito, exige, ou mesmo inspira, uma escuta, que é uma entrega, ainda uma aceitação de riscos, torna-se possível uma abertura. Sugerimos práticas e percursos, revisitamos Artaud e projetamos cartografias que intentam uma expansão das forças do desejo, sobretudo de um desejo de tomar e ser tomado por uma vocalidade: entregar-se ao desconhecido, ao outro, ao estranho, enfim, embrenhar-se em glossolalias.

Uma cartografia vocal soa efêmera em Artaud, seus contornos são contingentes e algo principia sempre a reverberar algo, desdobrando-se em camadas e camadas, pois sua obra sugere uma porosidade instigante às vicissitudes do som da voz. Nela, nada parece declarado, seguro, palpável, explícito, soa antes como ruídos obscuros e possibilidades abertas de entregas intensivas. Nele, uma glossolalia procurou povoar uma vocalidade. Faz ressonar Artaud aquilo que inspira uma pulsão vital na criação e, no contexto da voz em performance, faz dissolver uma noção de linguagem para fazê-la afluir como sonoridade e matéria no corpo da voz. Desaprender a dizer importa uma gagueira genuína, uma utopia vocal, um não-lugar, um entre mundos. Uma glossolalia supõe, em Artaud, uma multiplicação de valores relacionados à voz que confluem à criação de um corpo sem órgãos. Dessa forma, pode-se vislumbrar em sua obra um conjunto de valores filosóficos e poéticos que sugerem práticas para uma possível vocalidade.

Os contextos glossolálicos podem permear uma noção de voz, fazendo marulhar as ressonâncias entre uma filosofia do desejo e as práticas estético-experimentais da performance contemporânea. O que pode a voz em perfomance num pacto com o diabo? Ou melhor dizendo, numa sucessão possível de pactos com o diabo? Isso implica as passagens de outros na prática do performer, ou seja, uma coletividade faz-se passar em sua voz, numa profusão de diferenças e singularidades. O 'eu' seria uma dissolução na experiência glossolálica, o que faz soar uma multiplicação de outros nas possibilidades da alteridade. Uma voz assim requisita chafurdar-se na instabilidade da linguagem e do discurso, suscitando uma variação contínua, um constante reconfigurar-se como som e sentido. Macular-se nas impurezas do outro. 
Como recorte de práticas cartográficas, epifonia e blefarite agenciam estes valores, perfazendo relações entre os conceitos aqui tratados e uma poética sugerida por esta noção de voz. Também sugerem percursos e formas para se tatear o som da voz por meio de improvisos, apoiando-se numa palpabilidade evidenciada pela apropriação e variação dos parâmetros do som. Da mesma forma, o corpo dessa pesquisa vem agenciar aberturas e possíveis linhas de fuga para a voz. Suas possibilidades virtuais derramam-se para aquém e além de estruturas mais estáveis de várias práticas vocais, pois faz cartografar intensidades que atravessam territórios, cuja instabilidade incita uma experimentação contínua. O performer singularizando devires.

Princípios de uma técnica nômade: prontidão para sempre fazer um pacto com o diabo. Dessa forma, acredito que no percurso cartográfico desta pesquisa, mais abriu-se e sugeriu-se sobre as possibilidades de uma vocalidade glossolálica do que delimitou-se ou estabilizou-se princípios, o que aponta para algo muitas vezes indiscernível, lacunar, ininteligível, que povoa terrenos movediços. Ao mesmo tempo há pontes em relação ao terreno da estética e da performance, cujas zonas embaçadas de uma voz potencial são prenhes de aspectos que podem ser úteis ao ator e ao performer. É o caso de uma porosidade factível em sua prática vocal, suscetível a interferências capazes de desarrazoar sua criação, o que implica uma escuta que afeta sua percepção e produção a partir de contextos mais lacunares e obscuros, o que pode permitir e instigar uma flexibilização diante de formas institucionalizadas do vocalizar, possibilitando uma ampliação de técnica e repertório.

A própria ideia do glossololalium é um intento de fazer proliferar, no sentido de uma errância nômade, certa irregularidade e multiplicidade de conteúdos que povoam os territórios da voz em performance. Nesse caso, o glossololalium é uma fenda que invoca conjecturas diversas com muitas áreas do conhecimento como estudos míticos e simbólicos, religiosos, linguísticos, psiquiátricos, literários, artísticos, que vêm corroborar com experiências cênico-performáticas. Demais, há uma lacuna em relação às publicações que dão foco a uma noção de glossolalia voltada para a performance vocal, sobretudo em língua portuguesa. A maior parte das publicações relacionam-se a aspectos religiosos e psiquiátricos, assim como à área da comunicação e da linguística.

Esta lacuna parece supor uma lacuna prática, que permitiria ao ator e performer o reconhecimento de instâncias pouco palatáveis de uma vocalidade possível, a exemplo de uma 
ininteligibilidade discursivo-linguística, ruídos, excessos e restos, e percursos amorais, cujo desafio diante do risco de se colocar aberto a sonoridades estranhas, pode suscitar e desdobrar-se numa literatura sobre o tema. Percebe-se também que a noção de uma vocalidade glossolálica é ampla, marulhosa, múltipla, não há como sedimentá-la, antes, busca-se afetos a favor de seus devires singulares. Também é uma noção que intenta instaurar-se nas flutuações de outros territórios, apropriando-se de outras vocalidades, nos entres de outras práticas, como um recurso desarrazoador. Dessa forma, quando falamos de uma voz de princípios glossolálicos, não se trata de um movimento que exclui aspectos mais estáveis de uma vocalidade como é o caso da língua, da palavra e do texto, mas daquilo que, inclusive se apropriando dessas instâncias, pode ser engendrado também entre esses estratos, promovendo um movimento de variação contínua em prol de uma multiplicação de diferenças.

Entendemos que um conjunto de práticas que envolvem a criação de um corpo sem órgãos para uma noção de voz aqui sugerida tem na glossolalia um princípio agenciador de sua experimentação. Esta pesquisa optou por recortes e cartografias permeáveis e reconfiguráveis deixando de fora várias experiências que incluem a palavra e a língua como base para improvisações. A exemplo de uma prática experimentada por mim, entre outras, inominada ainda e em constante mutação, mas que lembra uma forma muito mais sofisticada de supercazzolla e que intenta uma desestabilização do discurso por meio do improviso. Esta prática pode ser realizada em muitos contextos da performance e constitui-se de um discurso que parece plausível, coeso, coerente, claro, apresentável, mas que de fato não diz nada. Ele parece flutuar entre intenções diversas, contextos variados, principiando sempre uma fuga, no entanto, procurando a atenção do ouvinte e tentando envolvê-lo em elucubrações e pontos de vista que se desdobram ao infinito. Diferente de uma conversa sem sentido em que os termos são usados com certa aleatoriedade, tal prática prima pela intenção de fazer parecer ter sentido, ainda que ele não exista de forma determinada.

Demais, a escuta de sonoridades díspares em contextos humanos e cósmicos, como sons do reino animal, os sons das línguas e dialetos mundo afora, sons vocais de crianças em fases que antecedem a apreensão de uma língua, liturgias estranhas em diversos contextos míticoreligiosos, referências da poesia e da música, sons da morte de uma estrela, de uma imensa geleira trincando e tudo aquilo que, por meio do som, venha tornar possível o contágio de uma vocalidade para a cena, também fez parte das práticas que presumem uma voz desarrazoada. 
Diante desse conjunto de práticas potenciais que procuram desarrazoar discursos, sentidos e significados linguísticos, há uma conexão inerente à escuta, à percepção e produção de sentido por meio do som vocal evidenciado nessa pesquisa, o que corrobora com as práticas estéticas aqui realizadas, pois elas vêm agregar os valores que foram revolvidos durante todo o processo de investigação de tal vocalidade. Aqui, soa importante também para o performer a apropriação dos parâmetros do som no contexto da voz em performance no intento de tornar palpável sonoridades estranhas. Ou seja, infere-se uma noção que se debruça sobre aspectos sensoriais da voz, voltada para uma materialidade de seus recursos. Uma noção de parâmetros do som agregada a uma noção de glossolalia pode multiplicar as possibilidades de uma autonomia criativa na performance vocal.

Esta experimentação da voz que não cessa e que se movimenta a partir de instabilidades, não se prende a um incessante flutuar e desequilibrar-se, assim como não é afeito àquilo que almeja uma estabilidade, antes disso ela promove zonas de intensidades entre contextos. Por isso as cartografias cambiantes e as errâncias nos territórios. Como maquinar dentro destes territórios a exemplo de uma possibilidade vocal na profusão da escrita e desenhos de Artaud no contexto de seus cadernos em Rodez? Máquinas de guerra são incubadas, alimentando as margens, bordejando, buscando alianças: uma voz está sempre à espreita. Um uso ou função singular em relação a isto ou aquilo é o princípio do devir. Um devir que alimenta a voz em experiências limiares. É uma necessidade vital de um limite ao qual não se pode chegar.

A glossolalia enquanto um conjunto de práticas enunciativas importa ao ator ou ao performer enquanto possibilidade de se jogar com as sonoridades na voz. Sobretudo jogar com os sons que povoam ideias limítrofes e obscuras de uma vocalidade que reporta aos entres de territórios vocais. Dessa forma, vislumbrando cartografias no contexto da performance, encontra-se na obra de Artaud toda uma sugestão sonoro-poético-conceitual para tal vocalidade ao inferir a importância de uma materialidade do som da voz cujo investimento de desejo é lançado sobre os muitos suportes da criação vocal: a linguagem, o corpo, a própria escrita, e a vida em seus múltiplos contextos de enunciações apropriáveis pela performance.

A prática de uma tal vocalidade possibilita também um outro olhar do performer e do ator sobre o texto, a palavra e a fala, ao vislumbrar estas instâncias como contextos vastos de sonoridades possíveis, de valores que não se voltam necessariamente para os significados e sentidos estabelecidos. Gaguejar numa vocalidade que se apropria do texto e da língua para 
usos desviantes, sincopados, ao engendrar potências acústicas em territórios inexplorados. Abocanhar o que parece inóspito e insólito demais para ser digerido. Também soa desafiador e instigante para o performer tatear a experiência de uma incompreensão inaudita ao improvisar com uma matéria muitas vezes inominável, mas que se pode tocar e enveredar por entre. Apropriar-se dos parâmetros do som e fazer cirurgias e experiências com eles, possibilitar frankensteins sonoros e deixar que outras vozes venham povoar seu devir na peformance.

Ao lado de uma experiência que flerta com valores de um 'fora' e 'entres' das potencialidades da voz, de uma possível reapropriação do texto e da palavra falada, de um conjunto de valores acústicos que podem ser redimensionados pelos parâmetros do som, de aspectos desarrazoados que acompanham a produção e apreensão de sentidos pela emissão vocal, a glossolalia também almeja um espaço para reverberar, ela também abraça a matéria do mundo, também suscita os corpos em performance e é dessa maneira que os desdobramentos dessa pesquisa apontam para valores sinestésicos de uma experiência glossolálica. A glossolalia e o movimento, a glossolalia e a visualidade do corpo, a glossolalia e o espaço, a glossolalia e o outro... Embora tenha-se comentado pouco sobre a importância da escuta para apreensão de valores glossolálicos numa vocalidade, este aspecto que pode ser de intensa porosidade, aponta uma alteridade cuja potência pode proporcionar muitos valores para a prática do ator e do performer. A própria glossolalia implica um outro que necessita ser escutado sem preconceitos, também um outro que pode falar em você.

De forma a me desafiar é que vislumbro outros territórios de experimentação para uma glossolalia performática. Como esta vocalidade glossolálica efetua-se nos corpos e afeta o espaço? Quais são as possibilidades de espacialização de suas sonoridades? Assim, me volto para as perspectivas de investigação do espaço da performance, pois a experiência de tal noção de glossolalia implica afetar todo o complexo envolvimento da cena. Ou seja, se a voz é um fenômeno multiperspectivado da cena e da performance, fazendo confluir um corpo, um espaço de enunciação, possivelmente um outro e um conjunto de práticas que envolve a criação, também valores e conceitos que permeiam uma poética e uma efetuação de desejos, me soa instigante pesquisar as relações viáveis de uma glossolalia que perpasse o movimento, a atuação, a escuta, uma corporeidade e uma técnica possível. Percebe-se, assim, as várias alternativas de desdobramentos de uma glossolalia na investigação criativa do performer ou ator. 
A própria obra de Artaud suscita uma investigação sinestésica do som. Consequentemente, a voz, sugere-se numa miríade de suportes que permitem inferir esta sinestesia, a exemplo de uma imagem que inspira um som, uma sonoridade que impacta num corpo, uma escrita que vibra e requisita uma voz, uma voz que sugere espaços e formas e todo um devir que singulariza esta experiência de valores sensoriais. A glossolalia e os sentidos.

Vibra aqui as possibilidades de novos pactos, pois algo inquieta-se, algo almeja alastrar-se em territórios de novas pesquisas, uma voz licorosa parece embeber o desejo, marulhando estranhos chamados, bizarras cantigas, que fazem ressoar núpcias com o diabo. 


\section{referências}

\section{bibliográficas}

ARISTÓTELES. Poética. Lisboa: Imprensa Nacional - Casa da Moeda, 1994.

ARTAUD, Antonin. Histoire vécue d'Artaud-Mômo. Paris: Fata Morgana; Gallimard, 2009. . Eu, Antonin Artaud. Lisboa: Assírio \& Alvim, 2007. . Van Gogh, O suicida da sociedade. Rio de Janeiro: José Olympio, 2007. . El arte y la muerte / Otros escritos. Buenos Aires: Caja Negra, 2005. . Oeuvres. Paris: Quarto Gallimard, 2004. . 50 Dessins pour assassiner la magie. Paris: Gallimard, 2004. . Os Tarahumaras. Lisboa: Relógio D'água, 2000. . O Teatro e seu Duplo. São Paulo: Martins Fontes, 1999. . Linguagem e vida. São Paulo: Perspectiva, 1995. . Mexico y Viaje al Pais de los Tarahumaras. México: Coleccion Popular, 1992. . Heliogábalo ou O Anarquista Coroado. Lisboa: Assírio \& Alvim, 1991. . O Pesa-Nervos. Lisboa: Hiena Editora, 1991.

. Para acabar de vez com o juízo de Deus, seguido de O Teatro da Crueldade. Lisboa: \&etc, 1975.

BELY, Andrei. Glossolalia: A poem about sound. New York: Pforte Verlag, 2003.

BLAKE, William. Poesia e prosa selecionadas. São Paulo: Nova Alexandria, 1993.

BONDÍA, Jorge Larossa. Tremores - Escritos sobre a experiência. Belo Horizonte: Autêntica, 2014.

Notas sobre a experiência e o saber de experiência. Revista Brasileira de Educação. № 19, pp. 20-28, São Paulo, 2002.

BUENO, Silveira. Grande dicionário etimológico prosódico da língua portuguesa. São Paulo: Saraiva, 1968.

BURGESS, Anthony. Laranja Mecânica. São Paulo: Aleph, 2004.

BURKE, Peter e PORTER, Roy. Línguas e Jargões: Contribuições para uma história social da linguagem. São Paulo: UNESP, 1997.

CAVARERO, Adriana. Vozes Plurais - Filosofia da expressão vocal. Belo Horizonte: Editora UFMG, 2011.

CARLSON, Marvin. Performance - Uma introdução crítica. Belo Horizonte: Editora UFMG, 2010.

CERTEAU, Michel de. La Fable Mystique, XVI-XVII siècle II. Paris: Gallimard, 2013. A Invenção do Cotidiano. São Paulo: Editora Vozes, 2011. 
CHION, Michel. A audiovisão - Som e imagem no cinema. Lisboa: Edições Texto \& Grafia, 2008.

COURTINE, Jean-Jacques. Les silences de la voix. Langages, 91, 1988, pág. 7-25.

DAVINI, Silvia Adriana. Cartografias de la voz en el Teatro Contemporaneo: El caso de Buenos Aires a Fines del Siglo XX. Universidad Nacional de Quilmes: Ed. Bernal, 2007.

DELEUZE, Gilles. Nietzsche. Lisboa: Edições 70, 2009.

Diferença e Repetição. São Paulo: Graal, 2009.

Crítica e Clínica. São Paulo: Ed. 34, 2004.

DELEUZE, Gilles e GUATTARI, Felix. Mil Platôs - Capitalismo \& Esquizofrenia. Volumes 1, 2, 3, 4 e 5. São Paulo: 34, 1988.

. O Anti-Édipo. São Paulo: 34, 2011.

. O que é filosofia? São Paulo: 34, 2004.

DERRIDA, Jacques. A escritura e a diferença. São Paulo: Perspectiva, 2011.

Artaud le Moma: interjections d'appel. Paris: Galilée, 2002.

O animal que logo sou. São Paulo: UNESP, 2002.

. Che cos'è la poesia?. Inimigo Rumor, Rio de Janeiro, nº 10, p. 113-116, 2001.

DERRIDA, Jacques e BERGSTEIN, Lena. Enlouquecer o Subjétil. São Paulo: UNESP; Ateliê Editorial; Imprensa Oficial/SP, 1998.

DUMOULIÉ, Camille. Artaud, la vie. Paris: Desjonquères, 2003.

FO, Dario. Manual mínimo do ator. Franca Rame (Org.). São Paulo: Senac, 1997.

FOUCAULT, Michel. Estética: Literatura e Pintura, Música e Cinema. Rio de Janeiro: Grupo Editorial Nacional e Forense Universitária, 2013.

HAOULI, Janele El. Demetrio Stratos - Em busca da voz-música. Londrina: J. E. Halouli, 2002.

HOFMANNSTHAL, Hugo von. Una Carta (De Lord Philip Chandos a Sir Francis Bacon). Valencia: Pre-Textos, 2008.

HOPPIN, Richard. H. La Música Medieval. Madrid: Akal Ediciones, 2002.

HOUAISS, Antônio. Grande Dicionário Houaiss da língua portuguesa. Rio de Janeiro: Objetiva, 2008.

JAEGER, Werner. Paidéia, A Formação do Homem Grego. São Paulo: Martins Fontes, 2003.

JÚNIOR, Antônio Wellington de Oliveira. Glossolalia: Voz e Poesia. São Paulo: EDUC; FAPESP; Omni, 2004.

KHLÉBNIKOV, Velimir. Ka. São Paulo: Perspectiva, 1977.

LÉVY, Pierre. O que é o virtual?. São Paulo: Ed. 34, 2011.

LIGNELLI, César. Sons E $(m)$ Cena - Parâmetros do som. Brasília: Ed. Dulcina, 2014.

LOW, Albert. A vaca de ferro do zen. Porto Alegre: Bodigaya, 1997.

MÈREDIEU, Florence. Eis Antonin Artaud. São Paulo: Perspectiva, 2011. 
MINARELLI, Enzo. As razões da voz - Entrevistas com protagonistas da poesia sonora no séxulo XX. Londrina: Eduel, 2014.

MOISÉS, Massaud. Dicionário de termos literários. São Paulo: Cultrix, 1997.

MORFEE, Adrian. Antonin Artaud's Writing Bodies. New York: Oxford University Press, 2005.

NIETZSCHE, Friedrich. Assim falou Zaratustra. São Paulo: Companhia das Letras, 2014.

NOLETTO, Israel. Glossopoese - O Complexo e Desconhecido Mundo das Línguas Artificiais. São Paulo: Biblioteca 24 horas, 2011.

NOVARINA, Valère. Teatro para os ouvidos. Rio de Janeiro: 7Letras, 2011.

POUND, Ezra. ABC da Literatura. São Paulo: Editora Cultrix, 2012.

POZZO, Alessandra. La Glossolalie en Occident. Paris: Les Belles Lettres, 2013.

Grrr...grammelot. Parlare senza parole. Dai primi balbettii al grammelot di Dario Fo. Bologna: CLUEB, 1998.

PREVEL, Jacques. En compagnie d'Antonin Artaud. Paris: Flammarion, 1994.

RODRÍGUEZ, Ángel. A dimensão sonora da linguagem audiovisual. São Paulo: Senac, 2006.

ROLNIK, Suely. Cartografia Sentimental: transformações contemporâneas do desejo. Porto Alegre: UFRGS, 2007.

ROOB, Alexander. El Museo Hermético - Alquimia \& Mística. Madri: Taschen, 2005.

ROSA, Guimarães. Grande Sertão: Veredas. Rio de Janeiro: Nova Fronteira, 2006.

SÓFOCLES. A Trilogia Tebana - Tragédia Grega, Vol. I. Rio de Janeiro: Jorge Zahar Editor, 2001.

SONTAG, Susan. Sob o signo de saturno. Porto Alegre: L\&PM Editores, 1986.

SPOLIN, Viola. Improvisação para o teatro. São Paulo: Perspectiva, 2001.

SWIMME, Brian. O universo é um dragão verde. São Paulo: Cultrix, 1995.

VIARO, Mário Eduardo. A torre de Babel. Língua portuguesa, São Paulo, ano 9, no 100, p. 48-51, 2014.

ZIZEK, Slavoj. La voz en la diferencia sexual. In La voz, vários autores, p. 47-70, Colección Orientación Lacaniana, Série Testimonios y Conferencias, número 2, Buenos Aires, Argentina, 1997.

ZUMTHOR, Paul. Introdução à Poesia Oral. Belo Horizonte: UFMG, 2010.

Performance, recepção, leitura. São Paulo: CosacNaify, 2007.

\section{audiovisuais}

ANNAUD, Jean-Jacques. A guerra do fogo. Lume Filmes, 2009.

BERGMAN, Ingmar. A hora do lobo. Versátil Home Vídeo, 2008.

D'ONOFRIO, Regia Luciano; AFFATATO, Mônica. La Voce Stratos. Feltrinelli Real Cinema, 2009. 
MORDILLAT, Gérard; PRIEUR, Jérome. La véritable histoire d'Artaud le Mômo et En compagnie d'Antonin Artaud. Arte Vídeo, 2005.

MONICELLI, Mário. Meus Caros Amigos. Platina/Visocopy.

\section{discografia citada}

ARTAUD, Antonin. Pour en finir avec le jugement de dieu. Sub rosa, 1995.

BERIO, Luciano. Laborintus 2. Harmonia Mundi, 2000.

Sequenzas III \& VII, Différences, Due pezzi, Chamber music. Newt on classics, 2011.

STRATOS, Demetrio. Cantare la voce. Cramps Records, 1978.

. Demetrio Stratos: Em busca da voz música. CD que acompanha o livro de Janete El Haouli.

Okkulte Stimmen - Mediale Musik, Recordings of unseen Intelligences 1905-2007 (3 AudioCDs), Berlim: Supposé, 2007.

\section{sites consultados}

https://www.youtube.com/watch?v=8A4n9Ez9O8g em 22/02/2015. http://www.ipla.com.br/estudos/trabalhos.html em 06/01/2015. http://www.youtube.com/watch?v=QpWZ0x3x5G8 em 29/12/2014. http://www.demetriostratos.org, consultado em 25/12/2014. https://www.youtube.com/watch?v=MxqnjjFpMXU em 07/12/2014. http://www.collinsdictionary.com, consultado em 24/04/2014. http://www.oxforddictionaries.com/us/, consultado em 24/04/2014. http://www.etymonline.com, consultado em 24/04/2014. http://www.con-versiones.com/nota0810.htm em 17/02/2014. http://www.youtube.com/watch?v=G6nGSNI--qU em 03/03/2014. http://www.youtube.com/watch?v=y0YKmrbeTic em 17/03/2014. http://www.youtube.com/watch?v=6kxIWWW1_GQ em 04/04/2014. http://www.youtube.com/watch?v=82m9fhoQi2o em 04/04/2014. http://www.egs.edu/faculty/jacques-derrida/articles/las-voces-de-artaud/ em 24/04/2014. http://htl.linguist.univ-paris-diderot.fr/biennale/et06/texte\%20intervenant/pdf/courtine.pdf em 17/02/2014. 